\title{
PREENCHIMENTO DA DECLARAÇÃO DE ÓBITO: FALTA DE INFORMAÇÃO?
}

Maria Elizabeth da Silva Hernandes Corrêa

São Paulo

*2002* 


\section{PREENCHIMENTO DA DECLARAÇÃO DE ÓBITO: FALTA DE INFORMAÇÃO?}

\section{Maria Elizabeth da Silva Hernandes Corrêa}

Tese apresentada ao Departamento de Epidemiologia da Faculdade de Saúde Pública da Universidade de São Paulo para obtenção do título de Doutor em Saúde - Pública

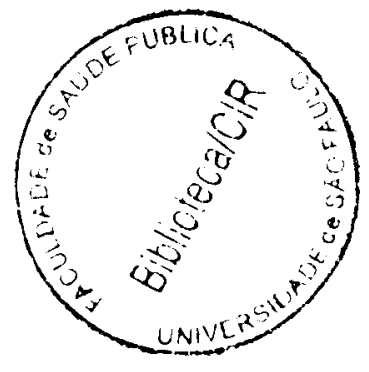

Prof. Dr. Ruy Laurenti

Orientador 
Autorizo, exclusivamente para fins acadêmicos e científicos, a reprodução total ou parcial desta tese, por processos fotocopiados.

Maria Elizabeth da Silva Hernandes Corrêa :

08 de novembro de 2002 


\section{Ao Lucas e a Juliana}

pelo aprendizado de gerar vida....

\section{Ao Júlio}

pelo aprendizado do compartilhar ....

\section{Ao meu pai}

pelo aprendizado do desapego...... 


\section{AGRADECIMENTOS :}

Como é importante terminar um trabalho e perceber que devemos o mesmo a tantas pessoas, tantas.... que muitas vezes fica difícil citar todas elas. Mas gostaria de me lembrar, senão de todas, pelo menos as que me acompanharam mais de perto nesta jornada.

No trabalho de dissertação do mestrado senti um enorme vazio ao conceber e realizar o trabalho de campo praticamente sozinha, apesar de estar vinculada ao departamento de saúde coletiva.

Hoje termino este trabalho tendo a convicção que fazer junto é a melhor forma de se construir o conhecimento, falo isto pois tive a felicidade, de parte do trabalho de campo, realizar em conjunto com a Profa. Maria Cristina Baggio, pois as nossas teses teriam um tronco comum. No início pareceu estranho aos nossos orientadores, mas eles perceberam o avanço que este tipo de procedimento traria e concordaram com a empreitada. Por isso agradeço à Profa. Sabina e ao Prof. ${ }^{\circ}$ Ruy, meu orientador, que mostraram mais uma vez que são pessoas que tem uma visão ampliada do processo de conhecimento, que não se atém a normas estanques e emburrecedoras, mas são capazes de ousar, não é por acaso que o reconhecimento que eles têm no meio científico, extrapola a área que transitam.

Esta fase do trabalho foi extremamente rica, muitas discussões, idéias compartilhadas... construídas e reconstruidas, conhecimento produzido...Desta forma agradeço a esta companheira de trabalho a oportunidade que me deu de vivenciar com ela este processo.

Neste período de elaboração da tese, muitas coisas aconteceram na minha vida, a saída dos meus filhos de casa. Uma perda? Não, um ganho de vêlos alçando vôos sob o nosso olhar atento, mas os deixando ir...Agradeço imensamente ao Lucas e a Juliana, pela chance de refazer conceitos, renovar continuamente o meu instinto de observação e aprimorar as minhas intuições.

De novo outra separação, esta um pouco mais dolorida pela impossibilidade de vê-lo por perto, quando bem entendesse ou necessitasse... a doença e morte de meu pai. Mas com certeza o acompanhamento desse 
processo foi muito importante para a minha vida e para o entendimento deste trabalho. Sendo assim, eu mais uma vez agradeço a ele a oportunidade de mais um aprendizado, entre tantos que ele me deu em sua vida terrena. Estes agradecimentos se estendem a minha mãe que me fez tomar gosto pelos estudos e pelas criaturas e com despojamento nos possibilitou a vivência do processo de separação.

Em todas as etapas importantes de elaboração de qualquer estudo científico que eu realizei na minha carreira docente, pude contar com uma colega de departamento que lia criteriosamente os trabalhos e contribuía com a discussão sob a ótica racional e amorosa. Hoje, infelizmente, para mim, não posso recorrer a ela, ficou um vazio... pois mais que uma colega de trabalho era uma amiga, uma irmã, que não está mais entre nós. E mais uma vez agradeço a Profa. Marisa Pastori que apesar de não ter podido ler este trabalho, contribuiu com sua realização me incentivando a escrevê-lo, e mais do que isto me dando a oportunidade de acompanhar a sua trajetória de vida, a sua garra, a sua alegria, a sua veia crítica... mantida até o final dos seus dias neste mundo.

Muito a agradecer a Profa . Maria Cecília Cordeiro Dellatorre, que além de amiga e comadre, me auxiliou com as referências bibliográficas, me apoiando com sua leitura criteriosa e olhar culto e abrangente do mundo.

Agradeço a Profa. Cassandra Luchesi Dias, Profa. Marilda Siriani de Oliveira, Prof. ${ }^{\circ}$ Antônio Carlos Ribeiro, docentes da disciplina de saúde - coletiva e epidemiologia que, além de apoio moral e afetivo, deram conta das atividades que me cabiam.

Não poderia esquecer da Profa. Cássia, coordenadora da Unidade de Habilidades em Comunicação, pela sua compreensão em relação ao meu pedido de afastamento.

O meu apreço, também, ao Dr. Ênio Sevilha Duarte, atual secretario de saúde do município que entendeu o processo final deste trabalho.

Devo muitos e muitos agradecimentos à Marcia e Cidinha do Setor de Aprimoramento e da Angela da Secretaria da pós - graduação, da Faculdade de Saúde Pública, pelo empenho, competência e disponibilidade que facilitaram sobejamente o meu trabalho, vencendo as barreiras burocráticas que por vezes me pareciam intransponiveis. Não poderia esquecer da Miriam, fiel escudeira do 
Profo Ruy, mas que extrapolou a sua função e me ajudou nos momentos difíceis que enfrentei neste percurso.

Agradeço ainda, ao Prof Paulo Marcondes que colocou em minhas mãos um programa de computador que facilitou sobremaneira a digitação das entrevistas que realizei.

O meu apreço às bibliotecárias Regina, Helena e Josefina que estavam sempre prontas a me ajudarem a conseguir as referências o mais rapidamente possivel.

Ao Prof. Fernando o meu reconhecimento, por ter me ensinado o valor e a potencialidade dos estudos qualitativos, primeiro através de seus escritos, depois com sua enorme paciência e simplicidade de quem já decodificou o conhecimento e não precisa se esconder atrás das palavras difíceis e dos marcos teóricos ininteligíveis.

A minha familia distante geograficamente, que participou comigo nas diferentes fases do trabalho, sempre foi um alento e um estímulo.

Por fim, mas não menos importante, fico devendo mais uma ao Júlio, meu companheiro de tantos anos, que vem me ensinando continuamente a importância da vida, com seu respeito pelas pessoas doentes que estão sob seus cuidados, me fazendo crer que é possível ser melhor médico do que se é atualmente, me estimulando a voarmos juntos porém, mantendo a nossa independência. 


\section{RESUMO}

INTRODUÇÃO : A declaração de óbito (DO) sofre interferência da organização de sistemas de informações em saúde, de mortalidade em particular, e da qualidade do seu preenchimento. Quanto a este último item, a maioria dos trabalhos analisa a qualidade das informações da DO, pouco discutindo a relação entre estas e os médicos que a preenchem.

OBJETIVO: Avaliar os campos que compõem a DO, bem como, os fatores que interferem na qualidade do preenchimento deste instrumento, junto aos médicos.

METODOLOGIA: Primeira fase: análise quantitativa do preenchimento da DO das pessoas que morreram no periodo de agosto a dezembro de 1999 em Marília. Estas foram classificadas em: GRUPO I - causa básica bem definida, GRUPO II - causas básicas mal definidas e residuais de capitulo, GRUPO III- mortes por causas externas, GRUPO IV- mortes em mulheres de 10 a 49 anos, e GRUPO V- Mortes por causa presumivel de aids; em todos estes avaliaram-se os campos da DO segundo o proposto por Fonseca e Laurenti. Na Segunda fase, realizou-se uma pesquisa qualitativa, utilizando um roteiro semi - estruturado, aplicado aos 25 médicos que mais assinaram declarações de óbito no período estudado. Todos assinaram o Termo de Consentimento Esclarecido. As entrevistas foram gravadas e organizadas segundo as expressões chave, idéia central e discurso do sujeito coletivo (DSC) ${ }^{(44)}$.

RESULTADOS: Avaliaram-se 534 DO. As do GRUPO I (355) foram 334 incompletas e destas 202 tinham seqüência lógica definida, em $84 \%$ a escolaridade estava em branco, nos óbitos fetais e menores de um ano, os campos referentes à mãe que estavam em branco em maiores proporções foram: escolaridade - $53,8 \%$ e ocupação - $30,8 \%$. Daquelas pertencentes ao GRUPO II (104 - 19,1\%), 100\% apresentaram causa básica mal definida, 79 eram incompletas e $84 \%$ das com causas básicas classificadas em residuais de capítulo (25) também. Ao comparar o item assistência médica entre o GRUPO I e II, a diferença foi estatisticamente significativa (Qui - quadrado $=20,41$ $p<0,001)$. No GRUPO III $(48-8,8 \%)$, os itens 43 e 44 da DO estavam em branco em $55 \%, 5 \%$ apresentavam atestados completos e $88,7 \%$ as causas estavam corretas. Nas causas externas (GRUPO IV - 20-3,6\%) 14,6\% das DO não foram assinadas pelo Instituto Médico Legal, $100 \%$ estavam incompletas e $88,7 \%$ eram corretas. No GRUPO V (17- 3,1\%) a maioria dos campos estava bem preenchida e, em um caso, o diagnóstico foi incorreto. Na pesquisa qualitativa, os 25 médicos foram entrevistados, de cada uma das perguntas, elaboraram-se, pelo menos, 2 instrumentos de análise de discurso (IAD) e seus respectivos DSC. A partir desses vislumbrou-se a relação que os médicos têm com: a morte, o medo de preencher um documento legal, a sua inserção no trabalho, o entendimento das finalidades da DO e do seu aprendizado para preenchê-la.

CONCLUSÃO : De uma maneira geral as DO são bem preenchidas em Marilia, mas ainda há vários atestados de óbito com causas mal definidas (14,5\%). Além disso, campos importantes para estudos clínicos e epidemiológicos ficam em branco, como é o caso da escolaridade e do tempo decorrido entre o diagnóstico e a morte. Pelos DSC percebeu -se que há médicos com dificuldade para preencher este instrumento pois este ato passa pelas dificuldades intemas e da organização do próprio trabalho.

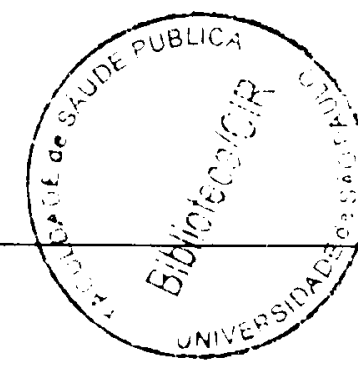




\section{ABSTRACT}

INTRODUCTION: The death certificates (DC) suffer the interference of the organization of the system of health information and the mortality in particular; and the quality of its fulfillment. Relating to the last item, most of the works analyzes the quality of the information of DC without discussing the relationship among them and the methods used by the physicians that fill it.

OBJECTIVE: To evaluate the blanks that composes the DC as well as the factors that influence the quality of the fulfillment of this instrument, to the physicians .

METHODOLOGY: First phase: quantitative analysis of the fulfillment of DC of persons that died from August to December of 1999 in Marilia - State of São Paulo, Brazil. They were classified in GROUP I - the underlying cause was very well defined, GROUP II - the underlying cause was ill defined or classified as residual of chapters, GROUP III - external death causes, GROUP IV- deaths of women between 10 and 49 year old, and GROUP V-presumably deaths caused by Aids. In all of these cases the evaluation was done in all the DC fields according to Fonseca and Laurenti proposal. In the second phase a qualitative research was made by using a semi - structured rout, applied to the 25 physicians that signed most death certificates, during the study period. All of them signed the illustrious consent term. The interviews were recorded according to the expressions- key, main - idea and collective subjects speeches (CSS).

RESULTS: 534 DC were evaluated. The GROUP I (355) presented 335 incomplete and 202 of them had a defined logical sequence, $84 \%$ the variable education was not fulfilled; in the fetal deaths and children under the age1, the fields referring to the mothers that were in blank in most of the cases were: education - 53.8\% and occupation - 30.8\%. In GROUP \|I (104- 22.3\%), $100 \%$ of the DC that presented a ill defined cause (79) were considered as incomplete and $84 \%$ of the DC with a underlying cause classified as a residual were incomplete (25) too. Comparing the item medical assistance among GROUP I and II, the difference was statistically significant (Chi-square $20.41 \mathrm{p}<0,001$ ). In GROUP III (48-97\%), the items 43 and 44 were not fulfilled in $55 \%$ of the DC, $5 \%$ presented complete certificates and in $88.7 \%$ the causes were correct. In the external causes (GROUP IV- $20-4,2 \%$ ) 14.6\% of DC were signed by Forensic Institute physicians, $100 \%$ were incomplete and $88,7 \%$ were correct. In the qualitative research, the 25 physicians were interviewed, for each question, it was elaborated, at least, 2 instruments of speech analysis (AID) and respective DSS. From those question was shimmered the relationship that the physicians have with: the death, the fear of filling a legal document, its role in the work, the comprehension of the purposes of $\mathrm{DC}$ and the learning to fill it.

CONCLUSION: In general way the DC are well filled in Marilia, but still there are many death certificates with ill defined causes (14.5\%). Besides, important fields for clinical and epidemiological studies are not fulfilled, as education and the time. From DSS it was noticed that there are difficult to fill this instrument because this act goes by the internal difficulties and the organization of their own work 


\section{APRESENTAÇÃO}

"A morte é o gênio inspirador, ou a musa da filosofia... Sem a morte, seria mesmo difícil que se tivesse filosofado". São com estas palavras que Schopenhauer inicia o texto "Da morte e sua relação com a indestrutibilidade do nosso ser - em si" (1844). E, pedindo licença ao grande filósofo, vou parafraseálo e dizer que a epidemiologia também deve muito à morte. Muitos estudos têm sido realizados utilizando os dados de mortalidade; os diagnósticos de saúde, ainda, se sustentam nos indicadores construidos a partir das informaçōes de morte.

Desde a dissertação de mestrado e estudos posteriores que realizei, a morte foi o objeto central em muitos deles.

Ao buscar a raiz deste interesse, encontro, inicialmente, a minha dificuldade em lidar com a morte. A considerava como a maior violência que o ser humano poderia sofrer. Mas com o passar dos anos, o amadurecimento, estudos, enfim... esta idéia foi se modificando e por incrível que pareça passei a viver a vida de melhor forma.

Mas ficou uma indignação, ao me deparar com pessoas que foram desrespeitadas antes ou no momento da morte, porisso o interesse pelo tema continua, agora sob um novo olhar.

Hoje me "agrada" trabalhar com a morte, pois continua me fazendo pensar na vida e sempre, pelo menos, sob dois ângulos: na vida de quem já viveu e na minha própria existência. Quando penso nas pessoas que "viraram papéis sem nome", que utilizamos nos nossos estudos, avalio que no período entre o seu nascimento e a morte elas devem ter sido importantes para suas famílias e/ou amigos e que na finitude material continuam sendo fundamentais, nos auxiliando, mostrando através de seus dados o que de melhor podemos fazer para quem vive ou viverá, neste mundo.

Nas análises de prontuário que já realizei nas minhas atividades profissionais, principalmente nos estudos de pessoas que vieram a morrer, as perguntas bailavam na minha cabeça o tempo todo... Porque o médico preencheu o atestado desta forma ? As informações estavam aqui.... Porque este doente esteve no serviço pelo menos duas vezes na semana que 
antecedeu a morte e ninguém percebeu? ....Será que ele não sabe preencher?... Será que as aulas de atestado de óbito que nós demos na graduação foram suficientes? Será ...? Porque?....

Eram tantos porquês e "será(s)" que resolvi que quanto à minha própria vida, entre outras coisas, devia contribuir com alguns elementos para a categoria que faço parte, a dos médicos - tantas vezes vis, mas, muitas vezes, vítimas- na realização do seu trabalho. Para isto abordo uma atividade que faz parte do cotidiano do médico, de alguns mais e de outros menos, depende da área de atuação, que é preencher uma Declaração de Óbito. 


\section{ÍNDICE}

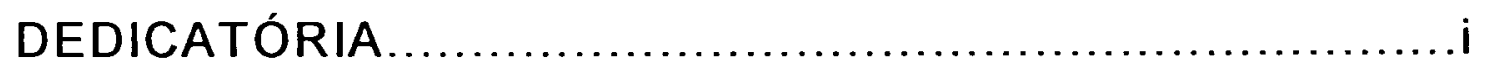

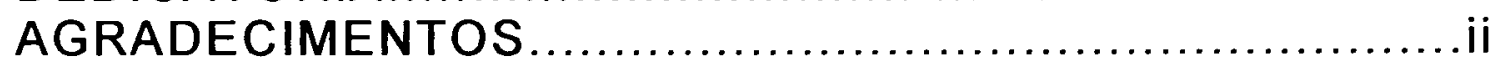

RESUMO ....................................................

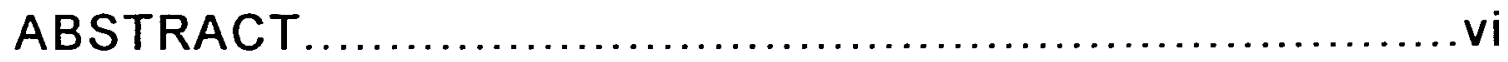

APRESENTAÇÃO ........................................... vii

I.INTRODUÇÃO .......................................................

I.1.DECLARAÇÃO DE ÓBITO E A ESTATÍSTICA VITAL ...................... 2

1.2 DECLARAÇÃO DE ÓBITO E A CLASSIFICAÇÃO DE DOENÇAS...............9

1.3.SISTEMA DE INFORMAÇÃO EM SAÚDE E SISTEMA DE INFORMAÇÃO EM

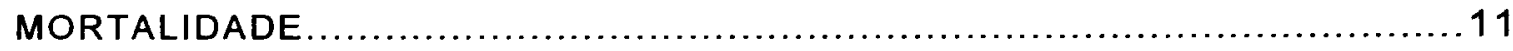

1.4. QUALIDADE DA INFORMAÇÃO E A DECLARAÇÃO DE ÓBITO ..............13

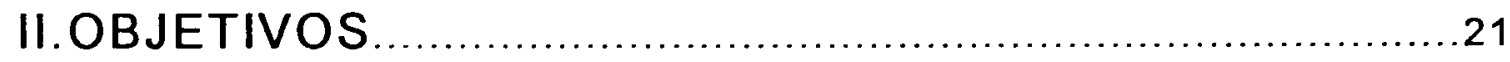

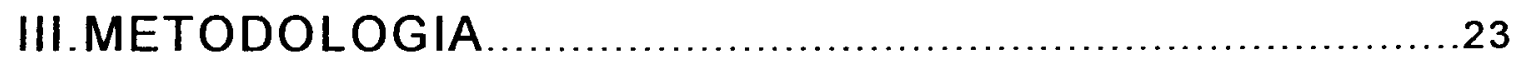

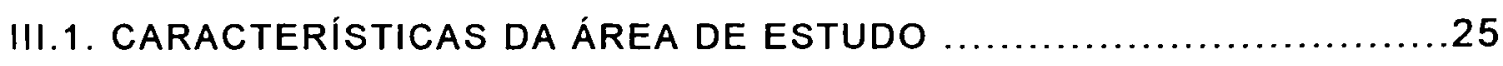

III.2. PRIMEIRA FASE : AVALIAÇÃO QUANTITATIVA .......................25

III.3.SEGUNDA FASE: AVALIAÇÃO QUALITATIVA ............................28

IV. RESULTADOS E DISCUSSÃO .....................................

IV.1.PRIMEIRA FASE: AVALIAÇÃO QUANTITATIVA ............................

IV.2.SEGUNDA FASE: AVALIAÇÃO QUALITATIVA ...........................53

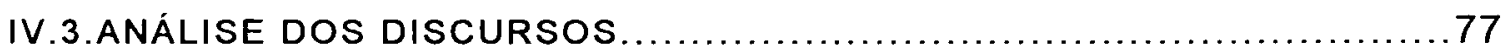

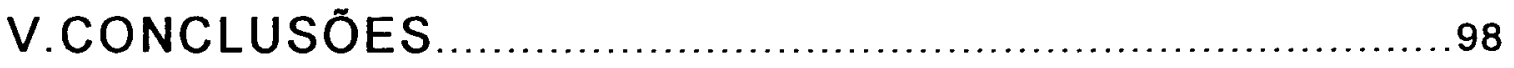

VI.CONSIDERAÇÕES FINAIS .......................................105

VII. REFERÊNCIAS BIBLIOGRÁFICAS ..........................112

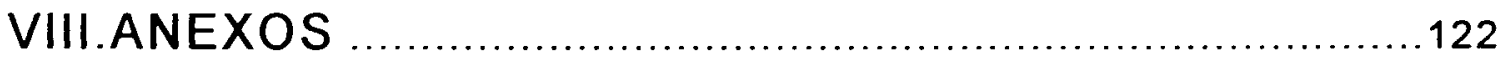




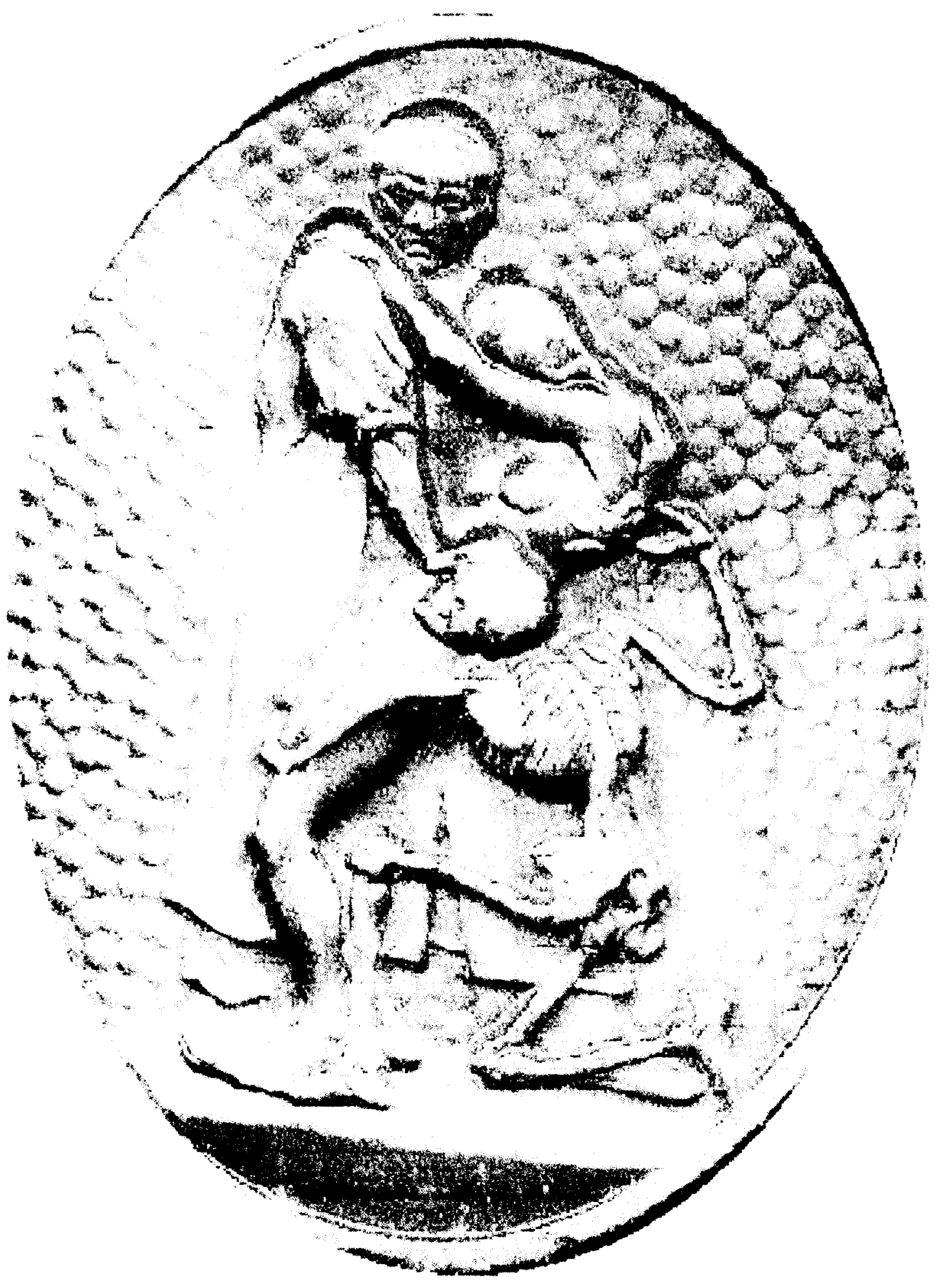




\section{I - INTRODUÇÃO:}


A necessidade legal de uma Declaração de Óbito (DO), assinada por um médico, tem implicaçōes nem sempre explícitas, à primeira vista. São fatores que passam pela evolução histórica da exigência deste documento e sobretudo pela formação técnica e profissional do médico responsável pelo respectivo preenchimento. Tal como se conhece hoje, a DO é um instrumento composto de nove blocos de informaçōes, quais sejam : I - relativo ao cartório, II - identificação da pessoa que morreu, III - dados residenciais, IV- dados do local de ocorrência da morte, $\mathrm{V}$ - itens para morte fetal ou de menor de 1 ano, $\mathrm{VI}$ - condições e causas de óbito, VII - informações e assinatura do médico que preencheu o atestado, VIII - informações para mortes por causas externas e IX-para mortes sem assistência médica. Cada um destes campos de informações é composto por itens, em números variados, cujo total chega a 62 (Anexo I) ${ }^{(14)}$.

O bloco VI é composto por 7 campos de dados e o item 49 é o que trata, especificamente, das causas que levaram à morte e compõe-se de duas partes : Parte I: com quatro linhas, sendo que na última deve constar a causa básica de morte, e Parte II, com duas linhas, reservadas para as causas contribuintes.

Este instrumento foi construído ao longo da história das populaçōes e sua origem está profundamente ligada à constituição da estatística vital, como uma área de conhecimento, e à elaboração da Classificação Internacional de Doenças. Outros elementos também interferem na estruturação da DO, entre eles, a organização de sistemas de informações em saúde em geral e em mortalidade em particular, e a qualidade do preenchimento deste instrumento.

\section{I.1. A DECLARAÇÃO DE ÓBITO E A ESTATÍSTICA VITAL}

Enumerarem as pessoas de uma comunidade era uma prática comum desde os primórdios dos tempos. Os fins geralmente eram administrativos, políticos e econômicos, como no caso da Grécia e Roma antigas. Os sistemas utilizados para esta contagem eram diversos para os diferentes povos. Por 
exemplo, os Incas, no Peru, segundo Mello Jorge, citando Prescott, utilizavam "nós em cordões coloridos"; todavia, a finalidade era a mesma (57).

Os objetivos de se enumerarem nascimentos e mortes foram se alterando ao longo da história. Com o desenvolvimento do trabalho industrial, na Europa do século XVI e XVII, o Estado sentiu necessidade de ter maior controle sobre a população de trabalhadores, inclusive passando a se preocupar com as mortes prematuras a que este grupo poderia estar submetido ${ }^{(92,93)}$.

Outro fator decisivo para a evolução de uma área de conhecimento que possibilitasse uma maior compreensão das populações foi a percepção dos cientistas da época (que eram principalmente matemáticos) de que a natureza se comportava segundo uma "ordem e uma regularidade", possibilitando um questionamento quanto ao comportamento da sociedade. Se esta também apresentasse "ordem" e "regularidade", seria possível a aplicação de leis matemáticas para melhor compreendê-la ${ }^{(92)}$.

Neste contexto, Petty, médico e economista, cria a aritmética política, uma disciplina que possibilitava conhecer dados em relação à população, bem como de suas doenças, entre outros. Com esta disciplina, propõe também o uso de Listas de Mortalidade para o cálculo de médicos necessários para a Inglaterra ${ }^{(92,93)}$.

A grande contribuição para o estudo dos problemas de saúde do ponto de vista quantitativo foi dada por Graunt (1620 - 1674), na obra "Natural and political observations mentioned in a following index, and made upon the Bills of Mortality", publicada em 1662. Neste trabalho, enumerou 83 causas de mortes, a partir das listas de mortalidade produzidas semanalmente pelas paróquias da cidade de Londres ${ }^{(114)}$.

Assim, demonstrou o que os matemáticos já haviam percebido na natureza: que os eventos vitais apresentavam certa regularidade, tais como o nascimento de maior número de homens em relação ao de mulheres. Também chamou atenção para o fato de que havia maior número de mortes nas cidades do que no campo. Além disso, já neste período, apontou para a necessidade de se obterem dados de boa qualidade, embora ressaltasse que mesmo dados "imperfeitos" podiam resultar em informações "úteis" ${ }^{(92,93)}$. 
No final do século XVIII, vários países da Europa criaram leis que obrigavam os órgãos e ou igrejas a registrarem nascimentos, casamentos $\theta$ mortes e a elaborarem, periodicamente, listas de mortalidade. Estas leis foram inspiradas no movimento de polícia médica, que nasceu na Alemanha, com Frank (1748-1821) e Mai (1742-1814), que abordavam, entre muitas outras coisas, a importância da estatística vital, para entender o comportamento das populaçōes, bem como suas doenças, com o objetivo de manter e promover saúde ${ }^{(92,93)}$.

Em 1749, Achenwall propôs que o nome "aritmética política" fosse substituído por "estatistica". A questão que se colocava era: como verificar quantitativamente que os ambientes de vida e de trabalho estavam correlacionados com a saúde das pessoas?

Mas foi Farr, médico inglês, que, segundo Mello Jorge ${ }^{(57)}$, mostrou a finalidade epidemiológica de se estudarem nascimentos e mortes.

Todos estes movimentos, que estavam ocorrendo na Europa, alcançaram a América, principalmente os Estados Unidos, onde as epidemias eram um grande problema e o governo buscava os conhecimentos médicos, para debelá-las. Em 1804, criou-se o cargo de Inspetor Sanitário da Cidade; que se constituía em um "ramo do Departamento de Polícia" e atuava, entre outras coisas, na coleta de estatística vital. Em 1853, foi aprovada uma lei que regulava o registro de nascimentos, casamentos e mortes ${ }^{(92)}$.

Em 1847, quando a Associação Médica Americana foi fundada, criou-se um Comitê de Higiene, que passou a realizar inquéritos sanitários e a estabelecer um método para consolidar e analisar as estatísticas vitais.

No Brasil, desde a descoberta, início do século XVI, se reproduzia o que na época se passava em Portugal ${ }^{(53)}$

Prado Jr, em seu livro Formação do Brasil Contemporâneo ${ }^{(70)}$, coloca que "as estatísticas demográficas que possuímos da colônia são extremamente escassas". Os levantamentos tinham objetivos bem definidos, a saber: eclesiásticos e militares, portanto apresentavam uma finalidade seletiva e só se interessavam em recensear parte da população ${ }^{\left({ }^{82)}\right.}$. 
No final do século XVII, a febre amarela era um grande problema brasileiro. No Tratado Único da Constituição Pestilencial de Pernambuco, de autoria de Ferreira Rosa, publicado em Lisboa, que estudou esta epidemia entre 1685 e 1695, pode-se notar que o governador de Pernambuco lançou uma campanha de combate à doença, traçando alguns pontos básicos para a cidade. Entre estas medidas, o controle do "morto e da morte", através de uma certidão do médico ou do cirurgião que cuidou do paciente ${ }^{(53)}$. Mas esta campanha teve um caráter muito limitado, do ponto de vista geográfico.

No final do século XVIII, parece que a metrópole começa a se preocupar com a "organização de estatísticas gerais e sistemáticas". Há uma encomenda do governo central, para o então governador da Paraíba, Fernando Delgado de Castilho (e que serviu de modelo a uma circular que foi enviada para todos os governadores da colônia), que solicita e orienta que os dados de nascimentos, casamentos e mortes, ocupações, comércio e preços, sejam colhidos anualmente. Este recenseamento parece ter sido realizado pelo menos uma vez, mas seus resultados, como diz Prado Jr, "possivelmente dormem ainda o sono dos arquivos em Portugal" (82).

Em 1829, os médicos se organizaram e fundaram a Sociedade de Medicina e Cirurgia do Rio de Janeiro, cujos objetivos eram a higiene pública e a defesa da ciência médica. Em relação ao primeiro ponto, a Sociedade criou comissões permanentes. Uma delas, a Comissão de Moléstias Reinantes, organizou as primeiras tabelas demográfico-sanitárias e os primeiros quadros necrológicos. É a estatística médica registrando não só a vida mas a própria morte ${ }^{(53)}$.

A Comissão de Salubridade Geral, em 1830, elaborou um relatório que discutia a falta de registros civis, o fato de se enterrarem os mortos nas igrejas, a falta de médicos que verificassem as mortes etc. Apoiada neste documento, a Câmara Municipal do Rio de Janeiro aprovou em 1932 um Código de Posturas, que prescrevia a necessidade de se ter um documento que atestasse o óbito, fornecido pelo médico, para fins de sepultamento ${ }^{(53)}$.

Em 1851, o governo imperial expediu um regulamento que criava um registro civil nacional. Esta medida vinha ao encontro da necessidade de se 
estimular a migração estrangeira para o trabalho. Como a atividade de registro era realizada pela igreja, os estrangeiros que não eram católicos tinham dificuldade de conseguir atestados de óbito e certidões de batismos. Mas o governo recuou, em virtude de uma grande revolta dos padres, que não queriam perder as rendas auferidas por esta atividade, ficando esta reforma cartorária adiada até 1888 e sendo concluída na República ${ }^{(86)}$.

Para coordenar o combate às epidemias que continuavam castigando a população brasileira, particularmente a de febre amarela de 1849 no Rio de janeiro, que resultou em 4 mil mortos, o Ministério do Império nomeou uma Comissão Central de Saúde Pública. A cidade foi dividida em paróquias e, destas, em distritos. Criaram-se Comissões Paroquiais de Saúde Pública, que tinham como uma das tarefas elaborar as estatísticas de mortes que seriam encaminhadas para a Comissão Central (21).

O uso da estatística vital para o entendimento da ocorrência das doenças e possivel intervenção passa a fazer parte do cotidiano dos médicos brasileiros, no final do século XIX. Para corroborar este fato, Sigaud, em um discurso realizado na Sociedade de Medicina do Rio de Janeiro, reconheceu a transformação do objeto da prática médica, elegendo a estatística como o instrumento que possibilitará o estudo da população. Esta visão proporcionou o desenvolvimento de alguns trabalhos que utilizavam análise demográfica, tais como o de Alcântara Machado e de Rezende sobre suicídio no Rio de Janeiro. Nestes estudos os autores já faziam considerações a respeito da dificuldade de se trabalhar com esta fonte de dados, uma vez que os registros deixavam a desejar $(30,87)$

Apesar de já existir uma legislação que regulamentava o registro de nascimentos, casamentos e mortes, no Rio de Janeiro, então capital do Brasil, somente em novembro de 1891 (decreto $n^{\circ} 680$ ) é que ocorreu a padronização de um documento único, contendo dados necessários para a realização de análise demográfico-sanitária. A grande inovação deste formulário era a presença de um campo com a causa mortis, que deveria ser preenchido pelo médico que cuidou do paciente. Como não havia causa de morte nos registros, até esta data, os 
estudos de mortalidade tinham como fonte de eleição as notícias dos jornais que, diariamente, publicavam os óbitos ocorridos na cidade ${ }^{(1)}$.

Este documento era válido apenas no Distrito Federal, mas, mesmo assim, suscitou várias críticas na corporação médica em geral, que questionava principalmente aspectos éticos, uma vez que escrevendo a causa mortis estariam contrariando o princípio do segredo profissional, definido pelo artigo 192 do Código Penal e pelo Código de Ética Médica adotado pelas associações médicas do País.

Apesar das críticas este documento passou a vigorar. Portanto, no final do século $X I X$ e início do $X X$, aparecem alguns trabalhos utilizando a estatística de mortalidade com objetivos específicos, como por exemplo: Oliveira ${ }^{(74)}$ publicou seus estudos de estatística vital na Gazeta Médica da Bahia (1898 e 1899), descrevendo as mortes segundo idade, sexo, nacionalidade, raça, causa da morte, profissão, mês de ocorrência, local da inumação. Paralelamente a este trabalho, ele passou a analisar a qualidade destes dados e colocava que os grandes responsáveis pela má qualidade eram os órgãos governamentais, que não tomavam as medidas necessárias para se ter um sistema de registro civil em "ordem de prestar os seus reais resultados... "

O que se verificava era que, apesar da obrigatoriedade legal dos registros de morte, havia necessidade de se instituir um documento único, padronizado, para que as informações pudessem ser coletadas de forma mais precisa. Acrescese que já surgira a necessidade de se darem novas respostas à sociedade, além do número de pessoas que morrem, as informações deveriam proporcionar conhecimento do quê e do por quê morrem ${ }^{(2,104,105,106)}$.

Puech ${ }^{(83)}$, médico da Santa Casa de Misericórdia de São Paulo, em um trabalho sobre atestado de óbito, publicado em 1919, apontava que havia muita confusão entre os conceitos de causa mortis e a causa direta da morte. Dizia que era fato corriqueiro se colocar no atestado como causa mortis uma broncopneumonia, mesmo que esta tivesse ocorrido como conseqüência de um sarampo. 
Desta forma, discutiam que estes atestados possuíam pequeno valor e às vezes serviam para encobrir crimes, prejudicar o trabalho das autoridades de saúde, incluindo aqui a qualidade das informaçōes estatisticas. $O$ que se propunha era a alteração e unificação dos atestados de óbito, o que ocorreu muito tempo depois.

Em 1925, uma Comissão da Liga das Nações elaborou e propôs, através de um informe, que todos os países utilizassem um modelo único de atestado de óbito ${ }^{(85)}$. Em 1927 a Inglaterra e o Canadá adotaram este modelo.

Quando da Conferência Internacional para a Sexta Revisão da Classificação Internacional de Doenças, em 1948, este impresso foi adotado como "Modelo Internacional de Atestado de Óbito" e implantado em praticamente todo mundo, desde 1950. Junto com este modelo internacional, a comissão fez uma proposta de definição de causa básica de morte, que deveria ser considerada para as estatísticas de mortalidade tendo sido aprovada neste encontro ${ }^{(47)}$.

O Brasil adotou, para todo o País, o Modelo Internacional de Atestado de Óbito também em 1950, a exemplo de outros países, mas havia algumas diferenças em relação aos dados de identificação e à forma do impresso (formato e cores).

Desde esta época, em vários países do mundo e inclusive no Brasil, vem se investindo na capacitação dos profissionais médicos para o correto preenchimento das DO. Já em 1956, foi publicado um livro, por Freitas Filho, que discutia, segundo a avaliação de Laurenti ${ }^{(4 \pi}$, com muita propriedade, o preenchimento do atestado de óbito.

Somente em 1976, o Ministério da Saúde adotou um impresso único, para todo o território nacional, para a Declaração de Óbito, tendo como meta a implantação de um Sistema Nacional de Informação.

\section{I.2. A DECLARAÇÃO DE ÓBITO E A CLASSIFICAÇÃO DE DOENÇAS}

Mesmo antes de se ter um impresso para o registro das causas de morte, já se tinha dificuldade, a partir das Listas de mortalidade que eram elaboradas nas 
paróquias inglesas, de nomear as doenças da mesma forma, pois muitas vezes nomes diferentes se referiam à mesma patologia e, além disso, sentia-se necessidade de agrupá-las segundo uma determinada ordem.

Estes fatos foram demonstrados por Farr, em um estudo sobre a mortalidade dos mineiros, no período de 1848-1853 e 1860-1862, em Cornwall, em que apontou a diferença das taxas de mortalidade por doenças pulmonares entre os mineiros e os que não exerciam esta ocupação. Observou que para fins estatísticos era melhor agrupar todas as patologias que se referiam ao trato respiratório em "doenças pulmonares", uma vez que os diferentes distritos registravam estas mortes utilizando várias denominações, tais como: asma, bronquite, laringite, pneumonia, pleurisia, entre outras ${ }^{(32)}$.

Portanto, não bastava contar as pessoas, era necessário, como Graunt já havia feito, classificar as doenças de forma sistemática.

Wells ${ }^{(114)}$ coloca que muitas propostas de classificação de doenças surgiram ao longo da história, tais como as de: "Plater (1680), Sydenham (16241689), Linnaeus(1707-1778), Sauvages (1768), Vogel (1772), MacBride (1772), Cullen (1785), Crichton (1804), Parr (1810), Young (1813) e Mason Good (1817)."

De todas estas, a única que foi adotada na Inglaterra e Gales, mas diga-se de passagem, com pouca aceitação para as análises estatísticas, foi a de Cullen.

Em 1853, ocorreu o $1^{\circ}$ Congresso Internacional de Estatística, onde se admitiu a necessidade de que todos os países tivessem uma nomenclatura uniforme das causas de morte. Farr, de Londres, e d'Espine, de Gênova, foram encarregados de elaborar, cada um, uma proposta, que foram apreciadas no $2^{\circ}$ Congresso, em 1855, em Paris.

Deste encontro resultou uma lista de 138 causas de morte, agrupadas em 5 classes, conforme a proposta de Farr. Mas seu uso ainda foi muito limitado. $\mathrm{O}$ Congresso Internacional de Estatística revisou esta lista em 1864, 1874, 1880 e $1886^{(114)}$.

O objetivo fundamental da Classificação Internacional de Doenças (CID), desde sua consolidação, na metade do século XIX, era ser um instrumento estatistico para contar e estudar as causas de morte ${ }^{(114,115)}$, uma vez que esta 
análise melhoraria as medidas de intervenção, visando a prevenção das doenças e mortes. Mas havia problemas quando mais de uma causa de morte era apontada pelo médico que atendeu o paciente. Assim, desde a primeira conferência para revisão da CID, estabeleceram-se regras para o tratamento estatístico de causas múltiplas de morte.

O Congresso Internacional de Estatística deu lugar ao Instituto Internacional de Estatística e, em 1891, este Instituto cria um comitê, em decorrência de uma avaliação que os paises não adotavam a mesma lista de causas de morte. Este comitê elaborou uma nova lista, aprovada em 1893, e que apresentava muitas similaridades com a de Farr ${ }^{(114)}$.

Apesar de ter sido reconhecida internacionalmente, o Comitê utilizou uma estratégia de divulgação maciça que passava pelas autoridades responsáveis pelos registros de morte dos diferentes países e também pelas suas respectivas associaçōes médicas. Em 1900, esta nomenclatura passa por sua primeira revisão, quando se adotou o princípio de se selecionar somente uma causa para cada morte ${ }^{(39)}$. Quando da segunda revisão, em 1909, Bertillon, coordenador do Comitê, afirmou que naquele momento a maioria dos países estava utilizando aquela Classificação.

Importante salientar que mesmo tendo uma classificação de doenças, aceita praticamente no mundo todo, essa ainda sofria indiretamente com a imprecisão dos registros de morte. E mesmo a Liga das Nações tendo proposto um modelo único de atestado de óbito em 1925, foi somente em 1950 que a maioria dos países o adotou. Portanto, dois anos após a Conferência Internacional para a Sexta Revisão da CID tê-lo aprovado como o "Modelo Internacional de Atestado de Óbito".

Hoje o uso da CID está consagrado no mundo todo, mas vem se deparando com novos problemas, possivelmente pelo envelhecimento da população (pessoas de mais idade têm um número maior de patologias que coexistem) e pela enorme produção de conhecimentos na área médica. Desta forma, alguém que morreu por "morte súbita", em 1910, poderia ter como diagnóstico, em 1930, uma miocardite 
ou hemorragia cerebral. E, em 1950, poderia ter morrido com diagnóstico de trombose coronariana ${ }^{(114)}$.

\section{I.3. SISTEMA DE INFORMAÇÃO EM SAÚDE E SISTEMA DE INFORMAÇÃO DE MORTALIDADE}

Quando se pensa no desenvolvimento de uma classificação de causas de doenças, tal como a CID, em modelos de atestado de óbito, registros oficiais e sistemáticos de nascimentos, casamentos e óbitos, discute-se, em última análise, a criação de um sistema de informação, que pode ser entendido como um conjunto de unidades de produção, análise e divulgação dos dados, sendo estes caracterizados como um valor quantitativo bruto, não tendo sido submetidos a um tratamento estatístico. A informação consistiria no dado já trabalhado, ou seja, capaz de promover conhecimento, muitas vezes necessitando combinar e analisar vários dados ${ }^{(\varpi, 6)}$.

O objetivo principal de um Sistema de Informação em Saúde (SIS) é obter (e fornecer) dados nas seguintes áreas: demográfica (população, natalidade e mortalidade), de morbidade (hospitalar, ambulatorial, registros especiais), do meio ambiente, dos serviços de saúde (recursos e produção)'e das legislações médicosanitárias.

O que chama atenção, quando se trabalha com sistemas de informações de uma maneira geral e com a saúde em particular, é que na escolha das variáveis e dos indicadores que serão utilizados não há neutralidade. Ou seja, esta escolha mostra qual a diretriz real da política de saúde que está sendo construída, uma vez que existe uma racionalidade entre os dados que serão coletados, processados e analisados e sua real utilização ${ }^{(65)}$.

De há muito se verifica que gerar informações a partir de dados de mortalidade proporciona diagnósticos de saúde de melhor qualidade, em relação às informações geradas de dados de morbidade. Vários fatores são apontados para isto, entre eles: o fato de a morte ser um evento único, a existência de um 
impresso padronizado para o seu registro e a existência de um fluxo de informação definido ${ }^{(48)}$.

Desta maneira, os dados de mortalidade são importantes para a elaboração de indicadores que vão compor os diagnósticos de saúde que farão parte dos planos de saúde, tanto nacionais como estaduais. Mas Barata aponta que estes diagnósticos eram muito pouco utilizados para fins administrativos, uma vez que havia um descompasso entre a racionalidade administrativa utilizada nos século $\mathrm{XIX}$ até na segunda metade do $\mathrm{XX}$, e a "racionalidade" epidemiológica que seria necessária para o uso de tais informações ${ }^{(5)}$.

A necessidade de saúde exposta pelos dados de mortalidade geralmente extrapolava a competência técnica dos serviços básicos de saúde. Nas últimas décadas, culminando com a criação do SUS e de sua regulamentação com a Lei $n^{\circ} 8080$, que diz claramente em seu capítulo II, art $7^{\circ}$, VII: "utilização da epidemiologia para o estabelecimento de prioridades, a alocação de recursos e a orientação programática..." necessita-se que o SIS seja diferente. Este sistema deve possibilitar análise de situações de saúde, com a finalidade da construção de sistemas locais de saúde onde "serviços de diferentes complexidades tecnológicas se articulem e respondam ao conjunto de necessidades de saúde de uma dada população conhecida e delimitada espacialmente, portanto, recoloca a questão das informações de mortalidade" (æ).

Em 1975, foi criado pelo Ministério da Saúde um Sistema de Informação em Mortalidade (SIM), portanto, instituido em época de centralização e verticalização do sistema de saúde e padecendo dos males dessa racionalidade. Mesmo assim, havia um esforço para que estes dados fossem descentralizados. Para que isto ocorresse seria necessária uma grande quantidade de profissionais capacitados em codificar a causa básica de morte, a partir dos atestados de óbito.

O Ministério da Saúde, em 1985, publicou um "Manual de Instruções Para o Preenchimento dos Atestados de Óbito" (55), que foi amplamente divulgado através de palestras, conferências, discussões com médicos, atividades estas promovidas pelo Centro Brasileiro de Classificação de Doenças. Este Manual foi distribuído aos médicos pelas Secretarias Estaduais de Saúde de todo o Brasil ${ }^{(47,64)}$. 
No final da década de 90 , nasce junto ao SIM um sistema informatizado para selecionar a causa básica de óbito, disponivel para todas as Secretarias Municipais de Saúde do país.

Mesmo com estes investimentos, o preenchimento das declarações de óbito (DO) deixa a desejar, tanto do ponto de vista quantitativo como qualitativo. Paula et al compararam o preenchimento da DO em diferentes regiões do Brasil, constatando diferenças entre elas, principalmente no que se refere ao campo do Atestado Médico ${ }^{(78)}$.

\section{I.4. A QUALIDADE DA INFORMAÇÃO E A DECLARAÇÃO DE ÓBITO}

Em toda história da estruturação do instrumento - declaração de óbito - já descrita, verifica-se que junto à exigência de se construir um instrumento que possibilitasse conhecer as causas de morte vinha a necessidade de se obterem informações de boa qualidade. Graunt foi um dos primeiros que chamou atenção para a qualidade dos dados das listas de mortalidade ${ }^{(92)}$.

Para se analisar a situação de saúde de qualquer sociedade lança-se mão de dados populacionais, de natalidade, mortalidade e morbidade, entre outros.

Com a finalidade de monitorar (planejar, implementar e avaliar) as condições de saúde de uma população, os dados de mortalidade são fundamentais, desde que sejam fidedignos ${ }^{(78)}$.

Muitos trabalhos têm demonstrado que nem sempre a declaração de óbito é suficiente para dar a exatidão das causas de morte. As causas apontadas são em geral: falta de treinamento dos médicos em relação ao preenchimento da DO, dificuldade de se obterem dados de autópsia para completar as informações e dificuldade de determinar a causa básica de morte ${ }^{(114)}$

O contínuo interesse pela análise de mortalidade reside no fato que há uma intima correlação entre o padrão de mortalidade de uma população e a estruturação da sociedade, bem como de sua dinâmica social - complexa e mutável $^{(8)}$. 
Assim, estes dados devem ter alguma qualidade, uma vez que são pontos de partida para diagnósticos de saúde das localidades que estão sendo analisadas, e cada vez mais estas informações são levadas em conta para programas de intervenção. Se o grau de inadequação for muito grande, podem-se estar estabelecendo planos de ação um tanto quanto inadequados também.

Há muito se sabe que através das informações de mortalidade podem-se analisar as condições de vida das pessoas. Paim, em seu trabalho "Abordagens teórico - conceituais em estudos de condições de vida: notas para reflexão e ação", menciona que já em 1828 Villermé demonstrou que as taxas de mortalidade na França se vinculavam com as condições de vida dos franceses segundo as classes sociais e bairros ${ }^{(77)}$.

Diversos trabalhos têm demonstrado a taxa de exatidão das informações contidas nos atestado de óbito. No Brasil, vários pesquisadores fazem estudos para caracterizar o vínculo entre os indicadores de mortalidade e as condições de vida ${ }^{(70)}$.

Laurenti ${ }^{(51)}$, em uma revisão bibliográfica sobre trabalhos que discutem a exatidão dos atestados de óbito, levantou 48 pesquisas produzidas entre 1923 e 1996, sendo que $60 \%$ delas foram publicadas após os anos 80 .

Neste trabalho, ele agrupa as pesquisas em 5 subgrupos: 1) achados de autópsia como medida para a exatidão de diagnósticos, 2) informações da DO comparadas com dados clínicos, 3) exatidão dos dados de mortalidade e diferenças entre médicos quando preenchem o atestado de óbito, 4) diferenças na codificação da causa básica de morte e 5) outros tipos de estudo da exatidão dos dados de mortalidade.

No primeiro subgrupo ele menciona estudos cujas DO foram comparadas com relatórios de necropsias. Entre eles, relaciona os trabalhos de Cabot, de 1900, que foi citado nos trabalhos de Moriyama, Loy e Robb - Smith ${ }^{(67)}$, Wells ${ }^{(113)}$, em 1923, Swartout e Webster $(1940)^{(107)}$. Menciona ainda outros nove estudos cujas taxas de concordância entre as DO e os resultados das necropsias variaram de $96 \%$ para tuberculose pulmonar até $45 \%$ em trabalhos que calcularam taxas globais, ou seja, sem especificar uma patologia em si. 
No segundo subgrupo citou 12 trabalhos que, em linhas gerais, "refaziam" a DO, buscando outras fontes de dados, tais como: entrevista com o médico que atendeu o paciente, prontuários dos serviços ambulatoriais e ou hospitalares onde o doente foi atendido, resultados de exames complementares, entrevista com a família e, quando fosse possível, o resultado da autópsia. As diferenças encontradas entre a DO original e a refeita variaram de trabalho para trabalho.

No Brasil, compilou seis trabalhos ${ }^{(15,71)}$, dois deles do próprio Laurenti ${ }^{(46,50)}$, em um desses o autor compara as DO originais com prontuários médicos de hospitais na cidade de SP, encontrando um grau de concordância de $62,3 \%$. Em outro estudo, que verifica as mortes que ocorrem entre mulheres de 10 a 49 anos, observou que a mortalidade materna era 2,24 vezes a relacionada a partir das DO oficiais. Interessante ressaltar que além de alterar a taxa de mortalidade materna, mostrando que o problema estava subestimado, também outras causas foram desvendadas, uma vez que sequer apareciam nas DO das mulheres, como é o caso do alcoolismo ${ }^{\text {(33) }}$.

Fonseca e Laurenti ${ }^{(33)}$ analisaram também o preenchimento de uma amostra de DO de pessoas que morreram em hospitais e Pronto - Socorros, de março de 1971 a fevereiro de 1972, levando em conta a parte I e II, o intervalo de tempo da doença até a morte e a existência de exames complementares. De cada uma das pessoas que morreram nos hospitais, levantou-se o prontuário médico para verificar a verdadeira causa de morte. Verificaram que somente $4 \%$ dos atestados continham a informação do tempo e dos exames complementares. Trinta e um porcento dos atestados não tinham a verdadeira causa básica anotada na DO, e mais, comparando com trabalho semelhante realizado em 1962 e 63, concluiram que não houve melhora na "certificação médica da causa de morte nos últimos 10 anos".

Entre os estrangeiros, um grande estudo foi o realizado por Puffer e Griffith (72), em 1962/64, investigando a mortalidade em 12 cidades do continente americano, e o de Kuller et al ${ }^{(45)}$. 
O terceiro subgrupo citado por Laurenti, refere - se à exatidão dos dados de mortalidade e diferenças entre médicos, quanto ao preenchimento da $\mathrm{DO}$. De início já aponta que há poucos estudos que abordam este tema.

Neste caso, menciona o de Moriyama et al ${ }^{(66)}$, que estudaram uma amostra de pessoas que morreram no estado da Pensilvânia, EUA, em 1956, onde os médicos que haviam assinado os atestados de óbito foram interrogados sobre os métodos de diagnósticos que haviam se baseado para realizar a classificação médica, sua avaliação sobre o grau de veracidade dos diagnósticos descritos e a necessidade de revisão do atestado médico.

Trabalho semelhante foi realizado em 75 hospitais ingleses, onde os clínicos que atenderam os doentes que vieram a morrer preencheram a DO. Estes ainda classificaram se a causa da morte declarada era razoavelmente certa, provável ou incerta. Após a autópsia, o patologista também preencheu uma DO. Ambas as DO foram codificadas utilizando a CID e verificou-se o nivel de concordância entre elas. Das 9501 mortes estudadas, somente 45\% apresentaram concordância ${ }^{(72)}$.

O estudo realizado por Dorn e Horn ${ }^{(27)}$, publicado em 1941, encontrou várias diferenças nas causas de morte e entre as explicações que os autores apontaram para estes resultados citam a solicitação da família de não relatar determinados diagnósticos, dificuldade dos médicos em sintetizarem a história clínica para colocarem na DO e o não entendimento da causa básica, em casos de câncer, uma vez que se preenchia a DO, considerando o câncer metastático como causa básica.

O $4^{\circ}$ subgrupo conta com seis trabalhos, um deles realizado pelo Centro Brasileiro de Classificação de Doenças, que avaliou codificadores de 20 estados brasileiros, com $61 \%$ de codificações consideradas corretas ${ }^{(49)}$.

No $5^{\circ}$ subgrupo há a citação de sete trabalhos com diferentes desenhos metodológicos: um estudo de corte realizado por Barros et al ${ }^{(9)}$, outro de Mayer, que levantou DO em uma corte de soldados da guerra do Vietnan e outros estudos que são interessantes 'a medida em que utilizàm o registro dos doentes em outros bancos de dados e os comparam com a DO . 
Em quase a totalidade da bibliografia consultada, é interessante observar que há uma discussão da $\mathrm{DO}$, tanto quantitativa como qualitativamente. $\mathrm{A}$ análise quantitativa no Brasil reside em duas questões fundamentais: 1- sub registro de morte em várias regiões do País e 2- a relação entre o número de campos existentes na DO para serem preenchidos e o efetivamente preenchido. Tanto o primeiro quanto o segundo ponto deixam a desejar.

$\mathrm{Na}$ análise quantitativa, assim como na qualitativa, sempre há referência aos profissionais médicos que são os responsáveis pelo preenchimento desse instrumento. Geralmente esta análise se restringe a um ou dois parágrafos e, invariavelmente, apontam como causa deste mal preenchimento a falta de informação dos médicos, desde o curso de graduação que não dispõe de uma disciplina formal que aborde o tema e o capacite efetivamente, até treinamentos posteriores que não estão disponíveis em grande escala.

Possivelmente, esta é uma das causas que deve ser levada em conta, mas há outras hipóteses para explicar o comportamento do profissional frente a este documento. Estas hipóteses passam por: medo, à medida que este é um impresso oficial com "profundas implicações jurídicas", como coloca Munoz et a ${ }^{(6)}$, no trabalho "Normas práticas para o fornecimento de atestado de óbito", pois é uma prova legal que aquela pessoa desapareceu. Enfim, algo que ficará registrado para sempre no Livro da Vida daquela pessoa com a "assinatura" do médico, responsável pelas informações ali contidas ${ }^{(29,57)}$.

Outra hipótese é que, mais que não ser capacitado para preencher o atestado de óbito, o médico não é preparado para trabalhar com a morte das pessoas que estão sob seus cuidados.

Verifica-se ao longo da história que o enfrentamento da morte passa por diferentes fases. No século XIX, no Brasil, esta era tratada até com certo júbilo, uma vez que se considerava que a morte do corpo liberaria o espírito para uma outra vida. A morte ideal não poderia ser solitária, precisava estar ligada ao cotidiano, portanto deveria ocorrer em casa, entre os entes queridos, familiares ou não. Ou seja, as pessoas presidiam a sua própria morte ${ }^{(86)}$. 
Pitta ${ }^{(80)}$ discute no livro de sua autoria "Hospital: dor e morte como Ofício" que o fato de se morrer no domicilio, sendo um ato mais público do que privado, as pessoas lidavam com a morte de uma forma mais natural, o processo da morte era considerado como parte da vida e todos tinham oportunidade de vivenciá-la.

Antunes (1), em seu trabalho Medicina, Leis e Moral, discute a morte, trazendo relatos de Ariès e lllich, apontando que a prática médica se hipertrofiou e medicalizou a morte. $O$ médico se colocou entre o doente e a morte e conceituou o ideal de morte natural como sendo aquela que aconteceria "em seres medicamente acompanhados, saudáveis e de idade avançada", de tal forma que se privou o doente da sua própria morte.

Reis, em seu livro "A morte é uma festa", discutiu a medicalização da morte no Brasil, a partir de 1830. Afirmou que o médico brasileiro se considerava capaz de elevar o País ao status da Europa, através das intervenções médicas ${ }^{(86)}$.

Com a medicalização da morte, a medicina se propôs a cuidar dos mortos, segundo as "necessidades e interesses" dos vivos ${ }^{(1)}$.

Pode ser que o fato de a área médica ter "medicalizado" a morte, como descrito anteriormente, já seja uma amostra da dificuldade dos profissionais de a encararem.

Esta informação é verificada hoje, quando Viana e Piccelli (111) entrevistaram estudantes da fase pré-clínica e fase clínica do curso médico (52 médicos e 54 professores da Faculdade de Ciências Médicas da Universidade de Brasília - UNB). Constataram um grande interesse pelo tema (93\%), mas $55 \%$ apontaram dificuldade para tratar com ele. Em suma, sugerem que, mesmo que o problema existencial frente à morte não seja resolvido facilmente, o curso médico poderia promover uma atenção permanente ao tema, para que os profissionais se tornassem mais aptos para enfrentar a morte de seus clientes.

Neste mesmo enfoque, Rosa ${ }^{(90)}$, em um estudo sobre "A morte e o ensino médico", aponta que o medo aparece em qualquer tipo de atividade profissional, mas na medicina o medo reside na consciência da própria morte e isto exige que o profissional seja melhor preparado. Através de questionários que enviou para estudantes de medicina, residentes e médicos, concluiu que a escola não cumpriu 
o seu papel, por não ter oferecido meios para os profissionais lidarem com a morte ( $82 \%$ dos alunos do último ano e $75 \%$ dos professores). A regra acadêmica ao se falar da morte é o SILÊNCIO.

Bromberg ${ }^{(12)}$, colocando sua experiência em trabalhar com profissionais de saúde com dificuldades em enfrentar situações de morte em seu cotidiano, aponta que "morrer é desafiar a postura desafiadora daquele que luta contra a morte, como profissional". E vai mais além: diz que, para aprender a lidar com a morte, há que se aprender lidar com a vida, uma vez que a morte é parte "inextricável" da vida. Observa ainda que na formação dos profissionais de saúde, principalmente médicos, pouco ou nenhum espaço é reservado para que se faça a abordagem e o estudo da morte. Alguns autores até discutem que não só não se fala sobre a morte, mas que este tema é evitado.

Desta maneira, como desejar que os médicos preencham bem os atestados, uma vez que estes significam a concretude da falência do cuidado, a tomada de consciência de sua finitude?... Nada do que ele (profissional) está preparado para enfrentar.

Por fim, outro fator que, possivelmente, também interfere na qualidade do preenchimento da DO é o relacionado à organização da assistência médica no Brasil e à forma como a medicina se estrutura, enquanto prática a partir das escolas médicas. Segundo Campos ${ }^{(13)}$, o objeto de estudo e de intervenção da medicina está reduzido, seja por estar com um olhar voltado para os fenômenos biológicos, em detrimento das dimensões subjetiva e social dos indivíduos, seja por centrarem-se na doença e não nas pessoas. Em algumas ocasiōes, avança-se um pouco e se consegue considerar o individuo, mas geralmente ele é ainda fragmentado, composto de partes, que mantêm alguma interdependência. $E$ o que se verifica, analisa ainda Campos, é que os profissionais estão há algum tempo em um processo contínuo de alienação em "relação aos sujeitos concretos dependentes de seus cuidados". Esta alienação se reflete em afastamento, desinteresse, padronização de procedimentos, dificuldade em ouvir queixas e de se comunicar fora dos padrōes já automatizados. 
Bem, uma vez com esta realidade não é muito difícil imaginar que se o médico não consegue "olhar" para o sujeito que está doente, sujeito este, vivo, que deambula, pranteia, pulsa, o que dirá de um sujeito que "desapareceu", que apresenta "cessação completa de sinais vitais" ?

Levando em conta estas questões, relacionadas às possiveis dificuldades que o médico tem para preencher o atestado de óbito, não será exigir muito que, a partir de uma palestra ou uma aula no curso de graduação, ele passe a considerar o DO como fundamental ?

Melhorar a qualidade das informações em geral e de mortalidade em particular é mais do que uma questão técnica, é uma possibilidade de disponibilizar informações, para que a própria sociedade possa decidir o seu destino, atuando sobre seus problemas.

Pode ser que o aprofundamento das razões do mau preenchimento das DO, pelos médicos, possibilite reflexões que até este momento estão encobertas, ou seja, os dados ignorados na DO além de serem um indicador de qualidade que contribui para o desconhecimento da realidade de saúde, como aponta Barros (7), também podem ser um dos indicadores da qualidade da formação médica no pais. 


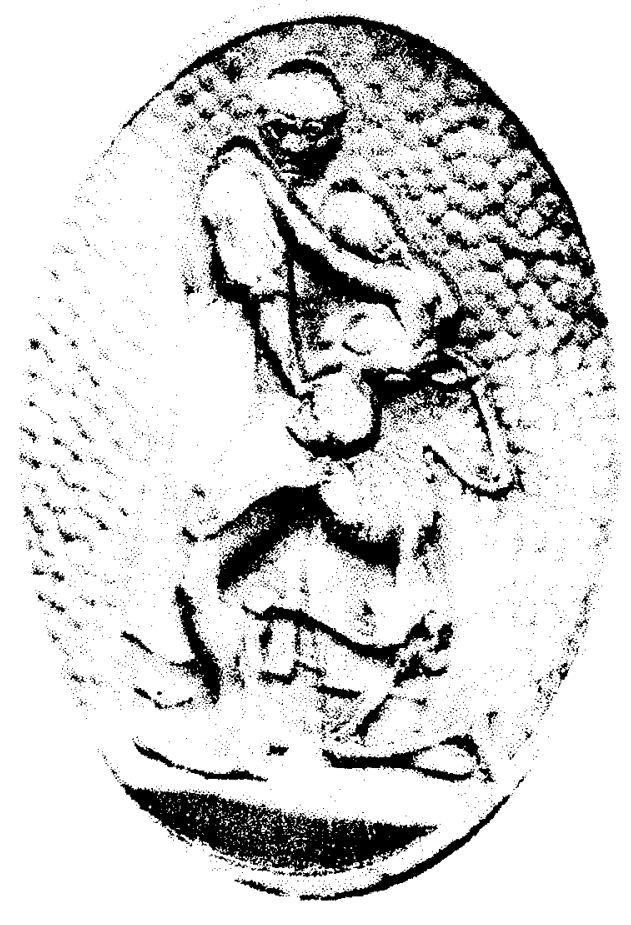




\section{II.OBJETIVOS:}




\section{II.1. OBJETIVO GERAL}

Avaliar o preenchimento dos campos de informações que compõem a Declaração de Óbito, bem como, descrever os fatores que podem interferir neste preenchimento, relativos aos médicos.

\section{II.2. OBJETIVOS ESPECÍFICOS}

1- Verificar a qualidade do preenchimento dos diferentes itens que compõem a DO.

2- Descrever o momento em que se dá conhecimento ao médico em relação ao preenchimento da DO e suas finalidades.

3- Descrever como se dá o preenchimento da DO considerando o cotidiano do trabalho médico.

4- Levantar a relação entre o preenchimento da $\mathrm{DO}$ e a forma como os médicos encaram a morte e os sentimentos associados.

5- Descrever as características dos médicos que preenchem as DO, tais como: idade, sexo, tempo de formado e especialidade. 


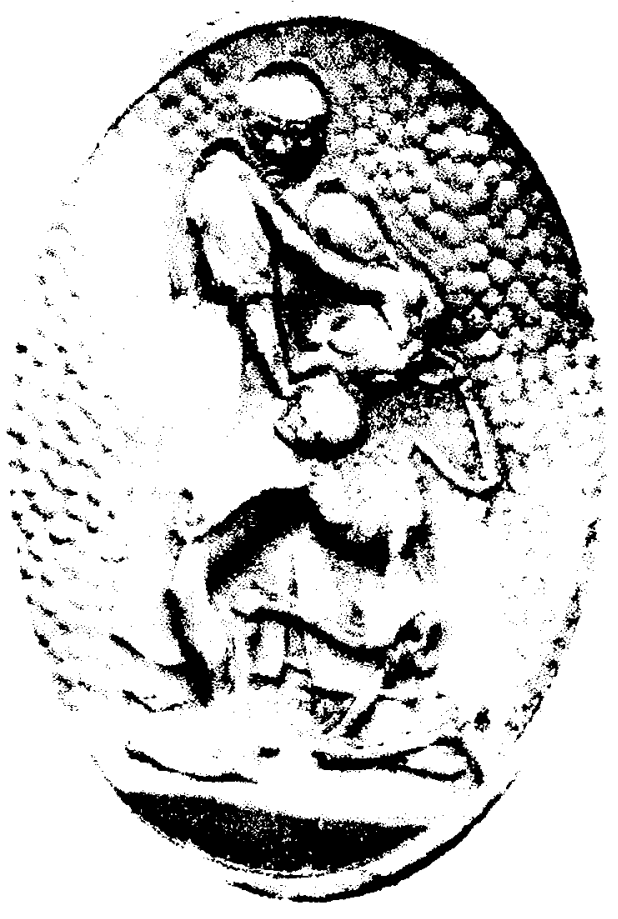




\section{III - METODOLOGIA:}


Este trabalho compreendeu duas fases: em primeiro lugar, uma análise da qualidade do preenchimento das declarações e, posteriormente, uma pesquisa qualitativa com os médicos que preencheram as DO analisadas.

Foi utilizada parte do material que serviu de base para o projeto "O Sistema de Informação sobre Mortalidade: problemas e propostas para seu enfrentamento" realizado por Mello Jorge e Gotlieb ${ }^{(56)}$. Esta pesquisa propôs-se a avaliar o Sistema de Informação de Mortalidade do Ministério da Saúde tanto do ponto de vista quantitativo quanto qualitativo e, também, testar técnicas fáceis e uniformes capazes de minimizar as possiveis distorções.

As áreas geográficas escolhidas para o desenvolvimento do projeto foram Sergipe, Mato Grosso e São Paulo. No Estado de São Paulo foram escolhidos, por conveniência, os municípios de Marilia, Tupã, Garça, Oswaldo Cruz e Echaporã, todos pertencentes à Diretoria Regional de Saúde de Marilia (DIR14). Os critérios para a escolha destes locais foram: número de habitantes, garantindo que houvesse municipios de pequeno e médio porte, facilidade de acesso, uma vez que se contava com a participação de pessoas que trabalhavam nas secretarias de saúde, além de serem alunos de pós-graduação da Faculdade de Saúde Pública, e tinham grande interesse na avaliação dos dados de mortalidade.

Como se admitia que no Estado de São Paulo não houvesse problemas de sub-registro de óbitos, procedeu-se somente a análise qualitativa, o que significou verificar a fidedignidade das informaçōes das causas de morte de todas as declarações de óbito (DO) de pessoas falecidas nos municípios em questão, no período de 15 de agosto a 15 de dezembro de 1999. À medida que este projeto apresentava características de um estudo exploratório, considerou-se que um terço do ano forneceria um número satisfatório de DO, para a análise.

Para a realização do presente trabalho foram selecionadas, somente, as DO daqueles que morreram no município de Marília independentemente do fato de serem ou não residentes. 


\section{III.1. Característica da área do estudo}

Marília é um município de médio porte, localizado na região centro - oeste do Estado de São Paulo, apresenta 197.153 habitantes (IBGE-1996), sendo 96.435 homens e 100.718 mulheres. Ocupa uma área de $1.154 \mathrm{~km}^{2}$ com uma densidade demográfica de 170,52 hab/km². (Fundação SEADE - 2000)

Conta com quatro hospitais gerais, sendo dois universitários, além de uma maternidade e um hospital psiquiátrico. Apresenta 17 Unidades Básicas de Saúde e dez Unidades de Saúde da Família, distribuídas por todo o município, incluindo a área rural.

A Secretaria Estadual de Saúde, ainda, mantém um serviço ambulatorial estruturado em especialidades.

Ocorreram, em 1999, no município, 1207 mortes sendo que 534 (45,7\%) aconteceram entre 15 de agosto e 15 de dezembro.

\section{III.2. PRIMEIRA FASE: AVALIAÇÃO QUANTITATIVA}

III.2.1: Seleção das Declarações de Óbito para análise

A Secretaria Municipal de Saúde responsabilizou - se por fornecer cópias de todas as DO das pessoas que morreram no município de Marília no período definido.

Estas DO foram agrupadas em: GRUPO I - aquelas com causa básica definida, GRUPO II - as com causa básica mal definida (CID 10 - capítulo XVIII) ou residuais de cada capítulo (diagnósticos incompletos), incluindo as mortes que ocorreram no domicílio, GRUPO III - relativas às causas externas (CID 10capitulo XIX e XX), GRUPO IV - de mulheres entre 10 e 49 anos e GRUPO Vaquelas preenchidas com causas básicas presumiveis de AIDS ${ }^{(3,56)}$. 
Este agrupamento foi assim definido seguindo orientação da Organização Panamericana de Saúde, bem como a experiência das autoras do projeto de que estes grupos poderiam demonstrar a má qualidade da informação.

Para a investigação das mortes de todos os grupos, exceto para aquele que apresentava causa básica bem definida, foram aplicadas as fichas de coleta utilizadas na pesquisa nacional (Anexo III: F2, F3, F4 e F5)

$O$ conceito de causa básica de morte utilizado foi 0 definido pela Organização Mundial de Saúde ${ }^{(115)}$.

III-2.1.a : Avaliação das DO com causas básicas bem definidas.

Os atestados de óbito do "GRUPO I" - causa básica bem definida- foram avaliados tomando por base a classificação de Laurenti e Fonseca ${ }^{(33)}$, mas utilizando, desta proposta, somente, dois dos grupos, a saber:

1) completos: quando nos atestados de óbito estavam preenchidos, além da parte I- causa da morte, também, o intervalo de tempo entre o início do processo mórbido e a morte, bem como o item referente ao exame complementar que confirmou o diagnóstico (29). Quando a DO exibia em cada uma das linhas do item 49 causas de morte - patologias que guardavam entre si um encadeamento lógico, ou seja, uma doença era conseqüência da outra, significava que era um atestado que apresentava seqüência com nexo causal. À medida que estas DO mostrassem, ou não, seqüência com nexo causal, foram classificadas como completas com seqüência e completas sem seqüência, respectivamente.

2) incompletas quando não estavam assinalados os itens: intervalo de tempo e ou realização de exames que confirmaram o diagnóstico. Neste grupo, os atestados também foram divididos em com seqüência e sem seqüência, da mesma forma que o anterior. 
Além desta análise, verificou-se o preenchimento, ou não, dos demais itens descritos na DO.

III-2.1.b : Avaliação das DOs com causa básica mal definida, com diagnósticos incompletos, mortes domiciliares, mortes de mulheres de 10 a 49 anos, causa básica presumivel de Aids e por causas externas.

Do grupo de DO que apresentavam causa básica mal definida ou com diagnósticos incompletos (residuais de capítulos), foi verificado o prontuário clínico, tanto o hospitalar quanto o ambulatorial, sendo preenchida a ficha de coleta de dados contendo: datas de internação, do óbito, e um resumo da história clínica da doença que levou o indivíduo à morte, bem como os exames complementares que foram realizados.

Caso o prontuário não fornecesse as informaçōes necessárias da história da causa de morte, lançava-se mão de outras fontes, tais como: entrevista no domicílio da família do doente em questão, laudos do laboratório de patologia, de serviços de oncologia e radioterapia e entrevista com o médico que assinou o atestado.

As informações das pessoas que morreram no domicílio e as mortes de mulheres de 10 a 49 anos foram coletadas, primeiramente, na residência. Os instrumentos de coleta apresentavam um campo onde se anotava se o doente havia sido acompanhado em algum serviço de saúde, hospitalar ou ambulatorial, incluindo consultórios médicos; caso este fato fosse relatado, os registros desses serviços eram pesquisados.

Quando se tratava de consultório particular, entrava-se em contato com o próprio profissional e, para esta entrevista, também foi utilizado um instrumento de coleta especifico.

Para inferir se as causas de morte descritas no atestado eram, ou não, presumíveis de AIDS, utilizou-se uma lista elaborada pelo Center of Diseases 
Control (CDC - Atlanta). Caso uma dessas causas constasse da declaração, este óbito era investigado.

Em relação às causas externas, realizou-se avaliação nos registros do Instituto Médico Legal e, quando necessário, levantamento dos boletins de ocorrência elaborados pelas delegacias de polícia.

A partir de todos os dados coletados, um grupo de pesquisadores experientes no preenchimento de DO elaborou uma nova DO. Os dados foram digitados e processados em Epi-info versão 6 e posteriormente analisados ${ }^{(19)}$.

Estes atestados de óbito foram, posteriormente, analisados segundo 0 proposto por Laurenti e Fonseca, mas utilizando a classificação completa, ou seja, além dos grupos de atestados completos e incompletos, já descritos, também os corretos e incorretos ${ }^{(33)}$.

Como correto considerou-se aquele atestado cuja causa básica nova, após colhidas as informações adicionais, permaneceu a mesma que estava informada $e$ incorreto quando a verdadeira causa básica não estava informada.

\section{III.3. SEGUNDA FASE : AVALIAÇĀO QUALITATIVA}

\section{III-3.1 : Seleção dos médicos para entrevista}

Para cada um dos grupos de DO, ou seja: com causas bem definidas, mal definidas, de mulheres de 10 a 49 anos, com causas presumiveis de AIDS e causas externas, uma lista foi elaborada com os nomes de todos os médicos que assinaram os atestados de óbito do período considerado. Foi feita uma ordenação decrescente, de acordo com o número de DO assinadas. Foram, então, selecionados os primeiros cinco médicos de cada uma das listas dos diferentes grupos que correspondiam aos que mais assinaram atestados, sendo, portanto, entrevistados, ao todo, 25 profissionais.

Quando o mesmo médico constava na lista de dois ou mais subgrupos, ele foi selecionado naquele em que era responsável pelo preenchimento de maior 
número de declarações. Ocorreu, ainda, empate entre alguns médicos (apresentaram o mesmo número de DO assinadas em um mesmo grupo); neste caso, o critério de seleção foi a ordem alfabética de aparecimento na lista elaborada.

Importante pontuar que como os dados foram levantados a partir de declarações de óbito de pessoas que morreram em 1999, os médicos residentes que assinaram as mesmas, naquela época, já nāo estavam mais no serviço; assim, a entrevista foi realizada com os atuais residentes guardando a relação quantitativa, ou seja: selecionaram - se três residentes de $1^{\circ}$ ano e um de $2^{\circ}$ ano, uma vez que era essa proporção de residentes da clínica - médica que mais haviam assinado DO naquele ano.

\section{III.3.2 : Entrevistas}

Para as entrevistas, elaborou-se um questionário semi-estruturado (Anexo II). A clareza e a pertinência do instrumento foram avaliadas a partir da realização de um estudo piloto, com dois profissionais.

Este questionário consta de dois momentos, o primeiro se presta para identificação do profissional: idade, sexo, tempo de formado e especialidade, e o segundo para descrever: (a) o preparo do profissional para o preenchimento da DO; (b) o conhecimento das finalidades do atestado; (c) o sentimento em relação às implicações legais; (d) as dificuldades e ou facilidades que os médicos encontram para completar a DO, levando em conta seu processo de trabalho; e (e) os aspectos relacionados aos sentimentos envolvidos, no momento do preenchimento.

Os 25 médicos selecionados foram entrevistados, após contato prévio e com o termo de consentimento esclarecido devidamente discutido e assinado (Anexo IV).

Interessante mencionar que não houve nenhuma recusa por parte dos profissionais e todos se mostraram disponiveis para conversar sobre o tema. 
Os depoimentos foram gravados com a anuência prévia do entrevistado, garantindo-se o sigilo de todas as questōes que foram discutidas.

As entrevistas de todos os participantes foram transcritas, digitadas e separadas de acordo com cada uma das perguntas do roteiro de entrevista.

Construiu-se, então, uma tabela denominada: Instrumento de Análise de Discurso 1 (IAD1) para cada uma das perguntas que compunha o questionário, com a totalidade das respostas de todos os entrevistados. Em seguida destacaram-se, em cada uma das respostas transcritas nos IAD1, as expressões - chave das idéias - centrais (ANEXO V).

As expressões-chave foram, desta forma, trechos das falas dos entrevistados que podiam estar em sequência ou não. $O$ importante era identificar, neste segmento selecionado, a essência dos discursos. Neste momento descartou-se tudo o que era irrelevante ou secundário.

Em seguida, foram extraídas, das expressões - chave destacadas, a ou as idéia(s) - central(is) (IC) ou seja, foram identificadas "expressão(ões) lingüística(s)" que mostrasse $(m)$ de forma precisa o sentido das expressões chave. Cada uma das IC foi destacada e agrupada segundo a semelhança de sentido ou cujos sentidos se complementassem. Portanto, para cada pergunta foram elaboradas as sinteses das $I C$ encontradas.

Essas sinteses foram organizadas construindo-se um segundo Instrumento de Análise de Discurso (IAD-2). Este IAD2 era composto das expressões-chave relacionadas àquelas IC. Finalmente, as expressōes - chave foram ligadas umas às outras em uma seqüência lógica (começo, meio e fim) elaborando-se os Discursos do Sujeito Coletivo ${ }^{(52)}$ (ANEXO V).

Posteriormente, procedeu-se à análise descritiva dos DSC elaborados, seguida de uma análise interpretativa, retomando as hipóteses levantadas anteriormente. 


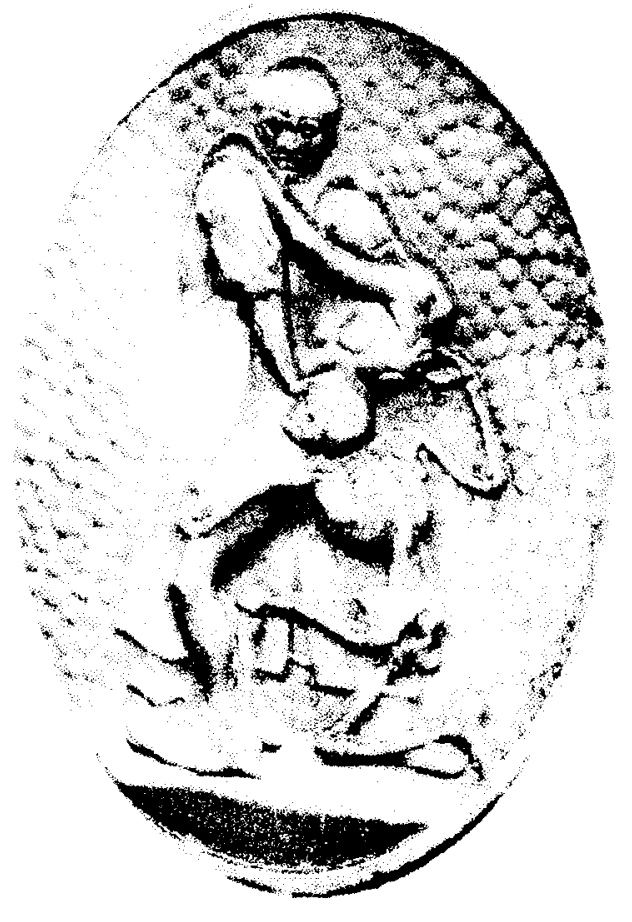




\section{IV - RESULTADOS E DISCUSSÃO:}




\section{1. PRIMEIRA FASE: AVALIAÇÃO QUANTITATIVA}

Todas as declarações de óbito das 534 pessoas que morreram no municipio de Marilia, no periodo de 15 de agosto a 15 de dezembro de 1999 , foram pesquisadas e analisadas. Em um primeiro momento, foram classificadas em cinco GRUPOS, a saber: I - declarações que continham causas básicas de morte bem definidas, totalizando 355 atestados, exceto os casos de mortes de mulheres de 10 a 49 anos, óbitos por causas externas e de causas presumiveis de AIDS; II - Cento e quatro declarações cujas causas de óbito eram mal definidas ou residuais de capitulo; III - Vinte mortes de mulheres na faixa etária de 10 a 49 anos; IV - Quarenta e oito mortes por causas externas e V - Dezessete declarações de óbito cujas causas eram presumiveis de AIDS (Gráfico 1)

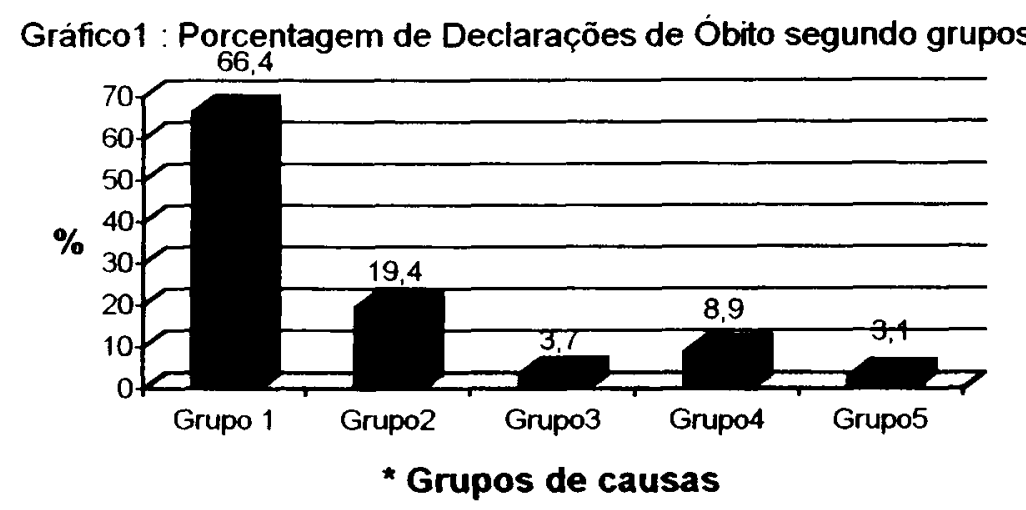

Grupo1 - DO com causas básicas bem definidas

Grupo2 - DO com causas básicas mal definidas e residuais de capitulo

Grupo3 - DO de mulheres em idade fértil

Grupo 4 - DO com causas externas

Grupo5 - DO com causas presumiveis de AIDS

Os atestados de óbito com causa básica bem definida (GRUPO I), que não entraram nos demais grupos (óbitos de mulheres de 10 a 49 anos, presumiveis de AIDS e causas externas), foram analisados levando-se em conta o preenchimento dos demais campos da DO. Para efeito da classificação da DO em completa e 
incompleta, levou-se em consideração a existência de causa básica definida, o preenchimento do intervalo de tempo transcorrido entre o início do processo mórbido e a morte, e o item referente ao exame complementar que confirmou o diagnóstico ${ }^{(33)}$.

Dos 355 atestados avaliados no grupo 1, em 334 os campos de "tempo" e/ou "de exames complementares" não estavam preenchidos, isto significa que $94,1 \%$ das DO estavam incompletas (Gráfico 2).

O tempo entre o início da doença e a morte foi o item mais negligenciado $(91,5 \%)$, já o campo de exame complementar não estava completo em $6,5 \%$ das DO. Este dado está de acordo, parcialmente, com o encontrado por Fonseca e Laurenti ${ }^{(33)}$, uma vez que em trabalho realizado em São Paulo a proporção obtida de DO incompletas por conta do item de tempo decorrido entre o início do processo mórbido e a morte foi de $93,5 \%$ e a de exames complementares foi de $65 \%$.

Quanto a este último item verificou-se, no presente estudo, valor diferente, podendo-se inferir que os profissionais do município estão mais atentos para este item ou que ele é de preenchimento mais fácil, uma vez que são caselas fechadas onde se assinala a informação desejada; já, quanto ao item "tempo...", a informação deve ser "criada". Além disso, a Declaração de Óbito foi alterada, no periodo entre a realização do estudo de Fonseca e o atual, o que pode ser um indício de que o novo instrumento tenha facilitado o seu preenchimento.

A importância de se assinalar o item: "tempo aproximado entre o início de doença e a morte "está relacionado a uma das finalidades da DO quanto a ser utilizada para estudos clínicos, principalmente, de seguimento de casos. Como este campo é muito pouco preenchido, pode-se concluir que os médicos, possivelmente, ignoram esta finalidade. 


\section{Gráfico2: Número de Declaraçöes de Óbito com causas básicas bem definidas segundo o grau de preenchimento da parte IV e a existência de sequência lógica entre as causas.}

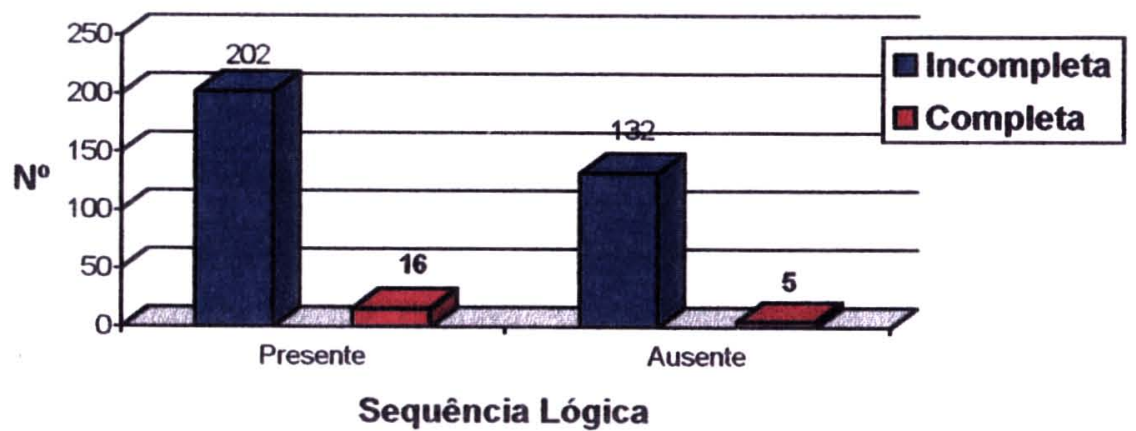

A maioria dos atestados incompletos apresentava seqüência lógica de causas (60,5\% - 202), mas chama a atenção que 35,5\% (132) desses incompletos tinham a seqüência comprometida.

Já entre os atestados completos (21- 6\%), 76,2\% apresentavam nexo causal lógico. Mas em decorrência do pequeno número de DO completas a análise deste dado pode ficar comprometida.

Poderia causar estranheza o fato que das 355 DO com causas bem definidas, $60,5 \%$ fossem incompletas, mas somente reflete a ausência do preenchimento do "tempo". Ao se analisarem todos os Atestados, independente do fato de serem completos ou incompletos, verifica-se que a maioria $(61,4 \%)$ apresentava seqüência lógica entre as causas (Tabela 4).

A parte II - Identificação das DO deste GRUPO I estava em sua grande maioria preenchida, com exceção do item escolaridade, onde em 84\% (301 DO) das vezes se encontrava em branco (Tabela 1). Este fato também foi encontrado em estudo realizado em Brasília na década de $80^{(17)}$. Corroborando estes dados, Heckmann et $\mathrm{al}^{(40)}$ ao analisarem Atestados de Óbito de um município do Rio Grande do Sul apontaram uma alta freqüência de preenchimento dos dados de identificação, se comparados com os demais, colocando que este fato se deve, principalmente, a dois fatores: a) a facilidade com que o médico obtém estes dados junto aos familiares e b) caso a morte ocorra em instituições de saúde, 
estes campos são assinalados pelo pessoal administrativo. Mesmo assim aponta que o item escolaridade estava em branco em $46,6 \%$ das DO.

Em Marilia, os atestados de óbito ficam disponiveis nos hospitais, sob controle da Secretaria Municipal de Saúde, portanto, invariavelmente, os itens referentes à identificação, residência e ocorrência, são preenchidos pelo serviço social e/ou de internação. Estes setores fazem este trabalho utilizando algum documento do falecido que pode ser, carteira de identidade, carteira de trabalho, registro de nascimento, entre outros. De certa forma isto explica, porque o preenchimento do item escolaridade é tão baixo, pois em nenhum dos documentos citados há esta informação.

Tabela 1 - Número e porcentagem de Declarações de Óbito do Grupo I segundo informações que constam na parte II: Identificação.

\begin{tabular}{|c|c|c|c|c|c|c|c|c|}
\hline \multirow{2}{*}{$\begin{array}{l}\text { Informação } \\
\text { Itens da DO }\end{array}$} & \multicolumn{2}{|c|}{ Preenchidas } & \multicolumn{2}{|c|}{ Em branco } & \multicolumn{2}{|c|}{ Ignorada } & \multicolumn{2}{|c|}{ TOTAL } \\
\hline & $\mathrm{N}^{0}$ & $\%$ & $N^{0}$ & $\%$ & $N^{\circ}$ & $\%$ & $N^{0}$ & $\%$ \\
\hline Tipo de óbito & 339 & 94,5 & 16 & 5,5 & $1-$ & & 355 & 100 \\
\hline Data & 355 & 100 & - & - & - & - & 355 & 100 \\
\hline Idade & 338 & 95,2 & 17 & 4,8 & - & - & 355 & 100 \\
\hline Sexo & 352 & 99,1 & 2 & 0,6 & 1 & 0,3 & 355 & 100 \\
\hline Ocupação & 289 & 90,4 & $66^{1}$ & 9,6 & - & - & 355 & 100 \\
\hline Estado civil & $330^{2}$ & 92,9 & $24^{22}$ & 6,8 & 1 & 0,3 & 355 & 100 \\
\hline Escolaridade & $43^{3}$ & 12,1 & $306^{33}$ & 86,2 & 6 & 1,7 & 355 & 100 \\
\hline
\end{tabular}

- Computados 46 óbitos fetais e de menores de 7 anos

${ }^{2}$ Computados 32 óbitos fetais e de menores de 10 anos

z Computados 14 óbitos fetais e de menores de 10 anos

${ }^{3}$ Computados 15 óbitos fetais e de menores de 7 anos

${ }^{3}$ Computados 31 óbitos fetais e de menores de 7 anos

Em relação ao "tipo de óbito", se fetal ou não, foram encontrados dois atestados que estavam assinalados como fetais mas que eram de pessoas com mais de 70 anos; evidentemente ocorreu um erro de preenchimento, mas à medida que estes dados são digitados e se não houver análise de consistência, os valores podem estar superestimados ou subestimados.

As informações de "estado civil" e "escolaridade" estavam, não raramente, preenchidas para os óbitos fetais e de menores de um ano. No caso da 
"ocupação" em algumas delas estava escrito "menor", como se fosse necessário justificar o não preenchimento desse campo.

Já em relação ao estado civil, nos óbitos fetais e nos de menores de um ano, esse item estava assinalado em $40 \%$ e $87,5 \%$ das DO como Solteiro, respectivamente. Interessante ressaltar que apesar da escolaridade ser muito pouco colocada nos atestados de óbito em geral, nos óbitos de menores de um ano ela aparece em $37,5 \%$ das DO como o recém-nascido não tendo nenhuma escolaridade. De alguma forma este fato demonstra uma desinformação em relação ao preenchimento deste campo e também aponta uma falha no instrumento, uma vez que não consta, no mesmo, um campo específico - não procede - que possa ser assinalado nestes casos.

O preenchimento desse item pode levar a traçar perfis epidemiológicos inadequados, havendo uma superestimativa de pessoas que vêm a morrer, solteiras, analfabetas e sem ocupação.

Tabela 2 - Números e porcentagens de Declarações de Óbito do Grupo I segundo informações que constam nas partes III: Residência e IV: Ocorrência.

\begin{tabular}{|c|c|c|c|c|c|c|c|c|}
\hline \multirow{2}{*}{$\begin{array}{l}\text { Informação } \\
\text { Itens da DO }\end{array}$} & \multicolumn{2}{|c|}{ Preenchidas } & \multicolumn{2}{|c|}{ Em branco } & \multicolumn{2}{|c|}{ Ignorada } & \multicolumn{2}{|c|}{ TOTAL } \\
\hline & $\mathrm{N}^{\circ}$ & $\%$ & $\mathrm{~N}^{0}$ & $\%$ & $\mathrm{~N}^{0}$ & $\%$ & $\mathrm{~N}^{0}$ & $\%$ \\
\hline Residência & 353 & 99,4 & 2 & 0,6 & 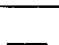 & & 355 & 100 \\
\hline Local & 345 & 97,2 & 10 & 2,8 & - & - & 355 & 100 \\
\hline Estabelecimento & 338 & 95,2 & 17 & 4,8 & - & - & 355 & 100 \\
\hline Endereço de & 240 & 67,5 & 115 & 32,3 & 1 & 0,2 & 355 & 100 \\
\hline Ocorrência & & & & & & & & \\
\hline
\end{tabular}

Ao se analisarem as partes III - Residência e a IV - Ocorrência, verificou-se quanto à primeira parte que $99,4 \%$ das DOs apresentaram o endereço de residência da pessoa; quanto à segunda, na maioria das vezes constava esta informação, mas quando a morte aconteceu em um dado hospital o endereço deste estabelecimento foi omitido em 32,4\% (115) das DO. Não há motivo claro que justifique a ocorrência deste fato (Tabela 2). 
Interessante colocar que neste GRUPO I ocorreu, segundo local de ocorrência da morte, somente, $5 \%(18)$ de mortes domiciliares.

Apesar dos óbitos fetais e infantis não terem se constituído em um grupo especifico, foram avaliados, uma vez que uma das partes do atestado refere-se a dados da mãe que sofreu esta perda (Tabela3).

Dentre as DO com causa básica de morte bem definida ocorreram 15 mortes fetais e 24 de menores de um ano. O preenchimento desses campos é relativamente bom, mesmo assim há itens ainda muito negligenciados, tais como: a escolaridade da mãe (53\%), sua ocupação e o número de filhos.

Tabela 3- Número e porcentagem de Declarações de Óbito do Grupo I segundo informações que constam na parte $V:$ Fetal ou menor de um ano.

\begin{tabular}{|c|c|c|c|c|c|c|c|c|}
\hline \multirow{2}{*}{$\begin{array}{l}\text { Informação Itens da } \\
\text { DO Sobre a mãe }\end{array}$} & \multicolumn{2}{|c|}{ Preenchidas } & \multicolumn{2}{|c|}{ Em branco } & \multicolumn{2}{|c|}{ Ignorada } & \multicolumn{2}{|c|}{ TOTAL } \\
\hline & $\mathbf{N}^{\mathbf{0}}$ & $\%$ & $\mathbf{N}^{\mathbf{O}}$ & $\%$ & $\mathbf{N}^{\circ}$ & $\%$ & No & $\%$ \\
\hline Idade & 36 & 92,3 & 3 & 7,7 & - & - & 39 & 100 \\
\hline Escolaridade & 17 & 43,5 & 21 & 53,8 & 1 & 2,7 & 39 & 100 \\
\hline Ocupação & 27 & 69,2 & 12 & 30,8 & - & - & 39 & 100 \\
\hline$N^{0}$ de filhos & 30 & 76,9 & 9 & 23,1 & - & - & 39 & 100 \\
\hline Duração da gestação & 38 & 97,4 & $1-$ & - & 1 & 2,6 & 39 & 100 \\
\hline Tipo de gravidez & 39 & 100 & - & - & - & - & 39 & 100 \\
\hline Tipo de parto & 39 & 100 & - & - & - & - & 39 & 100 \\
\hline $\begin{array}{l}\text { Morte em relação ao } \\
\text { parto }\end{array}$ & 37 & 94,8 & 2 & 5,2 & - & - & 39 & 100 \\
\hline Peso ao nascer & 38 & 97,4 & 1 & 2,6 & - & - & 39 & 100 \\
\hline $\mathbf{N}^{\circ}$ da DN * & 18 & 75,0 & 6 & 25,0 & - & - & 24 & 100 \\
\hline
\end{tabular}

^Este dado se refere somente às mortes de menores de um ano

Em estudo realizado em Brasília (1977/78) por Pereira e Castro(79), encontrou-se que em $50 \%$ dos óbitos fetais e $67 \%$ dos menores de 1 ano não existiam os dados referentes à gravidez e ao parto, o que não ocorreu neste trabalho, onde estas variáveis foram assinaladas em $100 \%$ dos casos.

A parte VI da DO onde constam os dados das "condições e causas do óbito" é de responsabilidade exclusiva do médico. Parte destes campos foi analisada quando as DO foram classificadas em completas e incompletas, mas, para outros itens, também houve interesse em avaliá-los, tais como: item 45- 
"recebeu assistência médica durante a doença que ocasionou a morte?"; item 47 e 48 se o "diagnóstico foi confirmado por cirurgia e/ou necropsia" respectivamente.

Chama atenção que $45 \%$ dos atestados não continham a informação se o doente havia recebido, ou não, assistência médica durante o curso da doença que foi responsável pela morte (Tabela 4). Levando em conta que se está em um município cujo acesso a serviços de saúde é relativamente grande, esta cifra é muito alta.

Tabela 4 - Número e porcentagem de Declarações de Óbito do Grupo I segundo informações que constam na parte Vl: condições e causas do óbito e item 52 da parte VII : médico.

\begin{tabular}{|c|c|c|c|c|c|c|c|c|}
\hline \multirow{2}{*}{$\begin{array}{l}\text { Informação Itens da } \\
\text { DO }\end{array}$} & \multicolumn{2}{|c|}{ Preenchidas } & \multicolumn{2}{|c|}{ Em branco } & \multicolumn{2}{|c|}{ Ignorada } & \multicolumn{2}{|c|}{ TOTAL } \\
\hline & $\mathbf{N}^{0}$ & $\%$ & $\mathbf{N}^{0}$ & $\%$ & $\mathbf{N}^{0}$ & $\%$ & $\mathbf{N}^{\circ}$ & $\%$ \\
\hline Assistência médica & & & & & & & & \\
\hline Exame & 194 & 54,6 & 160 & 45,1 & 1 & 0,3 & 355 & 100 \\
\hline complementar & 326 & 91,8 & 23 & 6,5 & 6 & 1,7 & 355 & 100 \\
\hline Cirurgia & 307 & 86,4 & 44 & 12,4 & 4 & 1,2 & 355 & 100 \\
\hline Necropsia & 290 & 81,7 & 63 & 17,7 & 2 & 0,6 & 355 & 100 \\
\hline $\begin{array}{l}\text { Causas da morte } \\
\text { Parte I }\end{array}$ & 355 & 100 & - & & - & - & 355 & 100 \\
\hline Sequiência lógica * & 218 & 61,4 & 137 & 38,6 & - & - & 355 & 100 \\
\hline Tempo & 26 & 7,2 & 329 & 92,8 & - & - & 355 & 100 \\
\hline Médico' & 336 & 94,6 & 19 & 5,4 & - & - & 355 & 100 \\
\hline
\end{tabular}

"Esta variável não é um item da DO mas foi construída a partir da causa básica e das conseqüenciais colocadas na parte I do item - causas da morte.

'Item 52 - O médico que assina atendeu ao falecido?

Heckmann e colaboradores encontraram no município de Viamão (RS) $35 \%$ de atestados onde este dado não estava preenchido para mortes em pessoas maiores de 1 ano e $53,7 \%$ para óbitos fetais ${ }^{(40)}$. Este fato de alguma forma aponta para alguns fatores: descaso com que este instrumento é preenchido, o não entendimento da importância desta informação ou mesmo sua finalidade e, ainda, o fato de que vários atestados são preenchidos e assinados por médicos que somente atestam as mortes e não as causas destas. Caso seja real este último fator o profissional poderia assinalar a casela - ignorado. 
Quanto ao item 52 - 0 médico que assina atendeu ao falecido? (Tabela 4), verifica-se que das 355 mortes deste GRUPO, 307 (86,5\%) foram hospitalares e dessas $203(66,1 \%)$ o médico que assinou o $A O$ atendeu ao falecido.

As DO cujas causas básicas eram mal definidas e as que estavam classificadas nas causas residuais dos capítulos da CID totalizaram 79 e 25 , respectivamente. Do total das mortes ocorridas no município no periodo analisado (534), estas causas representam ao redor de $20 \%$. Para um município que conta com duas Faculdades de Medicina e ao redor de mil médicos, é um valor considerado alto.

lyda em seu livro "Cem anos de saúde - pública" coloca que, em 1950, 33\% dos óbitos eram classificados como óbitos sem assistência médica e mal definidos, no Brasil. Já se passaram 52 anos e o município de Marília difere em $18,5 \%$ deste número ${ }^{(43)}$

Ao se proceder a análise do GRUPO II - DO com causa básica mal definidas e/ou residuais dos capítulos da CID, verificou-se que em $34 \%$ delas o item "Assistência médica" se encontrava em branco e se somadas com as ignoradas este valor subia para $71,2 \%$ (Tabela 5). Ao compará-lo com o das DOs do GRUPO I (com causas básicas bem definidas), verifica-se que essas apresentaram maior proporção de DO em branco, mas um número muito pequeno de ignoradas, sendo que as duas somadas (em branco e ignoradas) totalizaram $45,4 \%$. A diferença de proporção entre estes dois grupos foi estatisticamente significativa, com Qui - quadrado igual a 20,41 ( $p=0,000006)$.

Ao verificar se havia diferença, do ponto de vista estatístico, quanto ao número de campos deixados em branco, nos certificados de óbito do GRUPO I e do GRUPO II, para as variáveis "cirurgia" e "exame complementar", obteve-se para a primeira variável um Qui - quadrado igual a $10,88(p=0,0009)$ e para a segunda o Qui - quadrado de 52,53 ( $p=0,0000000$ ). Portanto, as diferenças foram todas estatisticamente significativas, mostrando, claramente, o quanto ter DO com causas mal definidas compromete os campos da parte $\mathrm{VI}$, levando, consequentemente, a informações de má qualidade. 
De uma forma geral, no GRUPO II há, em todas as variáveis analisadas, muito mais dados ignorados do que no GRUPO I, o que é de se esperar uma vez que grande parte destas mortes ocorre em domicilio ou poucos instantes após a entrada no hospital. Mas é interessante ressaltar que quando se realizou a investigação em prontuários ou visitas domiciliárias, para verificação de diagnóstico correto ou incorreto, na grande maioria dos casos eram prontuários extensos, com uma gama importante de informações, geralmente em portadores de doenças crônicas que freqüentavam aquele serviço há muitos anos.

Constataram-se, também diferenças importantes entre o GRUPO I e II em relação às variáveis 26 - Local de ocorrência do óbito e a 52 - 0 médico que assina atendeu ao falecido. Foi detectada diferença estatisticamente significativa entre as proporções de DO mal definidas e o fato das pessoas terem morrido no hospital ou no domicílio (Qui - quadrado $=171,75-p=0,0000$ ). Desta maneira, morrer no domicílio pode estar associado a uma DO com causa mal definida. $O$ mesmo ocorreu ao se analisar estatisticamente a diferença entre o médico ter atendido ou não os doentes e as DO serem bem definidas (Qui - quadrado $=79,3$ $-p=0,0000$ ). Portanto, o fato do médico atender o doente pode estar associado a uma DO preenchida com causa bem definida.

Tabela 5- Número e porcentagem de Declarações de Óbito do Grupo II (mal definidas e residuais de capítulo) segundo informações que constam na parte Vl: condições e causas do óbito e item 52 da parte VII : médico.

\begin{tabular}{|c|c|c|c|c|c|c|c|c|}
\hline \multirow{2}{*}{$\begin{array}{l}\text { Informação } \\
\text { Itens da DO }\end{array}$} & \multicolumn{2}{|c|}{ Preenchidas } & \multicolumn{2}{|c|}{ Em branco } & \multicolumn{2}{|c|}{ Ignorada } & \multicolumn{2}{|c|}{ TOTAL } \\
\hline & $\mathrm{N}^{\circ}$ & $\%$ & $N^{\circ}$ & $\%$ & No & $\%$ & $\mathbf{N}^{\circ}$ & $\%$ \\
\hline Assistência médica & 30 & 28,8 & 36 & 34,6 & 38 & 36,6 & 104 & 100 \\
\hline $\begin{array}{l}\text { Exame } \\
\text { complementar }\end{array}$ & 65 & 62,5 & 07 & 6,7 & 32 & 30,8 & 104 & 100 \\
\hline Cirurgia & 75 & 72,1 & 12 & 11,5 & 17 & 16,4 & 104 & 100 \\
\hline Necropsia & 86 & 82,7 & 10 & 9,6 & 8 & 7,7 & 104 & 100 \\
\hline $\begin{array}{l}\text { Causas da morte } \\
\text { Parte I }\end{array}$ & 23 & 22.1 & $81^{1}$ & 77,9 & - & - & 104 & 100 \\
\hline Seqüência lógica & 07 & 6,7 & 98 & 93,3 & - & - & 104 & 100 \\
\hline Tempo & 02 & 1,9 & 102 & 98,1 & - & - & 104 & 100 \\
\hline Médico & 93 & 89,4 & 11 & 10,6 & - & - & 104 & 100 \\
\hline
\end{tabular}

'Este dado se refere à parte I estar preenchida como causa desconhecida 
Nas visitas domiciliares realizadas alguns familiares relataram que, ao conversarem com o médico que constatou o óbito, expuseram o problema de saúde que a pessoa apresentava e em qual serviço esta estava sendo tratada, mas que esta informação não foi levada em conta, gerando até um certo desconforto às pessoas da família quando verificavam que na declaração de óbito constava "causa desconhecida".

O "descaso" com as informações dadas pela família pode se dar por vários motivos. Um deles reside na própria organização da assistência praticada, onde o profissional tem pouco tempo para despender com o doente e seus familiares, principalmente se for um serviço de emergência; em segundo lugar, ainda relacionado à organização da assistência, nas unidades hospitalares, onde ocorreu a maioria das mortes, o Sistema, apesar de informatizado, ainda não permite a disponibilização do prontuário, em tempo hábil, para que a equipe de saúde possa consultá-lo e até averiguar a veracidade das informações dos familiares; um terceiro ponto a ser analisado fica por conta da desinformação, ou melhor pela informação equivocada que o médico só deve preencher a causa de morte se tiver certeza absoluta do diagnóstico; ainda um quarto ponto deve ser discutido, que se refere aos preconceitos que se estruturam ao longo do curso de graduação médico, de que informações quanto ao diagnóstico de patologias só aos médicos pertencem, ou seja os " míseros mortais" não têm acesso a estas, portanto as informações que vêm desta fonte não são confiáveis.

Em trabalho realizado em um hospital público que, segundo Oliveira e Fortes (1997), era de "bom nível técnico", foi verificado que somente $35 \%$ dos doentes idosos tinham recebido alguma informação do corpo médico da instituição em que estavam hospitalizados, sobre o motivo de sua internação( ${ }^{(73)}$.

Torres ${ }^{(96)}$ coloca que discorda veementemente de colegas que colocam que a maioria das pessoas, em função do baixo nivel sócio-econômico, não é capaz de compreender as informações a respeito de seu quadro clínico. Faz uma análise que há, na prática dos profissionais de saúde, três padrões de informações. O primeiro é o padrão da prática profissional onde o médico é que decide quais as vantagens e desvantagens da informação e o quanto e o quê 
deve ser informado. O segundo é o da pessoa razoável, aqui o profissional decide o quê e o quanto uma "pessoa mediana-razoável" precisaria saber sobre a sua saúde e das medidas diagnósticas e terapêuticas. Neste caso o médico precisa criar hipoteticamente esta "pessoa mediana". O padrão subjetivo é a terceira maneira, onde o médico personaliza a informação, ou seja dá a cada um o que cada um necessita e ou suporta. "Contempla as expectativas, interesses e valores de cada paciente".

Nos dois primeiros padrões fica claro que o princípio ético da autonomia do paciente não é respeitado, mas são estes, principalmente o primeiro, que a maioria dos médicos utiliza. Conclui, dizendo que se os doentes não compreendem as informações, a causa reside na inadequação da mesma e não na pretensa incapacidade de compreensão do paciente ${ }^{(96)}$.

É interessante observar que se a familia sabe sobre as doenças da pessoa que veio a morrer, foi com certeza um médico que a informou, mas porque, então, não considerá-la? Para esta análise Chauí levanta um ponto que serve para se pensar a respeito do "descaso" da informação familiar, que é o significado do discurso competente. Segundo a autora o discurso competente é uma "linguagem institucionalmente permitida e autorizada", ou seja as pessoas que o utilizam são reconhecidas como aquelas que tem o "direito de falar e ouvir", é como se dissesse: "não é qualquer um que pode dizer a qualquer outro qualquer coisa em qualquer lugar em qualquer circunstância".

Assim, não considerando a informação da família, o médico está exercendo o seu "direito de falar e ouvir" "institucionalmente autorizado" onde somente este profissional detém o discurso competente da saúde - doença ${ }^{(23)}$. 
Gráfico3: Número de Declarações de Obito de causas básicas do GRUPO II segundo o grau de preenchimento da parte IV e a existência de sequência lógica entre as causas.
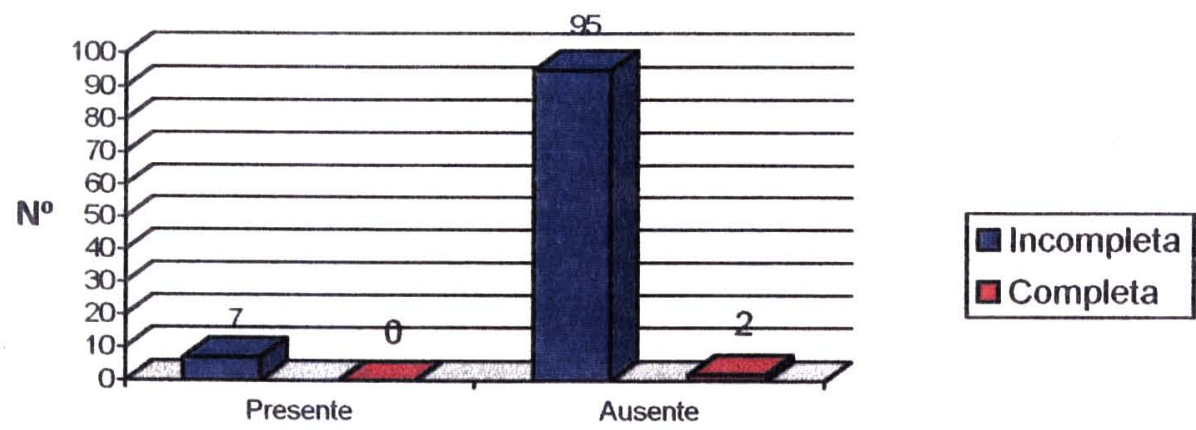

Sequência Lógica

Em trabalho ainda não publicado, Baggio ${ }^{(3)}$ verificou altas sensibilidade $\mathrm{e}$ especificidade na comparação das informações fornecidas por familiares dos falecidos com as que constam de prontuário, no caso de doenças crônicas, principalmente, neoplasias.

Ao serem investigadas as DO do GRUPO II, encontrou-se, para aquelas com causas básicas mal definidas, $100 \%$ incompletas e a mesma porcentagem com seqüência lógica comprometida. Oitenta e quatro porcento dos atestados com causas residuais de capítulo apresentaram- se incompletos e, destes, a maioria (89\%) não tinha seqüência lógica definida (Gráfico 3). Este é outro dado esperado em se tratando de causas mal definidas e residuais de capitulo, pois, não se definindo a causa, a seqüência, obviamente, fica comprometida.

Das DO com causa de morte mal definida, após a investigação, em $81,1 \%$ (64) houve melhora da informação, ou seja deixaram de ser causas desconhecidas para serem bem definidas. Dois e meio porcento passaram a fazer parte das com diagnósticos incompletos (causas residuais de capítulo). Já das DO com causas básicas classificadas como residuais de capítulo, $84 \%$ (21) passaram a ser bem definidas.

Realizando uma série histórica de 9 anos, do número de óbitos com causas básicas mal definidas, no município de Marilia, verificou-se que vem crescendo e o que chama mais atenção é o fato de que, no ano de 1999, a Secretaria 
Municipal de Saúde estruturou um serviço de vigilância de óbito, mas que atua até este momento em grupos especificos, ou seja, investiga as declarações de óbitos de menores de um ano e seleciona casos que são rejeitados pelo programa informatizado utilizado. A influência deste trabalho na diminuição da freqüência dos atestados de óbito com causas mal definidas foi praticamente nula, à medida que no período de 1999 a 2001 estas continuam aumentando (Gráfico 4).

Possivelmente, o trabalho precisa ser ampliado, tanto para a investigaçāo de todas as DO com causas mal definidas e incompletas, quanto para implementar outras atividades junto aos profissionais que preenchem este instrumento.

Gráfico 4 : Proporção (\%) de óbitos por causas mal definidas, em relação ao total de óbitos, no Municipio de Marilia, no periodo de 1993/2001.

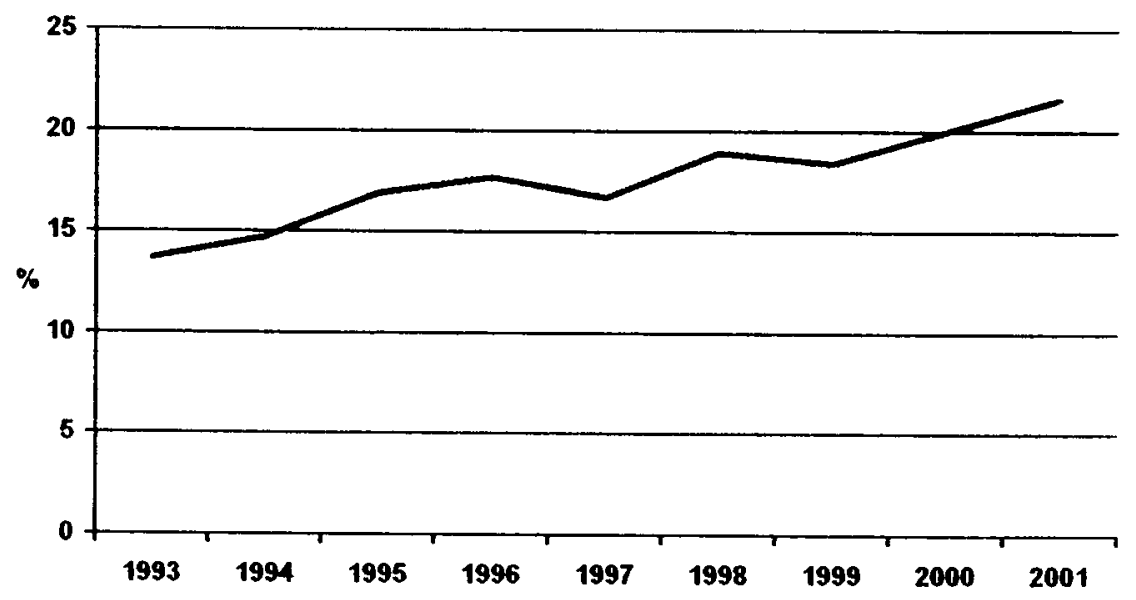

Fonte : DIR - Marilia

As mortes de mulheres em idade fértil, GRUPO III, representaram $3,7 \%$ do total de mortes do periodo investigado. Examinando a parte II das DO deste grupo, observou-se que, a exemplo das do GRUPO I, a "escolaridade" é o item menos assinalado $e$, neste caso, até por serem em menor número, não há nenhuma DO que conste "escolaridade" das mulheres em idade fértil (Tabela 6)

Das 20 declarações de óbito de mulheres de 10 a 49 anos, 2 foram mortes relacionadas à situação de parto e puerpério. Interessante observar que nos atestados de óbito, em questão, na parte IV - Condições e causas do óbito Óbito em Mulheres (item 44) estava assinalado que a morte ocorrera durante o 
puerpério, mas como este dado isoladamente não diz se foi de fato uma morte materna (morte em decorrência de complicações da gravidez, parto, aborto), ele não podia ser levado em conta, como de fato não o foi. Somente após investigação no domicílio e posteriormente de posse dos prontuários destas mulheres é que foi possível constatar que as causas básicas das mortes estavam relacionadas às complicações da gravidez e portanto, configuravam-se como mortes maternas.

Em decorrência deste fato o coeficiente de mortalidade materna no município passou de 61,48/100.000 nascidos vivos (Fundação SEADE - 1999) para $110,3 / 100.000$. Vale ressaltar que as duas mortes foram consideradas na análise pois os óbitos foram trabalhados segundo local de ocorrência e não de residência, mas para recalcular o coeficiente de mortalidade materna levou-se em conta somente uma das mulheres uma vez que a outra não residia em Marília.

Ao verificar o sistema informatizado de mortalidade ora utilizado nacionalmente, observou-se que ele não foi programado para abrir uma "janela" solicitando investigação das causas de morte, caso estes itens fossem assinalados na DO. Esta programação poderia ser interessante para chamar atenção dos profissionais que atuam na avaliação da qualidade da informação de mortalidade.

Tabela 6 - Número e porcentagem de Declaraçōes de Óbito do Grupo Ill: mulheres em idade fértil, segundo informações que constam na parte II: Identificação.

\begin{tabular}{|c|c|c|c|c|c|c|c|c|}
\hline \multirow{2}{*}{$\begin{array}{l}\text { Informaçăo } \\
\text { Itens da DO }\end{array}$} & \multicolumn{2}{|c|}{ Preenchidas } & \multicolumn{2}{|c|}{ Em branco } & \multicolumn{2}{|c|}{ Ignorada } & \multicolumn{2}{|c|}{ TOTAL } \\
\hline & $N^{0}$ & $\%$ & $N^{0}$ & $\%$ & $\mathbf{N}^{0}$ & $\%$ & $\mathbf{N}^{0}$ & $\%$ \\
\hline Tipo de óbito & 20 & 100 & - & - & - & - & 20 & 100 \\
\hline Data & 20 & 100 & - & - & & - & 20 & 100 \\
\hline Idade & 20 & 100 & $1-$ & - & - & - & 20 & 100 \\
\hline Sexo & 20 & 100 & - & - & - & - & 20 & 100 \\
\hline Ocupação & 19 & 95,0 & 1 & 5,0 & - & - & 20 & 100 \\
\hline Estado civil & 19 & 95,0 & 1 & 5,0 & - & - & 20 & 100 \\
\hline Escolaridade & - & - & 18 & 94,7 & 2 & 5,3 & 20 & 100 \\
\hline
\end{tabular}

Marcus et al, estudando a mortalidade materna no município de São Paulo (1995), encontraram que, em 124 mortes maternas, 37,1\% não tinham referência 
deste fato na DO, levando portanto a um Coeficiente de Mortalidade Materna subestimado ${ }^{(54)}$

Os itens especificos para mortes de mulheres em idade fértil se referem à investigação se a morte está ou não relacionada a causas ligadas à gravidez, parto, aborto ou puerpério, portanto é extremamente importante que estes campos estejam devidamente assinalados. Mas o que se verifica é que em mais da metade dos casos (55\%) isto não ocorre. Ao se levar em conta os dados ignorados do item, que questiona sobre a morte durante o puerpério, esta proporção sobe para $60 \%$ de informações desconhecidas (Gráfico 5).

Gráfico 5: Porcentagem de Declarações de Óbito de causas báscias do GRUPO III, segundo o grau de preenchimento da parte VI - Óbitos em Mulheres (item 43 e

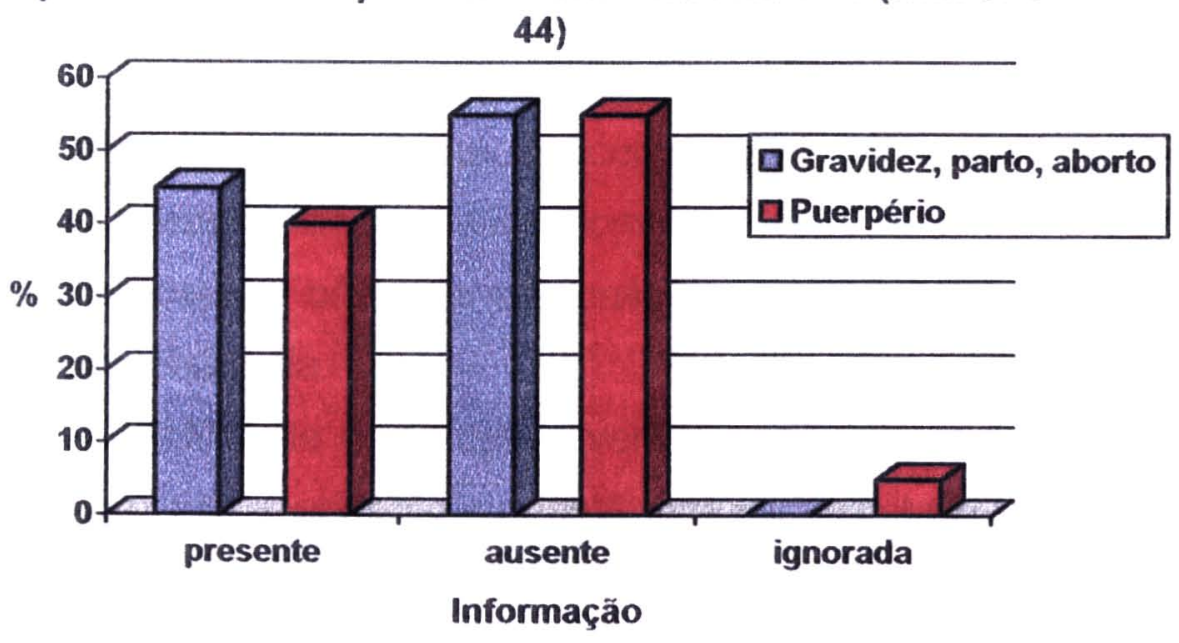

Assim como aponta o trabalho realizado por Siqueira et al, investigando a mortalidade feminina na região sul do município de São Paulo (1999), a ausência destes dados camufla importantes problemas, entre eles a participação do aborto como causa de morte materna ${ }^{(102)}$

Em 35\% das DO de mulheres em idade fértil, não constam informações relativas ao fato de terem recebido assistência médica durante a doença que ocasionou a morte. E aqui, mais uma vez, a variável tempo é a mais negligenciada pelos profissionais que preenchem os atestados de óbito (95\%).

As demais variáveis apresentam falta de informação em cerca de $20 \%$ dos atestados (Tabela 7). 
Tabela 7- Número e porcentagem de Declarações de Óbito do Grupo III (mortes de mulheres em idade fértil) segundo informações que constam na parte VI: condições e causas do óbito e item 52 da parte VII : médico.

\begin{tabular}{|c|c|c|c|c|c|c|c|c|}
\hline \multirow{2}{*}{$\begin{array}{l}\text { Informação } \\
\text { Itens da DO }\end{array}$} & \multicolumn{2}{|c|}{ Preenchidas } & \multicolumn{2}{|c|}{ Em branco } & \multicolumn{2}{|c|}{ Ignorada } & \multicolumn{2}{|c|}{ TOTAL } \\
\hline & $\mathrm{N}^{\circ}$ & $\%$ & $\mathrm{~N}^{0}$ & $\%$ & $\mathrm{~N}^{\circ}$ & $\%$ & $\mathrm{~N}^{0}$ & $\%$ \\
\hline Assistência médica & 13 & 65,0 & 5 & 25,0 & 2 & 10,0 & 20 & 100,0 \\
\hline Exame complementar & 16 & 80,0 & 4 & 20,0 & - & - & 20 & 100,0 \\
\hline Cirurgia & 15 & 75,0 & 4 & 20,0 & 1 & 5,0 & 20 & 100,0 \\
\hline Necropsia & 19 & 95,0 & 1 & 5,0 & - & - & 20 & 100,0 \\
\hline $\begin{array}{l}\text { Causas da morte } \\
\text { Parte I }\end{array}$ & 17 & 85,0 & $2^{1}$ & 10,0 & - & - & 20 & 100,0 \\
\hline Seqüência lógica & 14 & 70,0 & 5 & 25,0 & - & - & 20 & 100,0 \\
\hline Tempo & 1 & 5,0 & 19 & 95,0 & - & - & 20 & 100,0 \\
\hline Médico & 20 & 100 & - & - & - & - & 20 & 100,0 \\
\hline
\end{tabular}

${ }^{1}$ Este dado se refere a parte I estar preenchida como causa mal definida

As declarações completas e incompletas totalizaram 1 caso $(5 \%)$ e 19 casos $(95 \%)$, respectivamente. Das completas, $100 \%$ apresentaram seqüência lógica entre as causas básica e as conseqüentes; das incompletas, $26,3 \%$ não apresentavam seqüência.

Deste GRUPO de declarações verificou-se que em $90 \%$ (18) constava a causa básica correta e, portanto, em $10 \%$ esta causa estava incorreta; verificou-se este fato após investigação domiciliar e/ou dos prontuários dos serviços de saúde.

Há vários trabalhos que investigam as mortes em mulheres em idade fértil, utilizando as DO, e inclusive fazendo análise de qualidade da informação, mas estes enfocam, prioritariamente, as causas de morte e não analisam a existência das diferentes variáveis no atestado de óbito ${ }^{(46,54,102)}$.

No periodo estudado, ocorreram 46 mortes por causas externas e estas se configuram como GRUPO IV, da classificação utilizada neste trabalho. Estas mortes representaram $9 \%$ do total de óbitos.

Atualmente, no Brasil, as causas externas representam a $2^{a}$ causa de morte e a $3^{\text {a }}$ na região sul. As informações da mortalidade por causas externas, como afirma Drumond Jr., contribuem para o desenvolvimento de ações preventivas nas diferentes áreas relacionadas ao fenômeno da violência, para planejamento de 
ações sociais, além de avaliar tendências e acompanhar o impacto das intervenções voltadas para sua redução ${ }^{(28)}$.

Tabela 8- Número e porcentagem de Declaraçōes de Óbito do Grupo IV (mortes por causas externas) segundo informações que constam na parte Vl: condições e causas do óbito e item 52 da parte VII : médico.

\begin{tabular}{|c|c|c|c|c|c|c|}
\hline \multirow{2}{*}{$\begin{array}{l}\text { Informação } \\
\text { Itens da DO } \\
\text { Assistência médica }\end{array}$} & \multicolumn{2}{|c|}{$\begin{array}{l}\text { Existente } \\
N^{\circ}\end{array}$} & \multicolumn{2}{|c|}{ Não existente } & \multicolumn{2}{|c|}{$\begin{array}{l}\text { TOTAL } \\
\mathrm{N}^{\mathbf{0}}\end{array}$} \\
\hline & 14 & 29,2 & 34 & 70,8 & 48 & 100,0 \\
\hline Exame complementar & 34 & 70,8 & 14 & 29,2 & 48 & 100,0 \\
\hline Cirurgia & 34 & 70,8 & 14 & 29,2 & 48 & 100,0 \\
\hline Necropsia & 46 & 95,8 & 2 & 4,2 & 48 & 100,0 \\
\hline $\begin{array}{l}\text { Causas da morte } \\
\text { Parte I }\end{array}$ & 47 & 97,9 & 11 & 2,1 & 48 & 100,0 \\
\hline Seqüência lógica & 35 & 72,9 & 13 & 27,1 & 48 & 100,0 \\
\hline Tempo & - & - & 48 & 100 & 48 & 100,0 \\
\hline Médico & 46 & 95,8 & 2 & 4,2 & 48 & 100,0 \\
\hline
\end{tabular}

'Este dado se refere à parte I estar preenchida como causa residual de capítulo .

O percentual de DO cujo item- Assistência médica ficou em branco foi igual a 70,8\%, somente comparável ao GRUPO II das causas mal definidas e residuais de capítulo, quando somadas às ignoradas (Gráfico 6). As variáveis "exame complementar" e "cirurgia" não estão assinaladas em quase 30\% das DO; e ainda, em $100 \%$ dos atestados não consta o item "tempo". De fato esta variável (tempo), na maioria dos casos de morte por causas externas, fica comprometida, mas em alguns deles as pessoas foram hospitalizadas em decorrência do "acidente" vindo a morrer após certo tempo, sendo possivel, então, preencher esta variável.

Causa estranheza o fato de que, somente, $85,4 \%$ destes atestados foram assinados por médicos legistas do Instituto Médico Legal (IML), por dois motivos, - primeiro é que sendo preenchido pelo IML este órgão deveria ser o primeiro a zelar pela qualidade da informação prestada e, segundo, o IML deveria ter preenchido todos estes atestados, já que é a instituição que legalmente responde pelas declarações de óbito em casos de morte por causas externas. 
Necessário ressaltar o fato que em três DO aparecia como diagnóstico no campo das causas contribuintes fratura de fêmur e quem assinou o atestado foi o médico, geralmente o ortopedista, que cuidou do doente e não os médicos legistas, como deveria ser o procedimento correto. Este evento demonstra a falta de conhecimento dos profissionais quanto ao procedimento adequado nestes casos. A seqüência lógica na cadeia de causas que levaram o doente a morrer ficou comprometida em 27,1\%. Tal valor se deve ao fato de que, mesmo o IML atestando o óbito, este coloca na parte I somente a causa imediata e as lesões.

Possivelmente este dado reflete a forma de trabalho do IML, uma vez que na investigação destes óbitos verificou-se que em grande parte dos casos os médicos legistas não fazem necropsia, realizam, somente, exame externo para expedirem seus laudos.

Das declarações de óbito deste GRUPO, 100\% (48) estavam incompletas. Destas, $72,9 \%$ (35) apresentavam seqüência lógica, contra $27,1 \%$ (13) que estavam sem seqüência adequada (Gráfico 6). As 48 declarações analisadas foram classificadas como incompletas em função da variável "tempo..", que estava em branco em $100 \%$ dos atestados.

Gráfico 6:Porcentagem de Declarações de Óbito de causas externas do GRUPO IV incompletas segundo a existência de sequência lógica entre as causas.

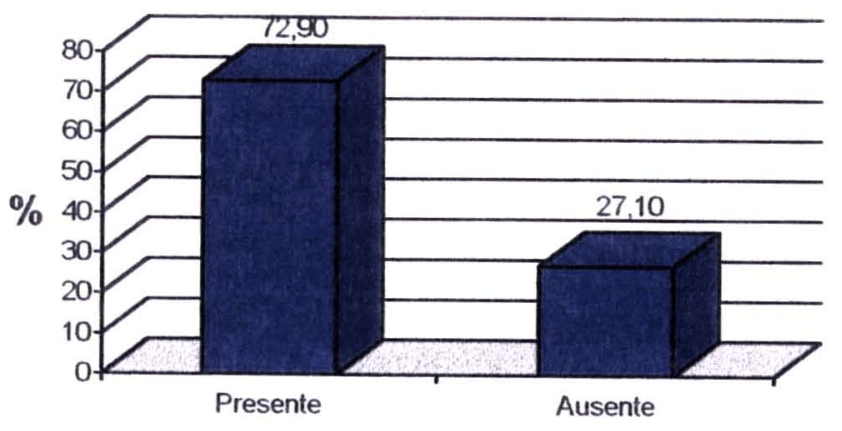

Sequência Lógica 
Após investigação nos arquivos do Instituto Médico Legal (IML), nos boletins de ocorrência dos distritos policiais, $68,7 \%$ dos atestados foram considerados corretos e $8,3 \%$ incorretos.

Alguns não estavam incorretos mas a investigação realizada melhorou a informação. Isto é, em algumas declarações não constava se a pessoa que veio a morrer era passageiro ou motorista no caso de veículo à motor; de outra sorte, se era uma morte por acidente de trânsito, a DO não deixava claro se havia sido, ou não, um caso de atropelamento etc. Estes atestados foram considerados incompletos, dos 48 casos de causas externas havia 14 mortes que se encaixavam neste subgrupo; destes, $28,6 \%$ permaneceram incompletos e a maioria $(57,1 \%)$ passou a ter a informação completa e bem determinada, após a investigação.

Para mortes por causas externas há uma parte específica na DO, de forma que seja possivel obter dados mais consistentes e adicionais deste tipo de morte. O preenchimento deste campo é relativamente bom, com exceção das variáveis de acidente de trabalho e descrição do evento, ficando estes itens em branco em $33,3 \%$ e $52,2 \%$, respectivamente.

O campo para "descrição do evento" poderia melhorar muito a informação em relação as estas mortes em geral, mas a contribuição é pequena quando ele não é preenchido ( $52,2 \%$ dos casos) (Tabela 9 ).

Mello Jorge discute que há dificuldade em se estabelecer politicas de intervenção uma vez que o conhecimento das causas externas em geral e dos homicídios em particular é precário. Por outros tipos de estudos sabe-se que a maioria dos homicídios ocorre utilizando arma de fogo e sua incidência é maior em grupos sociais menos privilegiados quando comparados com outras causas violentas ${ }^{(58)}$.

Ter a informação se a morte estava relacionada ao trabalho seria de suma importância, tanto para propor medidas de intervenção no campo da saúde, como para intervir do ponto de vista legal. 
Tabela 9- Número e porcentagem de Declarações de Óbito do Grupo IV (mortes por causas externas) segundo informações que constam na parte VIII: causas externas

\begin{tabular}{|c|c|c|c|c|c|c|c|c|}
\hline \multirow{2}{*}{$\begin{array}{l}\text { Informação } \\
\text { Itens da DO }\end{array}$} & \multicolumn{2}{|c|}{ Preenchidas } & \multicolumn{2}{|c|}{ Em branco } & \multicolumn{2}{|c|}{ Ignorada } & \multicolumn{2}{|c|}{ TOTAL } \\
\hline & $\mathrm{N}^{\circ}$ & $\%$ & $\mathrm{~N}^{\circ}$ & $\%$ & $\mathrm{~N}^{0}$ & $\%$ & & $\%$ \\
\hline Tipo & 43 & 91,2 & 3 & 4,4 & 2 & 4,4 & 48 & 100,0 \\
\hline Acidente do trabalho & 16 & 35,5 & 18 & 33,3 & 14 & 31,1 & 48 & 100,0 \\
\hline Fonte de informação & 40 & 83,3 & 8 & 16,6 & - & - & 48 & 100,0 \\
\hline Descrição do evento & 21 & 43,7 & 27 & 56,2 & $1-$ & - & 48 & 100,0 \\
\hline $\begin{array}{l}\text { Ocorrência em via } \\
\text { pública }\end{array}$ & 8 & 16,6 & 40 & 83,3 & - & - & 48 & 100,0 \\
\hline
\end{tabular}

O campo para ocorrência em via pública ficou em branco em $83 \%$ das declarações apesar da maioria dos acidentes ocorrerem na via pública, mas nem sempre a morte se deu neste local. Portanto, este fato pode refletir o entendimento que os legistas têm deste item.

As DO classificadas no GRUPO V - Mortes por doenças presumíveis de AIDS - representaram $3,2 \%$ das relativas às mortes que ocorreram no município, no período estudado.

Interessante verificar que as DO com menos campos em branco na parte VI - Condições e causas do óbito, estão neste GRUPO. Pode explicar este achado o fato de que, das 18 pessoas que morreram por causas presumíveis de AIDS, em onze delas o médico que assinou a DO foi o mesmo que atendeu o doente. Mas, mesmo tendo valores menores, a falta de preenchimento do "tempo", da variável "assistência médica" e não apresentar uma seqüência lógica continuam sendo os maiores problemas, a exemplo dos demais GRUPOS (Tabela 10). 
Tabela 10- Número e porcentagem de Declarações de Óbito do Grupo V (mortes por causas presumiveis de aids) segundo informações que constam na parte Vi: condições e causas do óbito e item 52 da parte VII : médico.

\begin{tabular}{|c|c|c|c|c|c|c|c|}
\hline \multirow{3}{*}{$\begin{array}{l}\begin{array}{c}\text { Informação } \\
\text { Itens da DO }\end{array} \\
\text { Assistência médica }\end{array}$} & \multirow{2}{*}{\multicolumn{2}{|c|}{$\begin{array}{ll}\text { Existente } \\
\text { N }^{0}\end{array}$}} & \multicolumn{2}{|c|}{ Não existente } & \multirow{2}{*}{\multicolumn{2}{|c|}{$\begin{array}{l}\text { TOTAL } \\
\text { No }^{0}\end{array}$}} & \multirow[b]{2}{*}{$\%$} \\
\hline & & & $\mathbf{N}^{\circ}$ & $\%$ & & & \\
\hline & 13 & 72,2 & 5 & 27,8 & 18 & 100,0 & \\
\hline Exame complementar & 16 & 88,9 & 2 & 11,1 & 18 & 100,0 & \\
\hline Cirurgia & 16 & 88,9 & 2 & 11,1 & 18 & 100,0 & \\
\hline Necropsia & 16 & 88,9 & 2 & 11,1 & 18 & 100,0 & \\
\hline $\begin{array}{l}\text { Causas da morte } \\
\text { Parte I }\end{array}$ & 18 & 100 & - & - & 18 & 100,0 & \\
\hline Sequiência lógica & 14 & 77,8 & 4 & 22,2 & 18 & 100,0 & \\
\hline Tempo & 1 & 5,6 & 17 & 94,4 & 18 & 100,0 & \\
\hline Médico & 17 & 94,5 & 1 & 5,5 & 18 & 100,0 & \\
\hline
\end{tabular}

Todas declarações de óbito estavam incompletas, uma vez que o campo de tempo não foi preenchido. Em $77,7 \%$ (14) pode-se verificar a existência de seqüência entre as causas básica e as consequenciais e em 22,2\% (4) esta não foi constatada (Gráfico 7).

\begin{abstract}
Gráfico7:Porcentagem de Declarações de Óbito de causas presumiveis de AIDS do GRUPO V incompletas segundo a existência de sequência lógica entre as causas.
\end{abstract}

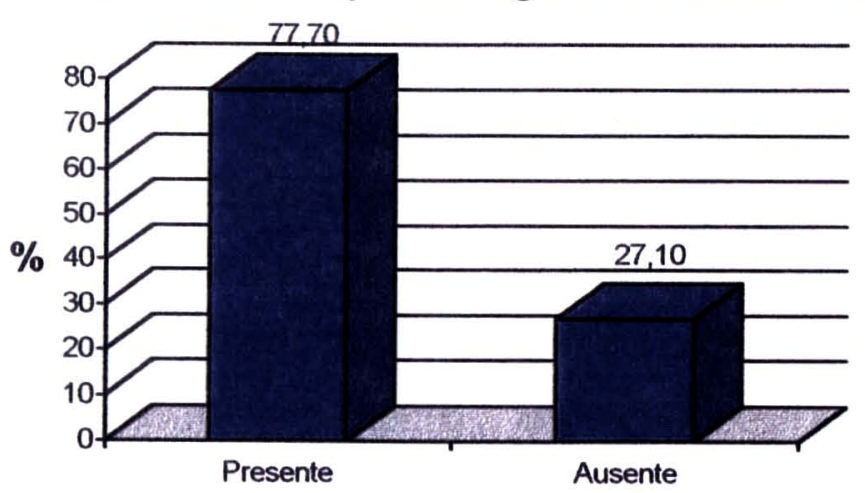

Sequência Lógica

Em somente um caso o diagnóstico estava incorreto, ou seja era uma pessoa cuja causa básica de morte era AIDS mas esta não constava da DO. Interessante observar que este caso foi identificado a partir de uma lista de 
doenças que podem cursar na vigência de AIDS. Apesar de ser somente um caso, instituir esta lista nos serviços de investigação de mortalidade pode ser uma boa prática.

Como se pode verificar as declarações de óbito no município de Marília deixam a desejar em vários pontos. Obviamente, este fato não é privilégio desta cidade.

Mas o que fazer? Há muitos anos, várias organizações e aqui no Brasil o Centro Brasileiro de Classificação de Doenças vêm trabalhando exaustivamente na divulgação das informaçōes necessárias para o preenchimento adequado da DO, tanto por intermédio de informes técnicos como participando de eventos científicos, palestras para médicos, entre outras atividades. Claro que muita coisa já mudou, mas ainda há um bom caminho a percorrer.

E qual será a melhor forma, o melhor caminho? Entender quais os pensamentos que os médicos possuem a respeito da DO pode ser uma maneira de melhor selecionar as estratégias para futuras intervençōes. É com esta intenção que se passa à segunda fase deste trabalho.

\section{IV.2. SEGUNDA FASE : AVALIAÇÃO QUALITATIVA}

Nesta fase os 25 médicos entrevistados apresentaram o seguinte perfil: média de idade de 43 anos variando de 25 a 64 anos, sendo que $68 \%$ deles estavam na faixa etária de 31 a 50 concentrando-se (48\%) entre 41 e 50 anos, a maioria (76\%) tinha mais de 10 anos do término do curso de graduação com uma média de tempo de formado de 18,1 anos com uma amplitude de 5 meses a 39 anos e $12 \%$ eram mulheres.

Grande parte dos entrevistados (28\%) é formada por médicos que atuam nos prontos-socorros dos hospitais do município. Os demais são profissionais que trabalham com pacientes oncológicos, tanto clínicos como cirurgiões, médicos legistas e médicos residentes de primeiro e segundo ano da clínica médica do 
Hospital Universitário, que têm a responsabilidade de preencher os atestados de óbito de pessoas que morreram em domicílio e que, teoricamente, não estavam sendo acompanhadas por nenhum médico, seja do serviço público de saúde, seja no privado.

Frente à pergunta1 identificou-se nas expressões-chave, três idéiascentrais (IC) que estão descritas em três discursos do sujeito coletivo (DSC), descritos abaixo:

\section{Pergunta 1-Como você se sente afetivamente preenchendo uma declaração de óbito? Como é isto para você?}

\section{Idéias Centrais (IC)}

1-Preencher o AO faz parte do trabalho médico, é uma atividade técnica e uma obrigação, porisso não há nenhum sentimento envolvido, mesmo porque a morte é um evento natural.

2- Depende da idade do paciente, do local de atendimento, do vínculo que se estabeleceu com ele e sua família, e da patologia de base que ele apresentava. 3- É ruim, são vários sentimentos: tristeza, perda, pena, impotência, dificuldade de se lidar com a morte, relacionados ao questionamento de ter feito tudo o que podia pelo paciente.

\section{IC 1}

Depende da idade do paciente, do local de atendimento, do vinculo que se estabeleceu com ele e sua família, e da patologia de base que ele apresentava.

\section{Discurso do Sujeito Coletivo 1 ( DSC1)}

Toda vez que eu preencho um atestado, normalmente são meus clientes, pacientes que eu cuidei na enfermaria e que por tudo isso, você cria um vínculo médico - paciente .... fica mais de 4 dias, então você tem um envolvimento com a família, com o próprio doente, neste caso eu tenho assim, um pouco de pena, me dá um pouco de depressão. Por exemplo: paciente asmático, "Depeótico" que vem continuamente ao pronto-socorro ou àqueles cancerosos que vem normalmente ao pronto-socorro, estes aí ... o dia que morrerem nós vamos sentir...

Porisso, eu quero ter mais cuidado para preencher porque se não tiver preenchido de forma adequada a família desses pacientes vão ter dificuldade para conseguir seguro.

Se eu prestei assistência médica para ele, ora sinto com a missão cumprida, de ter feito o que eu pude pelo paciente, ora tem o infortúnio de não ter conseguido 
fazer tudo o que podia.

Já outros atestados, eu não sinto nada, porque eu sabia que ele entrou para morrer, não tinha o que fazer, assim como os pacientes do IML, eles não têm nenhum significado afetivo, a não ser que seja criança ou alguém que você conheça.

Quando no plantão, chega o paciente que foi a óbito em casa, a gente assina como morte sem assistência médica; assim, em termos afetivos eu não sinto nada, porque são pessoas que eu não conheço, teve caso que eu.... nem sabia o nome do doente,.... eu não falei nem oi para o paciente. Evidentemente, que o constrangimento não é tanto, né? Porque a gente não fez um laço de... relação médico - paciente mesmo, a gente é burocrata, pura e simplesmente, porque você atende um paciente no sistema público de saúde e o seu objetivo é dar o atestado de óbito.

Desta forma, têm dois tipos de atestado que eu acho que existe. O primeiro, eu tenho o atestado do paciente, que é um velho.... ele vai morrer tem o histórico de um câncer generalizado, e aí ele morreu...aquilo lá para assinar o atestado de óbito..., não é uma coisa que traz tristeza para mim, tá? É indiferente... E o outro atestado, é de acidentes de gente jovem que morrem aqui, uma pessoa que não tinha nada, tinha uma vida inteira.......... Dói bastante...

Da mesma forma, se vocé pega uma pessoa jovem, com uma neoplasia, trinta anos em fase terminal, você sente... Também se chegar um jovem em broncoespasmo.... é triste para assinar o atestado de óbito. Não só por ter morrido de uma patologia tão (simples) mas também porque daria para se evitar. Os pacientes sofrem muito, normalmente são diabéticos, cardiopatas, hipertensos de longa data, com lesões não só de membros mas também sistêmicas, às vezes a morte vem a ser até um alivio e a gente se sente aliviado quando eles falecem. Por isso existem pacientes que a gente usa o termo descansar e não morrer...

Cada caso é um caso. Depende: do local em que eu estou, se é aqui na emergência ou se é na UTI.

\section{IC2}

Preencher o AO faz parte do trabalho médico, é uma atividade técnica e uma obrigação, porisso não há nenhum sentimento envolvido, mesmo porque a morte um evento natural.

\section{DSC2}

Não sinto nada. Quer dizer, faz parte do trabalho, não tem emoção. Para mim é indiferente, eu preencho aquilo ali como uma coisa natural. É mais um obrigação técnica do médico, quando o doente morre eu tenho que fazer isto. Para mim é familiar, devido a muitos anos... Portanto a gente tá preparado. Na residência a gente via muito paciente ruim, falecido. E você passa a ver a morte como um evento natural, um evento que a gente não consegue escapar, né? Acho que a parte afetiva fica de lado, entendeu? 


\section{IC3}

É ruim, são vários sentimentos: tristeza, perda, pena, impotência, dificuldade de se lidar com a morte, relacionados ao questionamento de ter feito tudo o que podia pelo paciente.

\section{DSC3}

No momento de você assinar o AO, estas coisas acontecem, ou seja há uma sensação de perda, uma vez que os meus óbitos são de pacientes conhecidos, habitualmente crônicos, portanto, de longa convivência.

É quando me sinto impotente eu descobri naquela hora que eu não sou nada... Me sinto muito mal. Inicialmente, Quando eu comecei como(médico).. ao me deparar com a morte sempre era, um pouco deprimente, mas com o tempo, você... se habitua um pouco. O único fato que a gente não consegue deixar de, às vezes, se emocionar um pouco é criança. Quando você perde uma criança, que você conviveu mais é como se fosse uma perda irreparável... eu, ainda, não assino $A O$ sem doer.

É uma sensação aonde você questiona, se você fez todo possivel por aquele paciente , se poderia ter tido estratégias terapêuticas diferentes daquela que você assumiu, ou o que poderia ter feito a mais, ou ainda no que eu posso ter falhado, porque na verdade o óbito tem um valor qualitativo no seu trabalho então há necessidade de você estar analisando sempre.

Quando eu percebo que poderia ter feito algo para evitar e eu não agi a tempo, aí eu não fico bem, principalmente se não era grave.

Mas por mais grave que seja a doença é sempre um atestado de óbito, a gente não quer,... e a nossa função é essa mesmo, né? Por isso que toda pessoa viva que chega é uma vida em potencial, que a gente tem que salvar.

Eu fico chateado porque a gente sempre se coloca no lugar da família e do doente, fico pensando, como é que a família tá encarando isto, então, eu fico meio constrangido de assinar o atestado, é uma coisa dura, uma sensação triste.

A construção dos DSC na pergunta 1 , em torno de três eixos de representações, deveu-se ao fato de que os entrevistados logo no início da conversa colocaram a idéia central trabalhada, ou seja, a frase começou com: Depende, ou É ruim ( ou sentimentos afins), ou ainda, não sinto nada.

No primeiro DSC, a IC traz em seu bojo a indiferença ou como alguns colocaram " faz parte do trabalho médico", "é uma coisa naturar" . Interessante perceber que "essa coisa naturaf" vai se construindo ao longo do processo de pósgraduação, principalmente, na residência médica onde se coloca a "parte afetiva de ladon. 
O segundo discurso elaborado apresentou como IC que o seu sentimento no momento do preenchimento da DO dependia de vários fatores.

Chama muita atenção a valorização da juventude como um fator de mobilização para o profissional. Quando o doente é uma criança ou um jovem o sentimento de perda é maior, ou está presente. Mas quando é um idoso, principalmente se apresenta uma doença terminal, a morte sensibiliza menos, geralmente se sente aliviado, particularmente se este apresentar várias patologias concomitantes que estão resultando em sofrimento e dor.

Neste segundo discurso já aparece a interferência da forma de trabalho do médico, ou seja, o sentimento ocorre com mais intensidade quando se tem um vínculo com o doente. Nestes casos, o médico o caracteriza como "meu doente". Observa-se ainda que com estes doentes há uma preocupação com as respectivas familias, ocorrendo o inverso com os doentes "institucionais". Porém, mesmo com estes últimos, se o tempo de convivência é maior os médicos se envolvem mais.

Fica evidente a pequena mobilização afetiva quando o preenchimento da DO refere-se a pessoas que chegam ao Serviço de Urgência da cidade, já mortos ou vindo a morrer momentos depois da entrada ao hospital. Neste caso, fica semelhante ao que ocorre com os falecidos por causas externas que foram submetidos à necropsia pelo IML.

O fato de não ter conhecido a pessoa que veio a falecer, "não ter falado nem or", faz com que o médico se sinta um "burocrata... pura e simplesmente" e isto ocorre quando ele atende "um paciente no serviço público de saúde e o seu objetivo é dar o atestado de óbito....".

A indiferença só é rompida quando os acidentes acometem pessoas jovens - "é um doente doloroso" - e também quando se defrontam com mortes de pessoas com patologias, aparentemente, simples como uma "crise de broncoespasmo", mas mesmo neste caso o fato de ser "jovem" tem um peso importante. 
Já no terceiro discurso, este grupo de médicos assume com muito despojamento os vários sentimentos que vêm à tona ao se defrontarem com a morte, onde a DO é o seu instrumento concreto.

Um deles coloca: "..eu nunca consegui encarar a morte como NÃO sendo uma coisa ruim..." demonstrando a dificuldade em encarar a morte e possivelmente esta dificuldade interferirá, não só no preenchimento da DO como no próprio cuidado despendido ao doente e seus familiares.

Há uma sensação de perda, impotência - "eu descobri naquela hora que eu não sou nada" - depressão, principalmente quando o médico pressente que poderia ter feito algo mais. $E$ ao se questionar reconhece o valor da DO para avaliação da qualidade de seu trabalho.

Aqui também, as crianças, principalmente as que sofreram acidentes, e o vínculo que se tem com o doente, são lembrados como capazes de afetar mais os profissionais.

Ainda, presente neste discurso, está a interferência do processo de trabalho a que o médico é submetido, uma vez que no início da carreira "me deparar com a morte sempre era um pouco deprimente, mas com o tempo você .... se habitua um pouco"

Às vezes o tempo ainda não foi o suficiente para que ele se "acostume" "...eu ainda não assino uma DO sem doer... ". Esta fala passa a idéia que o médico espera que algum dia ele possa assinar um atestado sem "doer".

Como a pergunta feita inicialmente referia-se ao sentimento afetivo no momento do preenchimento da DO, possivelmente os fatores apontados podem influenciar na qualidade do preenchimento. 


\section{Pergunta 2 - Onde você aprendeu a preencher atestado de óbito? Conta como foi isto}

\section{Idéias Centrais}

1- Teoricamente aprendi na medicina preventiva elou medicina legal, mas foi pouco, acaba se perdendo pois não se pratica já que é em momento inadequado.

2- Aprendi na residência médica, com os R2, e nos cursos de pós graduaçãol especialização.

3- Aprendi com a pressão da prática, ora em conversas com quem transcreve as DO e com colegas mais antigos, utilizando o próprio impresso como guia, ora utilizando o manual, mesmo assim tenho dúvidas.

\section{IC1}

1- Teoricamente aprendi na medicina preventiva elou medicina legal, mas foi pouco, acaba se perdendo pois não se pratica já que é em momento inadequado.

\section{DSC 1}

Teoricamente, eu tive um aprendizado na graduação, no curso de medicina preventiva e tivemos um revisão disso no curso de medicina legal. Mas como eu fiquei um tempo sem fazer, isto acaba se perdendo um pouco, você acaba esquecendo; porque quando você é estudante você não preenche Atestado de Óbito. Também a escola onienta de uma maneira pobre, foi só uma passada, eu nem me lembro direito que matéria que era. $A$ informação que você tem para isto foi feita em um momento inadequado, ainda no curso básico e, então, fica muito dissociada da questão da prática. 


\section{IC2}

Aprendi na residência médica, com os R2, e nos cursos de pós graduação especialização.

\section{DSC 2}

Eu aprendi na residência médica, a gente teve muita informação antes de começar a residência, funcionamento do banco de sangue, atestado de óbito, necropsia, toda essa parte. No início do $R 1$ você tem uma reunião com o diretor clínico que nos orienta como faz o preenchimento do atestado de óbito, levando em consideração a causa principal que levou ao obito e as causas secundárias que estão diretamente ligadas à principal. Mas, na verdade, quem foram os grandes professores foram os residentes que te pegavam ali, literalmente a caneta na mão e explicavam. Porque a gente acaba praticando aqui na residência, principalmente no primeiro ano que a gente põe a mão na massa mesmo. O que eu tinha dúvida eu fui perguntando para o pessoal mais experiente para ver o que eu seguia na ordem. E até, nós residentes, escrevemos um artigo sobre preenchimento de AO para a revista da Escola Paulista de Medicina. Mas na realidade verdadeira que eu aprendi a preencher $A O$ quando fiz o curso de saúde - pública

\section{IC3}

Aprendi com a pressão da prática, ora em conversas com quem transcreve as DO e com colegas mais antigos, utilizando o próprio impresso como guia, ora utilizando o manual, mesmo assim tenho dúvidas.

\section{DSC 3}

Foi na pressão da prática mesmo, preenchia pelo que estava escrito no impresso só, de acordo com uma seqüência lógica. E nós fizemos isso e achamos que estava muito bom, depois a gente teve que fazer algumas reciclagens, nada como agora que a gente tem o manual, né? Na verdade, aprendi fazendo, nunca ninguém me ensinou, ninguém sentou comigo e falou é assim que você tem que fazer; eu não tive isso na Faculdade, e nem na residência. No começo da minha vida profissional foi de orelhada. Mas alguém me ensinou, alguém que tava na minha frente, eles que me mostraram como é que preenchia e depois com o tempo eu fui perguntando algumas coisas... mas hoje por exemplo, acho que consigo entender mais ele, do que antes, porque antes eu preenchia ... hoje, eu sou meio crítico, mas tem algumas coisas que eu não entendo por que eu coloco. E na prática eu tive um livro, uma orientação, no curso de medicina legal , que eu usei muito, o do Ruy Laurenti.

Mas, não sei se no quarto ou quinto ano a gente, também, ganha aquele livrinho , e que tem a forma de preencher corretamente e às vezes no R1 a gente acaba nem sabendo se estava preenchendo correto ou não. Além disso, com as 
orientações que a gente tem tido durante os anos em conversa com quem faz o controle da transcrição dos dados do atestado na cidade.

Quanto ao aprendizado do preenchimento da DO, também, puderam ser identificadas três ICs.

A primeira leva ao DSC do aprendizado teórico; a maioria lembra das aulas, mas como sendo insuficientes, e creditam esta insuficiência ao "momento inadequado", desvinculadas da prática e como fica "um tempo sem fazer, isto acaba se perdendo um pouco".

As atividades didáticas apontadas foram ministradas pela medicina preventiva e ou medicina legal, áreas de conhecimento, tradicionalmente, identificadas durante o curso de graduação, pelos alunos, como sendo de menor relevância em relação às cadeiras clínicas, segundo relatos de experiências de docentes destas áreas.

O DSC2 deixa claro que a residência ou cursos de especialização têm um papel fundamental neste aprendizado. Chama atenção que os grandes mestres são os residentes dos anos mais adiantados. E quando a "... a gente põe a mão na massa mesmo..." verifica-se uma valorização da prática no processo de aprendizado. Este fato chama atenção pois grande parte das escolas médicas tem internato nos dois últimos anos, mas estes parecem que não possibilitam este tipo de atuação que fica, então, reservada aos médicos residentes.

Também escrever artigos a respeito do tema pode ser uma boa estratégia para se aprender.

O terceiro discurso está centrado na "pressão da prática", a diferença entre os discursos 2 e 3 refere-se, basicamente, que aqui os médicos não se referiram a cursos de especialização e/ou residência médica, mas sim à atividade cotidiana de ser médico e de ter que preencher DO. Portanto, para estes profissionais, a maior contribuição para o aprendizado foi dada pelos colegas mais antigos e pelo modelo de DO utilizado que é auto explicativo, principalmente no campo VIcondições e causas do óbito. Caso a interpretação do impresso seja inadequada ou "...alguém que tava na minha frente..." tenha uma prática de 
preenchimento de DO equivocada, houve e continuará havendo equívocos nesta atividade.

Os médicos apontam aqui a importância do Manual de Preenchimento de AO organizado por Laurenti. Parece que fazem uma certa confusão entre o Manual de Preenchimento do Ministério da Saúde e a publicação do Centro Brasileiro de Classificação de Doenças - O Atestado de Óbito - este sim organizado por Laurenti.

Também lembraram a importância, neste processo de aprendizagem, de quem lida com as DO no município, que desde o final de 1999 vem entrando em contato com os profissionais discutindo a melhor forma de se preencher este instrumento.

\section{Pergunta 3 - Você tem uma rotina de trabalho, não é? Preencher a DO faz parte desta rotina, não é? Esta rotina facilita ou dificulta o preenchimento do atestado de óbito? Fale um pouco sobre isto.}

\section{Idéias - Centrais}

1- Dificulta porque o volume de trabalho é muito grande, não dá para parar e pensar e se erra não tem como corrigir, a parte burocrática atrapalha, além disso há mortes domiciliares que a rotina de preenchimento é agressiva e assusta à medida que não se conhece o paciente e não se sabe se a morte foi por uma doença orgânica

2 - A rotina de trabalho não atrapalha, em alguns aspectos até facilita, isto é quando a morte é hospitalar, se conhece o paciente, năo se tem dificuldade para preencher o AO, com fácil acesso ao impresso

3- A dificuldade não é a rotina, é preencher sem saber a causa imediata do óbito.

4 -É indiferente pois além de ser um papel do médico, estou sempre presente quando ocorre e é um evento até certo ponto previsto pois os doentes são crônicos 
Dificulta porque o volume de trabalho é muito grande, não dá para parar e pensar e se erra não tem como corrigir, a parte burocrática atrapalha, além disso há mortes domiciliares que a rotina de preenchimento é agressiva e assusta à medida que não se conhece o paciente e não se sabe se a morte foi por uma doença orgânica

\section{DSC1}

A rotina de trabalho acho que dificulta e muito, pois daí fica uma correria..., ó tem que preencher logo, e aquilo é um documento... a gente tá super em dúvida em relação ao preenchimento. Às vezes você preenche correndo. Na minha forma de trabalhar não tenho muito tempo, então, o AO se torna um problema se eu tenho que me deslocar da onde eu tô para ir até o hospital e assinar o $A O$, muitas vezes a família pega o $A O$ e vai até onde eu tô. Eu preencho os $A O$ quando eu estou indo ver os doentes internados;... eu vou para prescrever e examinar pacientes internados, neste meio tempo eu faço os $A O$.

O preenchimento do atestado é complicado não só por parte do cabeçalho, que geralmente é o hospital, o que eu sinto é que muitas vezes eu tenho que repetir o AO porque eu preenchi errado, esqueci um campo ou o pessoal trocou a data ou trocou a hora, trocou o nome e eu tenho que refazer. Checo a parte da identificação. Aqui no pronto-socorro é mais difícil... , tem dia que tem um volume gigantesco de atendimento. Para você parar, para preencher um atestado de óbito é... Preenche, coloca ali, rapidinho, né? Isso faz com que você às vezes coloque o óbito... Depois que você erra.. Precisa preencher tudo de novo ...Não tem como.... não pode passar um errorex..., e escreve em cima, daí, a moça que preenche diz: Ah! tem que preencher de novo? Não dá para deixar assim?.....aí, você observa, esta patologia dá para passar, se você erra a primeira não tem jeito , não tem escolha, se você errar a segunda ou terceira você deixa passar.

O nosso problema é que a própria polícia é negligente na emissão das requisições, então vem nome errado, vem nome de familiar errado, vem... data de nascimento errado... No hospital normalmente o serviço social preenche a DO, e sobra para nós só o atestado, no IML não, no IML preenchemos de cabo a rabo, então ai fica mais....(complicado)

Mas falando em termos práticos, tem toda uma parte burocrática que às vezes atrasa este tipo de serviço. Aí tem que preencher a ficha, a aí esta ficha vai para a moça da internação e, ai ela que bate o atestado de óbito, entendeu? Ai chega 8 horas ainda não trouxeram para eu preencher.

Agora a parte que eu sinto falta ...é de não ter um serviço de verificação de óbito porque são pacientes que nós não conhecemos direito. Sempre que o paciente tem atendimento no hospital a gente pede a pasta porque a gente preenche na causa mortis, "morte sem assistência médica" e risca todo o resto preenchendo os dois parâmetros de baixo de doenças associadas mais de acordo com o prontuário. Eu tenho bastante medo, de não ter sido uma morte decorrente de uma doença orgânica, e sim uma morte por trauma ou uma morte por agressão, 
né? Se for uma morte por agressão .. em termos de ser um documento ...estou subestimando as coisas, mas como você é o plantonista, este paciente não tinha médico, não existe um serviço de verificação de óbito funcionando, eles falam que o plantonista tem que assinar isso daí.

Mas quando eu vejo paciente caquético, que chega até com sonda, às vezes com ileostomia ai eu já não me preocupo tanto... me preocupo mais em verificar o que tem na pasta, de antecedentes para poder acrescentar lá.

Mas eu já tive casos, de ter um pouco mais dificuldade quando, a morte é domiciliar acho uma coisa extremamente ruim. Você tem um óbito de um paciente seu que faleceu em domicilio então, você tem que fazer um pedido formal pro hospital, para o hospital te fornecer este $A O$, ai o médico tem que ir até o hospital para preencher o atestado de óbito lá no hospital. A familia depois tem que ir até o hospital para pegar o atestado de óbito para levar na funerária coisa que eu acho assim ... seria o serviço público que deveria se encarregar disso ou algum serviço ligado aí... a parte de epidemiologia pois antes você pedia eles forneciam; .... você mandava, às vezes, algum familiar ir até hospital a gente só preenchia;... na funerária eles faziam este serviço também....

\section{IC2}

A rotina de trabalho não atrapalha, em alguns aspectos até facilita, isto é quando a morte é hospitalar, se conhece o paciente, não se tem dificuldade para preencher o AO, com fácil acesso ao impresso

\section{DSC2}

Depois de tantos anos trabalhando ..eu não vejo dificuldade nenhuma. Uma coisa rápida, você faz em 5 minutos, você já tem tudo, já vem tudo pronto os dados você só preenche, assina. No hospital, é uma coisa mais dinâmica. O paciente vai a óbito, normalmente é o plantonista que verifica o óbito, aí a assistente social entra em contato com a gente eu vou até o hospital preencho, aí a funerária vai buscar o corpo lá e já sai com o atestado de óbito, então não tem envolvimento nem da familia. E aí você faz o preenchimento de acordo com que você acha... Dá para se definir como causa de morte principal e os fatores secundários colaboradores.

Para resolver uma questão social, burocrática eu tenho o hábito de já assinar este atestado... quanto mais rápido você resolver isto mais facilita as famílias. Olha, porque assim... a maioria dos pacientes que a gente vê são pacientes que a gente conhece. Na maioria das vezes o paciente falece ou de insuficiência respiratória aguda ou de insuficiência hepática ou caquexia, então, a causa básica de morte que se coloca... é parecida, tá?

Para nós aqui que estamos em um hospital grande, é fácil, se tem dúvida vai lá e pega o prontuário e lê.. é possivel, né? Os doentes que são do nosso ambulatório a gente também conhece, também não tem dificuldade. E hoje diminuiu bastante o número de atestados porque a internação caiu, assim.... de 100 porcento foi para 10.

Não dá para falar do sistema de saúde propriamente porque nós montamos um sistema particular, nosso ...e dessa forma ele não interfere. O que eu quero dizer é 
o seguinte: se este paciente precisa de um ultra-som, antes de pedir o ultra-som eu tô ligando para o radiologista para ele me encaixar o paciente e isso já foge do sistema atual de saúde, que é o tradicional ... Pega uma guia, autoriza, vai marcar, agenda, que demora tantos dias para vir o resultado, esse resultado vêem tenta se abrir uma consulta para mim e eu atendo, então isso seria uma rotina, né? $\mathrm{Na}$ verdade, com os nossos pacientes, a gente procura não fazer nem isso. A única parte burocrática é a seguinte: o paciente, ele tem que ser agendado pela primeira vez pela secretaria de saúde, porém, como a gente não tem fila de espera, tem agenda aberta, o paciente acaba vindo hoje pedindo à secretaria da saúde um atendimento, amanhã tá sendo atendido por mim.

..Eu sempre procuro pesquisar totalmente a causa da morte antes de preencher, certo? E quando eu sinto que não tenho condições de avaliar a condição de causa de morte eu sempre peço para fazer... o anátomo - patológico para pesquisa total ...... eu não assino mesmo se eu não tiver certeza. Eu acho que se você observar a legislação, cumprir com a sua parte não vejo problema, né? Então, pelo que eu sei até onde vai .. você é obrigado a dar $A O$, você constatou mas você não é obrigado a saber do que o sujeito morreu... Se houver algum óbito de causa violenta ou suspeita de violenta a gente que tem que realizar este exame necroscópico, terminado o exame, a gente de posse da requisição do delegado, que é o documento de identidade da vítima, então, a gente preenche $o$ atestado inclusive aqueles quadros de cima. Eu diria que facilita porque na verdade os atestados de óbito ficam aqui na sala de necropsia, então... terminado o trabalho da autópsia em si, a gente senta e preenche o atestado, tá lá.

\section{IC3}

A dificuldade é preencher sem saber a causa imediata do óbito

\section{DSC3}

Eu acho que a maior dificuldade no preenchimento é, realmente, saber o diagnóstico que levou, diretamente, a morte do doente. ..., geralmente, quando o paciente chega grave nunca tem certeza do que ele morreu, se é um tromboembolismo não tem os exames auxiliares para confirmar o diagnóstico, então você... Se você tá acompanhando paciente que tá estável, de repente ele tem uma dispnéia súbita e morre... por insuficiência respiratória, você põe como causa insuficiência respiratória aguda, então você dificilmente vai colocar um tromboembolismo pulmonar como diagnóstico. Houve uma parada cardiaca, num doente que é seu que tem um monte de doenças associadas, você, realmente, não sabe qual que é... Difícil chegar em um diagnóstico dele a não ser que seja uma coisa simples, uma pneumonia ou alguma outra coisa. 


\section{IC 4}

É indiferente pois além de ser um papel do médico, estou sempre presente quando ocorre e é um evento até certo ponto previsto pois os doentes são crônicos

\section{DSC4}

Se a gente pensar no atestado, só naquele pedacinho que é a parte médica, ele é uma conseqüencia do ato médico, você tem que cumprir um papel que é do médico... intransferivel. Tem o mesmo significado que o paciente que vem no consultório para uma consulta e pede um atestado. Porisso para mim é indiferente, é parte da própria medicina fazer isto, mesmo porque os próprios parentes, a gente vê que estão aflitos por essa situaçăo, para liberar o falecido e... onde eu trabalho tem uma grande quantidade de pacientes chegando no ambulatório e chamam para atender um caso de óbito para confirmação e depois a gente preenche....

Porque normalmente é assim: Se um paciente morre, o hospital te avisa e eu vou preencher aquele atestado. Seu paciente às vezes morre em um dia, dá para vocé ir no dia seguinte, não é uma coisa que é de urgência, que vocé precisa ir lá correndo, talvez, se fosse assim de urgência de ter que assinar naquele momento...

Além disso, ... na hora do óbito, geralmente a gente tá presente e aí a hora que vocé constata a gente mesmo pede para trazer o atestado e preenche e já assina, nunca tive grandes dificuldades em relação a isso.

E como sáo pacientes crónicos eu tenho uma noção de quais pacientes eu devo perder no próximo mês, no próximo trimestre, porque é um evento, até certo ponto, previsto, é lógico que acontece algumas exceções, mas habitualmente você prevê tudo isso e acaba não interferindo

Em relação ao cotidiano do trabalho médico, aqui buscando entender se a forma de trabalho interfere no preenchimento da DO, identificaram-se 4 eixos de representações : um deles é que a forma de organização do trabalho onde o médico está inserido dificulta muito o preenchimento da DO.

A dificuldade reside no grande volume de pacientes aliado às muitas dúvidas que, ainda, se têm quanto ao preenchimento. Em funçăo da pressão da própria demanda, o tempo é curto para preencher 0 atestado com tranqüilidade.

Este fato leva a erros, mas mesmo identificando o erro, muitas vezes, não se pode voltar atrás. 
Nos hospitais, os campos da DO de Identificaçáo, Residência, Ocorrencia, são completados, geralmente, no setor de internação ou pelo serviço social, Desta maneira, os médicos, também, se vêem submetidos à burocracia existente nestes locais.

A situação se complica mais quando a pessoa morre no domicílio ou poucos minutos depois de sua entrada no hospital, uma vez que o profissional não conhece o doente. Nenhum dos entrevistados relatou se colhe ou não informaçōes junto aos familiares, mas colocaram a prática de recorrerem ao prontuário quando esta pessoa, em algum momento, foi atendida no serviço em questão.

Interessante observar que mesmo de posse do prontuário, o médico coloca no campo VI, Parte I - doenças ou estado mórbido que causou diretamente a morte na linha a "morte sem assistència médica" e na Parte II -outras condiçōes significativas que contribuiram para a morte, e que năo entraram porém, na cadeia acima, completa com os dados encontrados no prontuário.

Este fato havia sido observado por ocasião da análise quantitativa. Muitas DO se apresentaram preenchidas na Parte I com "morte mal definida" ou "sem assistência médica" e na Parte II com patologias bem definidas. Naquele momento, a razão para tal fato não estava clara; de certa forma, só demonstrava o desconhecimento que os médicos apresentavam em relaçăo às regras para se identificar a causa básica de óbito, uma vez que pelas regras de seleção, neste caso, a causa básica que será considerada será a definida na Parte II. Desconhecimento esperado uma vez que estas regras são conhecidas pelos codificadores das DO.

Depreende-se deste fato que o médico cria códigos para demonstrar seu desconforto quanto a assinar um documento de uma pessoa que ele não acompanhou, como se fizesse uma resistência passiva à forma de organizaçăo do trabalho, como se ele fosse vítima do mesmo.

Uma grande dificuldade de assinar uma DO sem conhecer o doente passa pelo medo de estar atestando uma morte como natural, à medida que ela pode vir a ser "criminosa". Por isso, quando é "paciente caquético" "que chega até com sonda" ele "náo se preocupa tanto", pois ficou evidente que aquele pessoa 
apresentava um processo patológico e que, possivelmente, este vem a ser a causa da morte. A possibilidade que pessoas próximas, ou năo, a este indivíduo tenha praticado homicídio, eutanásia ou distanásia é uma possibilidade remota que sequer foi lembrada.

Aponta-se uma dificuldade em relação ao fluxo dos atestados de óbito. Atualmente, no município, os impressos das DO, que são controlados pela Secretaria Municipal de Higiene e Saúde, estăo disponiveis nos hospitais e IML. Portanto, quando a morte é domiciliar, há necessidade de um "pedido formal pro hospital" para que se possa conseguir o impresso, sendo esta dinàmica considerada "extremamente ruim" e "agressiva".

Como grande parte dos médicos entrevistados trabalha em serviços de urgência / emergência dos hospitais do municipio, aponta-se que neste tipo de trabalho o médico tem pouco tempo disponivel para o preenchimento do atestado de óbito. Mas aqui, como nos DSC da primeira questão, ficam evidentes os diferentes vínculos de trabalho. Ele atua nas enfermarias de diferentes hospitais, tanto acompanhando doentes de sua clínica privada quanto do serviço público de saúde. Alguns, também, mantém atividades em Unidades Básicas de Saúde. Desta maneira 0 atestado de óbito "torna-se um problema se eu tenho que me deslocar da onde eu tó para ir até o hospital para assinar...".

O outro eixo de representação se desloca para o extremo oposto ou seja, há um discurso que a rotina de trabalho facilita, de certa forma, o preenchimento do atestado de óbito. Mas é interessante observar que a rotina que os profissionais se referem é a relacionada aos doentes internados, pacientes conhecidos. Quando em ambulatório identifica-se a facilidade a medida que se estruturou uma organizaçăo paralela "nós montamos um sistema particular, nosso"; portanto, a facilidade encontrada depende em grande parte, ou da disponibilidade do médico em encontrar sistemas alternativos ou do vinculo estabelecido com este doente.

Identifica-se neste discurso o equivoco que existe em relaçăo ao conceito de causa básica de morte, uma vez que se coloca que "a maioria das vezes o paciente falece, ou de insuficiéncia respiratónia aguda ou de insuficiéncia 
hepática.... então a causa básica que se coloca .... é parecida". Na verdade estes são estados mórbidos que causaram diretamente a morte e não a causa básica.

Uma terceira forma de perceber se a rotina interfere no preenchimento da DO coloca a dificuldade mais uma vez; mas agora trazendo a incerteza da doença que levou diretamente ao óbito.

De fato este discurso não relaciona a dificuldade com a organização do trabalho médico, mas aponta um problema que o profissional enfrenta quando precisa identificar dentre as múltiplas patologias que o doente apresenta qual(is) teve ou tiveram maior significado na morte. Possivelmente este problema ficará cada vez maior, já que a percentagem de pessoas mais velhas vem aumentando na população, havendo uma tendência maior de apresentarem várias patologias concomitantes.

No quarto discurso identificado, os profissionais colocam que o preenchimento da DO faz parte do papel do médico e portanto está inserido em sua rotina de trabalho, sendo que esta nem facilita e nem dificulta. Discutem que os doentes são conhecidos $\theta$ com patologias crónicas e como $o$ ato de assinar o atestado não é uma urgência não atrapalharia as demais atividades em que estão envolvidos. Mas novamente os médicos estão se referindo a doentes hospitalizados e com um vínculo médico - paciente presente, como bem demonstra a frase a seguir. "na hora do bbito, geralmente a gente tá presente e ai a hora que voce constata, mesmo, pede para trazer o atestado e preenchen.

Chama atenção que o profissional coloca que a parte da DO na qual ele é responsável é "só naquele pedacinho que é a parte médica" , esquecendo-se que ao assinar esse documento, mesmo não tendo preenchido os demais campos, ele responde por todas as informaçōes ali contidas. 
Pergunta 4- O atestado de óbito é um documento legal, não é? Isto traz algumas conseqüências. Esta é uma coisa que preocupa você, ou nâo? Fale um pouco sobre isto.

\section{Idéias Centrais}

1-Preocupa muito, desde fazer errado, ser mal interpretado e ter implicações legais como por exemplo ser chamado para esclarecer, além disso sabe que gera direitos (seguro), mas também porque tem medo de assinar qualquer coisa.

2- Não preocupa, porque sabe preencher, os doentes são conhecidos bem como suas respectivas patologias de base e só escreve quando tem certeza do diagnóstico. Assim o AO é uma segurança para o médico.

\section{IC 1}

Preocupa muito, desde fazer errado, ser mal interpretado e ter implicaçōes legais como por exemplo ser chamado para esclarecer, além disso sabe que gera direitos (seguro), mas também porque tem medo de assinar qualquer coisa.

\section{DSC 1}

Eu tenho medo de implicação legal, todo mundo tem, não sou só eu. Eu sei que por lei deveria existir um serviço de verificação de óbito em qualquer município, do meu país. Mas, ele não existe. Então, o que fizeram? Alguém determinou eu não sei, se foi diário oficial,... Não sei se foi CRM que o médico que tiver na porta de um hospital vai fazer a verificação de obbito. Estas verificaçōes de óbito são um acordo de cavalheiros que a diretoria fez com a prefeitura e com o IML porque senão todos teriam que estar indo para o IML. Quando eu preencho esse atestado eu coloco que estou fazendo verificação de óbito, eu não coloco que eu sou o médico, sou substituto nada, no quadrinho eu ponho lá... que eu sou do SVO porque se alguém me questionar eu falo que eu vi uma paciente que chegou na porta do hospital, examinei... não tinha lesão nenhuma externa... e eu coloquei como sendo morte de causa desconhecida, ou morte em trânsito, pronto... eu náo sei de nada... E uma forma de fugir do medo.

Eu acho que em termos de um hospital - escola seria muito importante que tivesse o serviço de verificação de óbito. E necropsia é aquela história, ou paga ou a familia vai à delegacia e faz um boletim de ocorréncia exigindo, ou é uma morte violenta que a própria polícia se encarrega de fazer, às vezes náo se encaixa em nenhum dos três casos e sai o atestado ...mas é uma falha que não é minha, é uma falha do sistema que está aí. Que é uma coisa que eu acho que está errada, nós não conhecemos estes pacientes... 
Porisso na faculdade é uma coisa que me angustia de assinar um...(atestado) Porque muitas vezes o serviço trata do paciente com vários profissionais e as vezes vocé não tem condiçōes de saber a patologia e acaba não tendo necropsia. Pois aquilo é um documento vocé vai assinar, vai por seu CRM. Bom, eu tenho medo de assinar qualquer coisa. Porque hoje em dia o que a gente vé aí de processo deste tipo de coisa, voce tem que estar mais atento para isto porque qualquer detalhe ou qualquer coisa que se coloque em termos de diagnóstico pode ser levado em termos legais para outras interpretaçöes. Eu não sei se pode acontecer no caso de um atestado, mas eu tenho medo... De preencher errado, ter que depor, ter que ir num tribunal. Preocupa, às vezes eu não sei direito como escrever e vocé pode ser chamado para esclarecer.

Eu já fui para a delegacia, várias vezes, por problema legal.

Também eu tenho uma certa preocupação, com a causa mortis, o mecanismo direto do óbito; isto é mais complicado, muitas vezes vocé não tem uma noção exata do que aconteceu de fato. Foi a sepsis em si? Foi a sepsis que levou a um desequilibrio hidroeletrolítico metabólico que ocasionou aquele óbito? Foi a sepsis que levou algum transtorno de hemostasia que acabou resultando no óbito? Como um documento legal .... eu tento colocar o máximo possível de causas indiretas da morte para que tenha possibilidade de ter morrido daquilo mesmo que a gente colocou. Mas preocupa, mesmo estando todos os nossos atestados relacionados a um exame necroscópico, onde você tem um laudo e vocé tem a documentação muitas vezes fotográfica.

Fica uma preocupação no sentido de você deixar as coisas bem mais claras e de uma forma incontestável, até para que isto não venha resultar futuramente não só para vocé mas para a família também, pois para a familia é muito importante o seguro de vida quando a pessoa morreu, né? Eu sei que este $A O$ em algumas circunstâncias ele gera direitos em relação a processos sucessórios, de heranças etc..... E me preocupa, também, eu conseguir informar, bem, do ponto de vista daqueles que vão fazer os estudos e os levantamentos estatísticos.

\section{$1 \mathrm{C2}$}

Não preocupa, porque sabe preencher, os doentes são conhecidos bem como suas respectivas patologias de base e só escreve quando tem certeza do diagnóstico. Assim o AO é uma segurança para o médico.

\section{DSC 2}

Eu não tenho preocupação, a gente sabe da importáncia de escrever bem, ou pelo menos contar do que morrem as pessoas e eu tenho o respaldo do ponto de vista de notificação do que aconteceu com doente na ficha de atendimento.

Além disso, é uma obrigação médico-legal. Antigamente, não tinha essas coisas de ética... de preencher. Não, eu acho que sempre tratamos de fazer o melhor, os atestados. Na verdade eu só relatei o que aconteceu, a gente só escreve aquelas coisas que a gente tem certeza, baseado sempre em dados, fatos reais, a gente 
náo pode achar nada, porque a patologia de base, esta vocé teve uma oportunidade de ficar um tempo maior para poder trabalhá-la, geralmente são pacientes crônicos, sou eu que acompanho, sou eu que tenho a história dele, sou eu que vejo as complicações dele; faz parte do meu vínculo com esse paciente. Quando é no meu plantão, na urgência e chega obito, às vezes um infartado, a maioria deles, tem médico próprio, então a gente constata o óbito, entra em contato com o cardiologista... Na verdade o que eu procuro fazer é com que os dados do atestado tem que ser verídicos, tem que ser precisos. A veracidade é fácil da gente fazer, se a gente não encontrar a causa não declara; quanto a precisão aí às vezes nós não temos recursos diagnósticos. Mas como eu sou cirurgião eu tenho todos os fundamentos para preencher, pelo menos, o mais próximo possivel do que aconteceu com o paciente.

Não vejo qualquer dificuldade no preenchimento de um (atestado) porque eu procuro fazer o melhor que eu posso... quando ela morre eu sinto pela morte dela, mas eu, inclusive, procuro colocar o máximo de informações possiveis para que se possa estudar a causa de óbito para chegar a uma conclusão final. Então eu acho que o bom preenchimento do atestado é uma segurança para o médico e não um risco. Desde que você faça as coisas da maneira correta.

O AO passa a ser uma arma contra o médico, quando este médico náo sabe manipular o próprio atestado, faz diagnóstico errado, trata errado e trata a família de uma forma não usual. Assim, o preenchimento do Atestado, no meu ponto de vista não é mais um bicho de sete cabeças porque eu sei preencher, é raro as coisas que eu tenho dúvida.

A Declaração de óbito enquanto um documento legal é reconhecido por todos, mas o sentimento que este fato mobiliza apresenta 2 formas diferentes de representações: em uma, o discurso dos médicos apresenta-se com grande preocupação.

O cerne desta preocupação refere-se ao medo das implicaçōes legais que podem advir de um preenchimento inadequado. Por outro lado esse medo parece ser sem fundamento uma vez que "eu náo sei se pode acontecer (processo) no caso de um atestado". Como uma das formas de se driblar esse sentimento volta a se colocar a dificuldade de se preencher um atestado de óbito sem ter um serviço de verificação de óbito (SVO) constituido pelo poder municipal. Parece, em determinados momentos, que este serviço resolveria todos os problemas dos médicos em relação à $\mathrm{DO}$.

$\mathrm{O}$ fato de assinalar no item 52 do campo $\mathrm{VII}$ - O médico que assina atendeu ao falecido?, que consta da DO, como SVO, sem que o município 
contasse com este serviço estruturado era, no mínimo, um encontro inusitado, quando das avaliaçōes dessas declaraçőes na primeira fase deste trabalho. Mas a lógica só se torna compreensivel neste momento, com a frase: "é uma forma de fugir do medo".

Assim, assinalar este item sendo na verdade médico $\underline{\text { Substituto ou Qutros }}$ demonstra a dificuldade de se lidar com esta situação, como se pode observar nesta fala: "porque se alguém me questionar eu falo que vi uma paciente que chegou na porta do hospital, examinei... não tinha lesão...externa e eu coloquei como sendo morte de causa desconhecida... eu nåo sei de nada".

Verifica-se, ainda, que uma grande inquietaçăo se refere, principalmente, ao seguro de vida e demais benefícios sociais que a familia da pessoa que morreu teria direito, a partir da existéncia da DO. Mas esta existência por si só não garante o recobimento destes benefícios, o seu preenchimento deve estar de acordo com as cláusulas contidas no contrato realizado. Percebe-se que os médicos ficam, de certa forma, pressionados, talvez pela familia ou pela própria seguradora, em "deixar as coisas bem claras e de uma forma incontestável" na DO.

Um dos profissionais colocou que foi ameaçado por um agente de seguro em função de uma DO de uma pessoa que veio a morrer subitamente no domicilio. O agente chegou a lhe colocar textualmente : "voce năo sabe preencher atestado de óbito.... agora vocé está ferrado *

Estes eventos reforçam, na visăo dos médicos, a necessidade de se estruturar um serviço de verificaçảo de óbitos.

Neste discurso identifica-se a faculdade de medicina como sendo o local de eleição para o melhor conhecimento dessas mortes através das necropsias. Essas, também, viriam resolver um problema relacionado ao modelo de assistência à saúde organizado por especialidades, onde o doente é visto de forma fragmentada, por diferentes médicos de diversos serviços e "às vezes você não tem condição de saber a patologia" que levou a morte.

O outro eixo de representação coloca o discurso no lado oposto, ou seja, neste os médicos dizem que náo se preocupam com o fato da DO ser um 
documento legal. Apontam que saber preencher a DO é um ponto importante para esta despreocupação e encaram o atestado de óbito como sendo uma "...segurança para o médico e náo um risco". Assumem que pode se transformar em uma arma contra o médico, quando ele "não sabe manipular o próprio atestado, faz o diagnóstico errado, trata errado e também trata a família de uma forma não usual." Importante ressaltar que neste grupo a maior parte dos médicos é formada por cirurgióes elou legistas, que, na grande maioria das vezes, realizam necropsias para emitirem as DO.

\title{
Pergunta 5 - A seu ver para que serve uma DO?
}

\author{
Idéias Centrais (IC)
}

1- A primeira finalidade é registrar a morte e esclarecer as suas causas, tanto legais como cientificas, para fins de sepultamento, herança, seguro, previdência e isentar o Estado do pagamento de taxas de aposentadoria, pensōes etc..

2- A segunda finalidade é relacionada aos estudos estatísticos para elaborar planos de saúde, aprimorar a organização de serviços de saúde e dos médicos, avaliar as doenças epidêmicas ou mais prevalentes, orientar o currículo de escolas médicas e também ver as falhas da saúde pública.

IC1

A primeira finalidade é registrar a morte e esclarecer as suas causas, tanto legais como cientificas, para fins de sepultamento, herança, seguro, previdência $\theta$ isentar o Estado do pagamento de taxas de aposentadoria, pensões etc..

\section{DSC1}

A DO tem vánios aspectos, o primeiro é o aspecto legal, é o instrumento pelo qual - cartório de registro das pessoas naturais vai dar o fim legal da vida de um indivíduo, ele deixa de ser cidadão do ponto de vista civil. Nasceu, viveu e morreu e foi enterrado em tal lugar para se ter o controle de quem tá morto. Ela serve para elucidar o diagnóstico que a pessoa tinha, registrar realmente a causa da morte do doente. Se ela morreu de uma doença ou se foi acidente. No caso de mortes violentas, até para esclarecer a causa legal e muitas vezes científica da morte.

Uma vez que o individuo morreu, teoricamente, ele pertence ao Estado, e o Estado precisa saber, para poder organizar toda a questáo legal da existéncia de 
uma pessoa. Isso a gente vê aí, uma série de problemas: individuo que morreu e tá vivo e indivíduos que têm atestado de óbito para ele receber beneficios de previdência, até questóes trabalhistas, e questŏes jurídicas. Também acho que é uma padronização do ponto de vista social pois as pessoas têm que ter uma forma dirigida de como proceder no enterro de uma pessoa, as autoridades (devem) controlar isso se não vai virar uma terra de ninguém. Para o governo é vantajoso dado o atestado de óbito, ele fica isento das taxas.

Então, o papel é a parte burocrática para abrir outras portas para a familia do paciente: seguro, atestados, ressarcimento de empresas, de previdéncia, como um documento até para meios legais, para divisão de herança. Mas não é ela (DO) que é a prova que morreu pois quem prova é lá na hora que vocé coloca, lá na prescrição que o paciente estava assim..assado... E evoluiu a óbito a tal hora, né?

Assim, eu penso que ela tem, às vezes, uma finalidade monetánia. Porque, muitas pessoas fazem seguro, dependendo do que eu coloco de diagnóstico no atestado eu vou prejudicar a família.

IC2

Uma das finalidade é relacionada aos estudos estatísticos para elaborar planos de saúde, aprimorar a organização de serviços de saúde e dos médicos, avaliar as doenças epidèmicas ou mais prevalentes, orientar o curriculo de escolas médicas e também ver as falhas da saúde pública.

\section{DSC2}

Uma das finalidades técnicas do atestado, à medida que vocé aprimora o preenchimento do $A O$, vocé está prestando uma contribuição para a organização dos senviços de saúde em cima da mortalidade prevalente. Já que também consta a morbidade, fatores ligados a eventos fisiopatológicos que desencadearam a morte, a causa básica. Como estratégia de planejamento da saúde por parte do governo. A declaração de óbito serve principalmente do ponto de vista da estatistica de doenças, de medicina sanitária, saúde pública e preventiva. Permite que as autoridades saibam de que as pessoas estão morrendo no seu território, estado, pais; e baseado nestes dados podem tomar açoes totalmente corretivas que visem impedir ou diminuir este tipo de causa mortis mais prevalentes; para você poder programar a sua renda. Ele pode orientar como nós devemos proceder em determinados casos. Mostrando para nós um caminho melhor para que não se vá a óbito. Além disso, possibilita ver as falhas da própria saúde pública. Não sei até que ponto que o atestado de óbito pode ajudar mas, pelo fato de estar morrendo mais gente por uma causa, isto traz alguma complicação em termos de dinheiro do exterior que possa tá vindo, como financiamento de tratamento no caso da Aids, no caso de câncer, e tudo o mais.... Presta, ainda, para fazer 
levantamento do que é mais comum, se é violento ou não, da incidéncia de óbito em gestante, a idade e no caso de doenças que podem gerar processo de epidemias.

Então, consequentemente a classe médica interessada e a comunidade vai saber, aqui nessa região a causa morte é isso... e o médico realmente, poderia avaliar a qualidade de seu serviço, daquilo que faz como profissional;

quantos infartos morreram no ano de 2002, quantas causas indeterminadas ou em tránsito, ou mal definidas foram emitidas no ano de 2002 para a gente se policiar. Portanto, com o preenchimento correto vocé dá dados epidemiológicos corretos pois é como se fosse uma certidão de nascimento, senão você subestima tantos dados de nascimento como de morte também ..

Além disso, a DO também deveria servir para as escolas médicas como orientadoras de seu currículo, da formação que o seu aluno deva ter.

Das finalidades das DO, emergiram dois discursos, que eventualmente se complementam, mas que foram separados em virtude de suas especificidades; um se refere, basicamente, aos aspectos legais e individuais que envolvem a DO e o outro aborda a abrangência coletiva, sua finalidade estatística.

No primeiro eixo de representaçăo verifica-se que os profissionais assemelham a DO com a Certidão de Nascimento : "...toda pessoa tem um registro, ....consta desse registro que ele nasceu em tal lugar, e o atestado de óbito é .... um documento para fechar este registro".

Discutem a importância deste instrumento para padronizar o comportamento da sociedade quanto às questóes de sepultamento, e do papel do Estado como normalizador, garantindo a organização da "questão legal da existência de uma pessoa...", para não ter mais necessidade de pagar os benefícios que Ihe eram devidos em vida, tais como : salário, aposentadoria, pensão etc.

Além de discutirem a importância da DO para desencadeamento de heranças e testamentos, volta o ponto do seguro como uma das finalidade importantes deste documento. Alguns médicos identificaram, somente, essa finalidade da DO, colocando que "...só através desse papelzinho que ela (familia) abre várias outras portas, seguro..." 
Emerge aqui uma questão muito interessante, onde este documento não é reconhecido como prova cabal da morte, uma vez que se considera que “...quem prova é lá.. na hora que você coloca, lá na prescrição que o paciente.... evoluiu para óbito a tal hora..."

$\mathrm{Na}$ segunda representação o discurso é claro quanto ao papel desempenhado pelo governo, seja ele federal, estadual ou municipal, na capacidade de intervenção, utilizando as estatísticas provenientes das DO. Esta intervenção se dá no âmbito da diminuição da "... causa mortis mais prevalente..." e também para "...programar sua "renda", para onde vai agir mais ou não..." . Estas falas demonstram não se saber bem, como isto ocorre, mas há uma percepção que é possivel se realizar este tipo de controle.

Estas estatísticas estão centradas basicamente nas causas de morte e algumas características das pessoas, tais como: idade e ser gestante.

Os médicos levantam, também, a importância desses dados para a comunidade, para si próprios, à medida que podem avaliar a qualidade do seu trabalho e também como norteadores na construção dos currículos nas escolas médicas.

\section{IV.2.1. Análise dos discursos}

As hipóteses que nortearam este trabalho foram as que o preenchimento das declarações de óbito sofrem influência : a) da organização do trabalho em saúde; b) do conhecimento que o médico tem a respeito deste instrumento, tanto do ponto de vista de suas finalidades como da capacitação formal que o tornasse apto para esta ação; c) do medo que o profissional tem uma vez que a DO tem um caráter legal; e d) da dificuldade que o médico apresenta para lidar com a morte.

Verificaram-se através dos DSC que essas hipóteses estão interrelacionadas. Mas, por uma questão didática, elas foram separadas e trabalhadas como temas. 
IV.2.1.a. Tema I - Organização do trabalho médico

Apesar de existir uma pergunta específica em relação a influência do trabalho no preenchimento da DO, essa questão foi tratada, também, nos demais discursos. Para analisar este tema partiu - se de dois pontos que também se entrelaçam, quais sejam : 1) o modelo assistencial e 2) a prática médica enquanto uma profissão.

\section{1) Modelo Assistencial}

Desde a primeira pergunta os discursos demonstraram a relação do preenchimento da DO com o modelo assistencial vigente no qual o médico está inserido, pois ao serem questionados sobre os sentimentos que percebem quando preenchem um atestado de óbito, já colocam que "depende do local onde estou : na UTI ou no PS".

Pode-se conceituar modelo assistencial como sendo a forma como os serviços de saúde de diferentes complexidades tecnológicas se articulam e se organizam internamente, em um determinado território.

No Brasil o modelo assistencial predominante ainda é o médicoassistencial privatista, centrado na demanda espontânea. Ao contrário do que se poderia supor, esse não é exclusivo do setor privado, "seja da medicina liberal, das cooperativas médicas, da medicina de grupo, do seguro saúde". Esse modelo também é o hegemônico no setor público. As Unidades Básicas de Saúde (UBS) e os hospitais públicos trabalham com a lógica da demanda, são fundamentalmente curativos, centrados na doença e não no doente ${ }^{(13)}$. Organizam o serviço não levando em conta as necessidades de saúde das populações pelas quais são responsáveis e sim pela procura de determinado tipo de atendimento. Portanto, estas instituições não se comprometem com o impacto que possam ter na saúde da população assistida ${ }^{(20)}$. Geralmente este tipo de organização está centrado no médico, dele depende o atendimento de um grande número de pessoas com tempo insuficiente para se estabelecer um vínculo adequado. Assim, "a rotina de trabalho dificulta e muito ... o preenchimento" e quando isto ocorre no serviço de urgência "é mais difícil... a gente toma conta de três ao mesmo tempo..." 
O modelo médico assistencial privatista também pressupõe uma prática utilizando o hospital como a "forma mais apropriada de espaço terapêutico", pois congrega em seu interior todo o arsenal de equipamentos diagnósticos e terapêuticos necessários para atender as pessoas. Interessante verificar que quando a morte é hospitalar, principalmente se o doente ficou internado "por mais de 4 dias..", mesmo sendo do Sistema Único de Saúde, é possível se estabelecer um vínculo com o doente. Nesse caso o médico aponta um maior envolvimento chegando a "sentir" ao preencher o $\mathrm{AO}$.

Atualmente, este espaço hospitalar se tornou excessivamente caro, devendo, cada vez mais, ficar reservado aos doentes com patologias graves e urgentes. Verifica-se então, uma tendência de se acompanhar o doente no domicílio, quando o hospital tem pouco ou nada mais a oferecer para a manutenção da vida daquela pessoa.

Com esse fato surge uma dificuldade em se conseguir os impressos das Declarações de Óbito, já que essas são controladas e distribuídas pela Secretaria Municipal de Saúde. Esses instrumentos estão disponiveis nos hospitais e no Instituto Médico Legal, uma vez que até bem pouco tempo atrás $90 \%$, ou mais, dos óbitos ocorriam nas unidades de internação. O município, ainda, não tem mecanismo de distribuição de DO para as mortes domiciliares. Há necessidade que o médico faça um pedido formal, por escrito, ao hospital. Parece que a Secretaria Municipal de Higiene e Saúde não se deu conta do aumento da freqüência dos óbitos domiciliares, a tempo de viabilizar uma proposta mais compativel com esta nova realidade.

Vários municípios brasileiros, incluindo o de Marilia, fazem hoje um movimento para alteração desta forma de organização por um modelo assistencial de base epidemiológica, que por sua vez vem ao encontro dos princípios do SUS, objetivando estabelecer uma rede de serviços articulada, hierarquizada e regionalizada em função das características epidemiológicas de cada área de abrangência. 
Mas esta discussão de modelo se impõe à medida que, nem no modelo médico-assistencial privatista e nem no de base epidemiológica, no qual as informaçōes de mortalidade são fundamentais, a DO é explicitamente colocada como fazendo parte do trabalho desta organização de saúde.

Como estruturar uma rede de serviços que é responsável por uma determinada área de abrangência, cuja equipe de saúde organiza o cuidado levando em conta as necessidades desta populaçăo, necessidades estas analisadas de acordo com as características epidemiológicas do território, sem que esta mesma equipe garanta à família de alguém que morre o documento que tanto desencadeia os aspectos legais da morte como também possibilita uma análise da qualidade de sua intervenção, entre outras coisas?

O preenchimento da DO mostra a cisão entre a prática liberal e a pública. A primeira é aqui sinônimo daquela praticada nos consultórios particulares, que na maioria das vezes de particular tem pouca coisa, uma vez que a grande clientela tem convênios médicos que restringem os meios diagnósticos em número e em tipos de procedimentos. Esta cisão pode ser verificada à medida que nos discursos dos médicos aparece com muita clareza a facilidade de se preencher este instrumento quando "... são pacientes que a gente conhece... e geralmente na hora do óbito a gente tá presente..." e a dificuldade de se preencher DO de doentes "que náo se conhece". Mas o que se pôde observar nas análises de prontuário realizadas na fase 1, esta pessoa "que náo se conhece" foi atendida no PS ou nos ambulatórios, tanto da rede básica como nos de especialidades da faculdade de medicina, em diversos momentos durante o periodo que antecedeu a morte. Portanto este "desconhecimento" é gerado, em alguma parte, pela própria organização do trabalho das instituiçōes que prestam assistência médica.

Interessante identificar que há uma diferença quando se atendem pessoas que morreram no hospital universitário em relaçăo às do pronto socorro do hospital filantrópico. No primeiro o plantonista recorre ao prontuário, quando o faz, para preencher a DO; já no "filantrópico", ajjo serviço de urgência é terceirizado, o médico liga para o colega que atendia o doente em questão, à medida que a familia relatava que o doente estava em tratamento. 
2) Prática Médica, a profissão.

Entende-se a DO como sendo um elemento da prática médica e a forma de realizá-la e/ou de entendê-la passa pelo entendimento da própria prática exercida pelos profissionais médicos.

O exercicio da medicina e profissões afins somente foi regulamentado em 1932, por decreto do Governo Provisório da República, que gerou inúmeras dificuldades para ser aplicado no Estado, frente aos direitos adquiridos dos "falsos médicos" (112).

A profissão médica pode ser assim chamada pois apresenta: exclusividade de realizar atividades relacionadas a uma determinada área de conhecimento que é estruturada a partir de um processo de formaçăo prolongado; a ela corresponde um padrão de comportamento que tem por base um sistema de valores e em sua essência apresenta um "ideal de autonomia"(26).

O Modelo assistencial médico privatista, discutido anteriormente, é centrado no médico que é legitimado socialmente como o "detentor do poder de curar" $(20,62)$. Este fato traz para a prática médica algumas caracteristicas peculiares, ou seja, o médico tem o monopólio do saber, a prática da cura e, diferente de todos os demais profissionais da equipe, tem o "controle final da qualidade dessa prática" e é com muita dificuldade que admite um controle de qualidade externo.

Segundo Gramsci "A categoria dos médicos, em sentido lato, isto é, de todos aqueles que lutam ou parecem lutar contra morte $\mathrm{e}$ as doenças.... dada a continuidade histórica e sua qualificaçāo ... consideram a si mesmos como autônomos e independentes do grupo social dominante" (37).

Levando em conta estas considerações a respeito da categoria, para se garantir a alteração de Modelo Assistencial, há que se modificar toda uma forma de trabalhar. As equipes de saúde têm a lógica do Modelo médico-assistencial privatista impregnada como uma segunda pele, é com esta lógica que os profissionais de saúde são formados e é esta a forma de receber serviço de saúde que a população, apesar de insatisfeita, conhece e muitas vezes reivindica. 
O poder e prestigio que os médicos, hoje menor, mas que ainda, apresentam não ocorreram ao acaso. Eles foram alcançados quando os fundamentos teóricos, que embasam a profissão que se estrutura na especialização técnico-científica, foram comprovados como capazes de equacionar e resolver problemas técnicos de interesse social e, principalmente, pela capacidade de organizar-se em torno de interesses corporativos ${ }^{(112)}$.

O atestado de óbito foi um destes instrumentos de "interesse corporativo" pois é uma antiga reivindicação da categoria médica, como uma forma de coibir atividades "médicas" de pessoas (curandeiros, práticos em homeopatia) que não haviam passado por um processo formal de ensino para exercerem tal prática ${ }^{(83)}$, mas ao mesmo tempo resistiram ao fato da obrigatoriedade de se colocar a causa de morte, invocando o sigilo médico.

A valorização da profissão médica enquanto um projeto de ascensão social, ter o reconhecimento da sociedade, garantir o poder e o prestígio que historicamente esta profissão confere aos seus agentes fica um tanto abalada à medida que ocorre a morte de uma pessoa que, na maioria das vezes, estava sob cuidados médicos, e haverá a necessidade de se preencher uma DO, que é a prova concreta desta morte. Como garantir a autoridade, a ascensão pretendida se os doentes sob seus cuidados morrem? Este fato póde ser observado através da fala de um dos médicos, descrito abaixo.

Um dos entrevistados colocou que sua familia era de uma cidade vizinha de Marilia e que, enquanto residente de clínica médica na faculdade de medicina, assinou muitos atestados de óbito de pessoas residentes em sua cidade natal. Um determinado dia seu pai the chamou, preocupado, porque a pessoa que trabalhava no cemitério do município o havia procurado dizendo que as pessoas que seu filho cuidava morriam e que isto não seria bom para ele. Ou seja comprometia o seu prestigio.

Cecilio discute que é necessário recolocar "o papel do médico" no serviço de saúde e propōe para isto normalizar o trabalho do médico segundo a "lógica da corporaçāo" e a "lógica da organizaçāo". A primeira leva em conta o conhecimento médico necessário e suficiente que possibilite a intervenção com 
eficácia. A segunda é o cumprimento, pelo profissional, das normas e rotinas que regem a organização, incluídos aqui todo e qualquer preenchimento de formulários, prontuários ${ }^{(20)}$.

Os atestados de óbito não foram explicitamente citados pelo autor e é interessante observar que, nos trabalhos consultados sobre o tema, a DO como instrumento que faz parte do trabalho médico não é mencionada. Muitas vezes coloca-se a importância das informaçōes de mortalidade para embasar as intervençōes, mas parece que esta informaçāo surge do nada ou é magicamente construida pela Secretaria de Saúde, "...permite que as autoridades saibam do que as pessoas estáo morrendo em seu território....baseado nestes dados podem tomar ações totalmente corretivas..."

Schraiber em seu livro "O médico e seu trabalho" aponta que os profissionais que entrevistou "testemunharam a criaçăo da medicina tecnológica", que foi por eles incorporada ao longo de suas vidas profissionais. Mas que ao mesmo tempo preservaram elementos norteadores que thes deram identidade no inicio de suas carreiras enquanto profissionais liberais. Um desses pontos fundamentais foi a concepçăo de autonomia, pois uma vez esta garantida estaria preservada a essência da identidade médica (98).

Tanto na fase de análise quantitativa como através dos discursos presentes neste trabalho pôde-se observar este elemento - autonomia - como sendo um diferencial no preenchimento da DO. No estudo quantitativo, à medida que o médico que assinava o AO era o mesmo que havia assistido o doente, fato que fica bem evidente nas DO dos individuos que morreram com patologias presumiveis de AIDS, praticamente $100 \%$ delas estavam corretas.

Nos discursos, quando o doente vinha sendo acompanhado e havia relaçáo médico-paciente constituída, os profissionais apresentavam sentimentos de pesar mas não tinham dificuldades de preencher as DO, alegando que "a maioria dos pacientes a gente conhece" ou "na hora do óbito a gente tá presente". E mesmo atuando em um serviço público, cujos pacientes são considerados do Sistema Único de Saúde, o profissional cria um sistema paralelo com características de seu consultório particular. Esta forma de organizar a produção de serviços 
(consultório particular) seria aquela "capaz de corporificar as condiçōes necessárias e adequadas para o exercício autỏnomo" ${ }^{(\bullet)}$.

"O que eu quero dizer é o seguinte: se este paciente precisa de um ultrasom, antes de pedir o ultra-som eu tó ligando para o radiologista para ele me encaixar o paciente..." Esta fala deixa claro que o médico se articula com os serviços complementares utilizando a relação interpessoal, o seu prestígio e o seu conhecimento. Esta forma de atuar resulta em "manutençăo do controle da prática", que se funda na autonomia $\theta$ independência como caracteristicas tradicionais dos médicos. Para estes profissionais, apesar dos doentes estarem vinculados ao SUS, estabelece-se uma boa relaçăo médico-paciente onde a dificuldade em se preencher o DO é menor.

Um outro aspecto que chamou atenção foi a necessidade dos profissionais colocarem, em um primeiro momento, a DO no contexto da prática. Assim, antes de responder a pergunta propriamente dita, ele dava um depoimento de como estabeleceu, ou não, a relação com as pessoas para quem ele forneceu ou fornecerá a DO. Geralmente, este preâmbulo era para explicar que "o médico tem que fazer parte da receita, da mesma forma que voce prescreve dipirona... voce tem que prescrever o (médico) junto, senáo o tratamento não funciona...Portanto a relação médico-paciente tem que ser a mais real e transparente possivel; entáo, dentro deste contexto a DO também é transparente."

Schraiber apontou esta representação em seu estudo onde os médicos afirmavarn que "boa parte do resultado satisfatório reside na confiança que tem o paciente no médico" e completa, que esta confiança está relacionada à segurança que o próprio médico tem na conduta adotada ${ }^{(90,26)}$.

Desta forma, contextualizar a DO a partir da característica de uma relaçăo médico-paciente "transparente" pode ser uma estratégia para se proteger do sentimento que a morte gera, pois, em última instáncia, se o doente morre significa que o próprio médico "morreu" enquanto "terapéutica". De alguma forma - sentimento de impotência que o preenchimento do atestado gera pode ser explicado por esta crença que ele (médico) personaliza o tratamento instituído ao doente. 
Outro fator da prática médica que pode influenciar no preenchimento da DO está relacionado com as caracteristicas que o objeto do trabalho médico se estrutura dentro do cotidiano de suas atividades. Teoricamente o objeto é um sujeito social, que apresenta uma patologia.

A prática médica dentro do Modelo assistencial privatista faz com que os doentes que apresentam particularidades sociais concretas, sejam vistos como sendo "socialmente iguais". Este processo ocorre quando não se enxerga uma pessoa com uma determinada doença, mas uma doença em um corpo, ou seja aquele doente se transformou em um "corpo patológico". Para que esta transformação se dê o médico utiliza os recursos universais, tais como: a anamnese, exame-físico, exames complementares $\theta$ até a DO, que escondidos na aplicação da técnica uniformizam as pessoas. A DO utilizada enquanto uma técnica pode ser preenchida maquinalmente e sofrer uma desvalorização, uma vez que ela só ganha significado do ponto de vista individual, à medida que ela desvenda aquele sujeito que morreu e do ponto de vista coletivo, quando revela a realidade social.

Mas estes procedimentos técnicos ( anamnese, DO etc..), em conjunto com o ato de realizar diagnósticos e instituir tratamentos, fazem o vínculo da técnica com a ciência, uma vez que toda atividade técnica tem uma teoria cientifica que a sustenta. Nesta relaçăo, da técnica com a ciència, é que o trabalho médico se caracteriza como sendo eminentemente intelectual, apesar disso, o ato médico traz em seu cerne atividades manuais que são imprescindiveis ${ }^{(99)}$. Mas historicamente, particularmente na prática médica, a atividade manual tem menor valor do que as ações de cunho intelectual consideradas cientificas. Pode ser que este fato explique a aversão que alguns médicos têm em escrever, pois se sentiriam burocratas quando se faz necessário o preenchimento do prontuário ou do atestado de óbito mostrando a rejeição por atividades pouco cientificas intelectuais.

Ao se analisarem os prontuários para a realização da fase I deste trabalho, deparou-se com uma grande pobreza de informaçōes, principalmente quando eram fichas de atendimento de doentes atendidos nos hospitais "filantrópicos". Os 
prontuários do hospital universitário apresentavam informaçőes mais completas, possivelmente por serem elaborados pelos estudantes em processo de aprendizagem. Mas, quando se comparavam as fichas da clínica médica com as da cirúrgica, estas últimas deixavam a desejar, pode ser que não "escrever, não preencher os prontuários adequadamente" seja uma forma de esconder o fato que na clínica cirúrgica é onde a atividade manual é preponderante em relação às áreas clinicas.

Tema II - Conhecimento do instrumento e de suas finalidades

Nesta hipótese os médicos se movem através dos discursos, apontando ora para a capacitação no ensino de graduação, ora nos cursos de especialização $\theta$ residência e ainda na própria atividade cotidiana. Assim o que está em jogo é verificar como a educação médica está estruturada e como se insere o ensino da DO.

Para efeito de análise associou-se a pergunta em relação ao aprendizado do preenchimento da DO com a se suas finalidades.

A grande crítica que se fez ao ensino do preenchimento dos atestados de óbito é que este foi desvinculado da prática. Além disso, foi ministrado pela medicina preventiva e ou medicina legal, disciplinas, eminentemente, teóricas.

É necessário investigar o que significa ser " desvinculado da prática", ou seja a educação médica como está estruturada hoje possibilita que os estudantes vivenciem ( o vinculem à pratica) o preenchimento da DO?

O estudante para se transformar em um médico deve se submeter a uma série de atividades encadeadas e ao mesmo tempo estabelecer vínculos com as pessoas que participam do seu processo de formação(30).

A educaçāo ( médica) e a prática médica estão de certa forma atreladas, uma vez que quando uma se modifica impỏe mudanças à outra. Entretanto, a educação médica mantém uma relativa autonomia à medida que se configura 
como um "campo de práticas específicas educacionais" ${ }^{(98)}$. Isto significa que a instituição educacional se dá o direito de realizar uma "prática médica" um pouco diferente da existente nos serviços de saúde, uma vez que aquela é uma práticaensino, ou seja é uma prática cujo objetivo é o ensino e é neste espaço educativo que se elabora uma concepção médica. Mas mesmo estabelecendo estas diferenças, a academia reproduz os conhecimentos e técnicas da prática médica vigente nos serviços de saúde, e ao mesmo tempo as concepçōes médicas são, também, construidas nesta prática.

A capacitação do médico funda-se em conhecimentos relativos ao corpo normal e patológico e em técnicas de intervenção, diagnósticas e terapéuticas, cuja concepção de saúde-doença é estritamente biológica. Há algumas disciplinas na escola médica que discutem uma concepção mais abrangente que incluem o olhar social - coletivo, mas estas áreas são, absolutamente, contra hegemônicas e pouco influenciam na formação dos profissionais.

A educação médica fornece subsídios, aos estudantes, para identificar o que foge do funcionamento regular do corpo, com a finalidade precipua de aplicar "técnicas de manutenção e recuperaçăo" para o retorno da homeostase.

A transmissão dos conhecimentos técnicos-científicos para o estudante de medicina, que será o trabalhador médico de amanhã, utiliza, entăo, concepçōes de saúde- doença que foram elaboradas para entidades biológicas que funcionam da mesma forma e, portanto, os leva a atuar sob bases "técnicas iguais, em sua essência, para o conjunto dos corpos". Desse modo, "reproduz - se na qualificação do trabalhador médico a concepção ideológica da igualdade social dos corpos" (98).

Nas faculdades de medicina, a prática hospitalar foi se definindo como a melhor maneira de se concretizar a educaçăo médica e este serviço se organizou de modo a se estruturar enquanto um hospital-escola mas que também, produz serviços. Importante ressaltar que ao se estruturar esta prática no hospital, houve a necessidade de se estabelecer um espaço para o trabalho intelectual, que se dá então nas chamadas disciplinas básicas.

Desta forma, o ciclo básico é o espaço da educação e o ciclo clínico se configura como o espaço da prática. Tal e qual se dá no ensino tradicional, em um 
primeiro momento se aprende os conteúdos teóricos, para no segundo momento aplicar o que se aprendeu. Também mostra a dicotomia entre o trabalho intelectual e manual ou, ainda, a cisão entre a educação e a prática.

Apesar da realização das atividades práticas no ciclo clínico, nenhum dos médicos entrevistados apontou que houve aprendizado durante o internato, quando disseram que aprenderam "colocando a måo na massa" estavam se referindo ao período da residência médica. Uma das possíveis razões é a descrita por Rosauro em um artigo apresentado em um simpósio realizado na Santa Casa de São Paulo, onde um aluno de $5^{\circ}$ ano traduziu o interno da seguinte forma: " $O$ que é um interno? Um interno não é um aluno e também năo é médico. Ou seja, um interno não é nada!" (91).

A maneira uniforme, neutra e cientifica de se entender o corpo leva o trabalhador médico à necessidade de reprimir os "afetos" que porventura venha a estabelecer com o doente "... são pacientes crónicos... eles acabam tendo um vínculo além do profissionalismo, que muitas vezes voce tem que tentar esquecer, tentar ser o profissional o máximo possível...." Ou seja, ser profissional significa usar a ciência, tratar todos os corpos da mesma forma, esta é a melhor maneira de se realizar a medicina....

O aprendizado no hospital-escola proporciona esta prática científica, à medida que todos os doentes que ali chegam vestem a mesma roupa, são submetidos aos mesmos horários de alimentação e higiene corporal. Todos os medicamentos são fornecidos nos horários determinados e em quantidade necessária e suficiente para o tratamento. Portanto há uma prática uniforme, não há necessidade de se questionar sobre a vida desta pessoa fora da instituição hospitalar. Neste local todas as variáveis possíveis são controladas com a finalidade da melhora do quadro patológico deste corpo.

Esta forma, atual, de organizar a prática hospitalar que se confunde com a maneira de formar um trabalhador médico, está apoiada no "modelo operativo da ciência" que foi fundado por Descartes e Bacon, e posteriormente reforçado e aprimorado por Abraham Flexner em 1910. Como observa Siqueira este "modelo cartesiano de medicina" é competente para usar tecnologias cada vez mais 
sofisticadas, realizar diagnósticos de patologias que o doente ainda não se deu conta; mas não ensina sobre o "significado metafísico da vida e da morte" (103).

Em um estudo realizado em faculdades de medicina norte americanas publicado em 1995, Hill identificou, entre 126 escolas, 5 que discutiam a morte; e dos 7048 programas de residência médica somente 26 abordavam este tema em suas reuniōes científicas. Apesar de não ter identificado trabalhos semelhantes no Brasil, esta realidade não deve ser diferente ${ }^{(41)}$.

Mas chama atenção o que ocorre na Faculdade de Medicina de Marilia. Há 6 anos realizou-se uma mudança curricular em todas as séries do curso médico. Do $1^{\circ}$ ao $4^{\circ}$ ano os alunos tèm todas as disciplinas de forma integrada utilizando problemas que, de alguma forma, guardam relação com apresentaçăo de casos clínicos. Mas, o que chama atençăo é que de todos os casos estudados, pelos alunos, somente, 2 morrem.

Portanto ser educado para "ver" o corpo somente do ponto de vista biológico e interpretar a vida somente por este prisma, incorporar toda a tecnologia disponivel para este fim passa a ser mais do que um objetivo, passa a ser a grande utopia onde a morte não é e não pode ser reconhecida.

Segundo Sayd, o médico é formado para combater e dominar os fatos naturais, e a própria sociedade "não demanda ao médico que ele ensine a aceitação da morte..." ao contrário ela demanda que ele faça a morte desaparecer do cotidiano. Portanto, o trabalhador médico, muito de acordo com a medicina tecnológica vigente, se encarrega do ocultamento da morte ${ }^{(96)}$.

No estudo realizado por Sayd na Faculdade de Ciências Médicas da Universidade do Rio de Janeiro em 1989, onde ela entrevistou 40 estudantes de diferentes séries, ao acaso, encontrou vários discursos que a levaram a concluir que ao estudante de medicina cabe descobrir o que está errado no corpo do doente. Mas, não está capacitado para "ler a proximidade da morte", pois isto seria a "confissão de impotência frente a natureza" (99). Grande parte do aprendizado objetiva vencer a impotência.

Cada vez mais os hospitais universitários atendem doentes graves, casos raros e em fase terminal da vida. Os estudantes de medicina convivem com estes 
doentes e ao aplicar a tecno - ciência conseguem abstrair completamente que esta doença está acometendo um doente que irá morrer. Ao estudante ensina-se então, em grande parte das vezes, que a morte não faz parte de seu trabalho.

O currículo do curso de graduação não proporciona ao médico a competência de saber cuidar de alguém que está morrendo e de assistir alguém falecido e à sua familia. Assim a DO fica solta, não faz sentido...Somente terá significado na residência médica, dependendo da especialidade, onde o profissional, obrigatoriamente, mesmo que na graduação não tenha adquirido competência para tal, "na pressão da prática" e esta prática envolve pessoas que morrem, ele é obrigado a preencher os AO. Porisso mesmo conhecendo o doente, tendo sido o médico que $O$ atendeu, ainda assim há DO incorretas, incompletas, com causas de óbito mal definidas.

Desta forma, colocar as aulas de preenchimento da DO aqui ou ali, na medicina preventiva ou na legal ou ainda na clínica, possivelmente terá um pequeno impacto na qualidade dos atestados de óbito, uma vez que no curso médico além, de não se aprender a cuidar das pessoas que morrem aprende-se a ocultar a morte ${ }^{(96)}$.

Esta constataçăo de que na faculdade se aprende a se esquivar da morte, parece contrariar a observação de que os alunos iniciam o curso médico, na disciplina de anatomia, estudando em um cadáver. Mas esta contradição é apenas aparente, pois segundo Kovács neste espaço o estudante entra em contato com doença e a morte "descaracterizadas" e "despersonalizadas". E acrescenta, que cabe ao "futuro médico" ... "reprimir qualquer sensação de repulsa, nojo ou desespero" (44). Quando, ocasionalmente, ocorre do estudante não conseguir conter os seus sentimentos ele é visto como alguém que, possivelmente, não estará apto para ser um bom profissional. 


\section{V.2.1.e. Tema IV - Medo de preencher a DO em relaçāo ao seu caráter legal.}

Para a investigaçăo desta hipótese havia uma pergunta especifica no roteiro de entrevista. Os DSC ficaram polarizados entre os que se preocupam com o caráter legal do AO e os que este fato náo causa espécime, mas o que os diferenciam, fundamentalmente é o fato de conhecerem ou não o doente que veio a morrer.

Há mais ou menos 10 anos atrás o municipio de Marília mantinha um plantão de médicos ligados à saúde pública para preencherem atestados de óbito de pessoas que morriam em domicilio de causa natural. Muitas vezes este individuo era levado, às pressas, aos hospitais da cidade e lá chegando ou já havia morrido, ou morria instantes depois da intemação. Mesmo assim, os médicos que estavam de plantão no Pronto-Socorro se recusavam a assinar estes atestados de óbito, acionando, entáo, a equipe da saúde pública. Após várias discussōes com o apoio da legislação vigente e principalmente do Código de Ética Médica ${ }^{(20)}$ que reza em seu capitulo X - Atestado e Boletim Médico artigos 114 e 115, respectivamente, que é vedado ao médico: atestar obito quando năo o tenha verificado pessoalmente, ou quando náo tenha prestado assisténcia ao paciente, salvo no último caso, se o fizer como plantonista, médico substituto ou em caso de necropsia e verificaçáo médico - legal; e deixar de atestar óbito de paciente ao qual vinha prestando assistencia, exceto quando houver indicios de morte violenta; estes médicos aceitaram, porém à contragosto, preencher estes atestados.

E o DSC demonstra esta insatisfaçăo, ainda hoje:..."eu sei que por lei deveria existir um Serviço de Verificaçăo de Óbito em qualquer municipio do meu país. Mas ele não existe... Alguém determinou... Não sei se foi CRM que o médico que (es)tiver na porta de um hospital vai fazer verificação de obbito...."

Neste momento, o entendimento dessa recusa fica um pouco mais claro. Havia $\theta$, ainda há, um "medo inconsciente de entrar em contato com a morte $\theta$ com o sentimento de impotência" ${ }^{\left({ }^{\circ}\right)}$. E este medo da morte convive com o da 
necessidade de se ter que prestar depoimento na justiça: “...medo... De preencher errado, ter que depor, ter que ir num tribunal. Preocupa, às vezes eu não sei direito como escrever e voce pode ser chamado para esclarecer".

Interessante observar que ao serem questionados se conheciam algum colega de profissáo que havia sofrido alguma punição em função do preenchimento inadequado da DO, a resposta, invariavelmente, foi negativa.

Alguns colocaram que já haviam sido chamados para depor, mas náo tinham conhecimento de sançóes imputadas a médicos. Mesmo assim, aparece no discurso do sujeito coletivo que a lei pode interpretar de forma diferente o diagnóstico médico colocado, "qualquer coisa que se coloque em termos de diagnóstico pode ser levado em termos legais para outras interpretaçסes".

O que os médicos estão sentindo é o fenômeno de " jurisdicizaçăo social" que significa, em linhas gerais, adaptar o conjunto de decisōes e interpretaçōes legais às situações de fato. Este fenômeno tem como autores os advogados que vêem se destacando na vida dos brasileiros desde a aprovaçăo da Constituiçăo de 1988. Essa representou um marco no processo de redemocratizaçăo do país, levando ao que Barbosa chamou de uma "redefiniçäo da legalidade" (ต). Fato semelhante ocorreu na constituição do Estado francês, segundo Bourdieu onde os advogados tiveram um papel de relevância na construçăo das concepçöes atuais de legalidade e cidadania ${ }^{(11)}$.

O jornal da Associação Paulista de Medicina ( out/2002) publicou um artigo relatando um seminário que teve a participação de advogados e médicos onde se discutiu esta jurisdicização. Udelsman apontou que de "95 a 2001 houve um aumento de $75 \%$ de queixas contra os médicos " (110).

Todo este processo é favorecido à medida que a sociedade contemporânea, diminuiu a sua passividade frente à situaçóes adversas e entre elas às doenças e morte. Assim, como em muitos casos já se consegue vencer doenças e afastar a morte com o uso de tecnologia moderna, quando ocorre um insucesso este é encarado como imperícia e ou negligéncia por parte dos profissionais médicos. 
Além disso, a mídia contribui com a jurisdicização pois é um veículo, tanto para disseminar conhecimentos à respeito de saúde e dos direitos dos cidadáos, como para divulgar procedimentos inadequados realizados pelos médicos ${ }^{(\sigma)}$.

Juridicamente a morte é conceituada como o "desaparecimento permanente de todo o sinal de vida". Com o avanço tecnológico da medicina este conceito precisou ser ampliado, principalmente, devido à possibilidade da realização de transplantes de órgãos ${ }^{(4 \pi)}$.

No Brasil, a lei $n^{\circ} 8489$ de 18 de novembro de 1992, regulamentada pelo decreto $n^{\circ} 879$ de julho de 93 , é que define o óbito com a possibilidade de transplante. 0 seu artigo $3^{\circ}$ inciso $\mathrm{V}$ coloca que morte encefálica, é a morte definida, como tal, pelo Conselho Federal de Medicina e atestada por médico. Em seu parágrafo único : a definição de morte encefálica, a que se refere o inciso $V$, não exclui os outros conceitos de condição de morte. Pelo exposto nesta lei e seu respectivo decreto verifica-se que o diagnóstico de morte é o referido pelo Conselho Federal de Medicina, assim, teoricamente, não há porque temer, não é a Justiça que está definindo e sim um órgão ligado à categoria médica.

O médico é o encarregado de preencher e assinar o atestado de óbito, respondendo por todas as informaçōes que constam desse documento. $E$ não como aparece no discurso "..Se a gente pensar no atestado, só naquele pedacinho que é a parte médica...". Uma prova do fato que o médico é responsável por todos os dados do atestado é que o campo com as informaçōes do profissional não está ligado ao item VI da DO, que trata das causas da morte, mas vem como um campo à parte, uma vez que se refere a todas as informaçőes contidas naquele.

Quando é uma morte devido a um acidente ou qualquer tipo de violéncia, causas que a Organização Mundial de Saúde denomina de causas externas, o Instituto Médico Legal é acionado para realizar a necropsia, emitir o laudo e preencher a DO. Somente após estes procedimentos é que será possivel o sepultamento, uma vez que a certidão de óbito é imprescindivel para que este ocorra ( Lei Federal 6015, artigo 77 de 31/12/1973) ${ }^{(47)}$. 
As pessoas que morrem sem ter tido assisténcia médica em locais que não apresentam um Serviço de Verificação de Óbito constituído, como é o caso do município onde se realizou este estudo, o médico que constata o óbito năo terá elementos para estabelecer um diagnóstico, assim sendo, colocará no campo VI óbito sem assistência médica (causa mal definida). Portanto, para este caso se terá um "atestado de óbito e não um atestado da causa do óbito" (47).

No trabalho realizado por Baggio $^{(3)}$ do total de óbitos classificados como causas mal definidas e residuais de capitulo, $75,7 \%$ deles foram corrigidos, ou seja eram pessoas, que apesar de terem morrido em domicílio ou em internação precoce, onde o médico plantonista alega que não conhecia o doente, estavam sendo acompanhadas nos serviços de saúde e muitas vezes no próprio hospital onde o médico é plantonista. Possivelmente, em funçăo dos sentimentos gerados, "eu tenho medo de implicação legal ..", e da característica da formaçáo do trabalhador médico, anteriormente discutidos, os profissionais optam por preencher as DO como um trabalho meramente burocrático.

A grande preocupação é ".no sentido de voce deixar as coisas bem mais claras e de uma forma incontestável, até para que isto náo venha resultar futuramente não só para voce mas para a familia também, pois para a familia $\dot{e}$ muito importante o seguro de vida quando a pessoa morreu..."

Hoje, o maior transtorno que os médicos têm é o de dar satisfação para as seguradoras e pode ser que isto seja confundido com os aspectos legais ligados à morte. Obviamente há leis que regem o funcionamento dos seguros privados, mas cada empresa tem cláusulas especificas. Como toda empresa privada, no modo de produçáo capitalista, quanto menor a quantia a ser paga maior o lucro da empresa. Portanto, os agentes das seguradoras têm grande interesse em provar que aquela causa colocada no atestado é passivel de erro ou é uma causa não prevista no contrato realizado.

Desde o início do século $X X$. Torres, um médico do Rio de Janeiro , solicitou permissão à Diretoria Geral de Saúde, para os médicos omitirem o diagnóstico nos atestados de óbito quando não fosse possivel ter certeza da causa de morte. Mas esta proposta foi altamente rejeitada uma vez que crimes 
poderiam ser ocultados da justiça. Ele propôs, então, a criação de um grupo de médicos que verificassem os óbitos e que fossem habilitados para realizarem exames necroscópicos ${ }^{(108)}$.

Em 1931 criou-se através do Decreto Estadual n.` 4967 o SVo de São Paulo, em 86 com a Lei $n^{\circ} 5452$ houve a reorganização dos SVO do Estado de São Paulo que permitia estender este serviço para outros municípios do Estado mediante credenciamento pelo SVO da capital ${ }^{(1)}$.

A necessidade de se ter um SVO, como apontam alguns profissionais, possivelmente, traz o medo de se trabalhar com a morte e o de ser punido por inadvertidamente ter atestado uma morte criminosa, ou ainda de colocar às claras que não cumpriu com o seu papel de curar.

O médico tem na autonomia o principio fundamental de sua profissão; esta autonomia significa liberdade de ação. Interessante verificar que ao mesmo tempo que ele luta pela autonomia, ele rejeita a responsabilidade que estas açöes autônomas podem gerar, principalmente, quando no final deste caminho está a morte. Ao reinvidicar o direito de lidar com a totalidade do processo vital, deve se trabalhar com a vida e com a morte, pois ambas fazem parte do mesmo processo.

A filosofia mostra a ligação que existe entre liberdade (autonomia) e responsabilidade. Savater ${ }^{(\infty)}$ nos adverte que há, atualmente, muitas teorias que se pode utilizar para se desculpar quando o peso da responsabilidade se toma um problema : "o mérito positivo de minhas açסes é meu, mas minha culpa eu posso dividir ....com a situação histórica, com o sistema econômico..." e os médicos diriam que a "culpa" de se ter DO mal preenchidas "....é uma falha que não é minha, é ...do sistema que está aí..."

Os profissionais, em geral, mas mais especificamente os que atuam em serviços de urgência/emergência, querem garantir os principios da prática autônoma e ao mesmo tempo lutam para que o Estado, aqui representado pelo poder local, assuma o seu papel e estruture SVO para os doentes que ele não conheceu, esquecendo-se que, com honrosas exceçōes, esta pessoa era um cidadão atendido por outros médicos nos serviços de saúde, tanto públicos corno privados. 


\section{IV.2.1.c. Tema IV - Dificuldade para lidar com a morte.}

Como então lidar com os diferentes sentimentos e principalmente com a morte? Os médicos discutem três modos aparentemente distintos de se trabalhar com este aspecto de sua prática. Um condiciona o sentimento a diferentes aspectos da vida, principalmente à idade, "o paciente é um velho.... vai morrer.... tem um câncer generalizado". Segundo Elias, as pessoas mais jovens têm dificuldade para "estabelecer uma relaçăo de empatia" com pessoas idosas, uma vez que lhes é penoso imaginar, mesmo porque não se quer imaginar, que eles próprios podem um dia ter sensações de cansaço, lentidão e talvez doenças. "De uma maneira consciente ou inconsciente, a gente resiste por todos os meios à idéia de sua própria velhice e de sua própria morte" (31).

$\mathrm{Na}$ segunda representação a idéia de preencher uma DO é de tristeza, de perda, de dificuldade de se lidar com a morte, independente de qualquer coisa. $O$ fato de ter que se deparar com este sentimento nos momentos em que se preenche um $A O$, possivelmente, o faz reviver experiências infantis sofridas, mesmo que estas sejam inconscientes ${ }^{(31)}$.

Olhar para um doente grave ou morto provoca os mecanismos de defesa que as pessoas construíram para se proteger da idéia de sua própria morte. Elias coloca que "o amor a si mesmos thes sussurra ao ouvido que săo imortais". " ...não consigo sentir a morte como Náo sendo uma coisa ruim.." Um dos profissionais colocou que hoje sabe que buscou, na área médica, uma forma de se proteger da morte.

Este fato já foi relatado em outros trabalhos, Sayd descreve um dos depoimentos de um aluno de $1^{\circ}$ ano de medicina : "Tenho pavor da morte. $E$ até, talvez, uma razão de estar fazendo medicina. Detesto a minha morte. O que eu tenho mais medo é de saber que algum dia alguém vai morrer na minha mâo" (98).

Vida e morte para os seres humanos são "acontecimentos simbólicos", uma vez que apresentam um sentido. Com a vida e com a morte os seres humanos se descobrem finitos. Morrer é um ato solitário e viver é estar com os outros, como discute Chaui (22). 
Portanto a relação médico - paciente só existe enquanto o individuo está vivo, pois somente neste estado ele é capaz de estabelecer relaçōes; quando se morre o que fazia sentido para aquela relação termina, ficando somente o seu espectro, ou seja, fica o que se construiu anteriormente. Por isso que quando o médico não conhece o doente, além de não saber do que ele morreu, ele pode se sentir desobrigado com aquele ser que já não é mais capaz de manter um vínculo.

Levando em conta estes aspectos, Savater coloca que o que torna as pessoas verdadeiramente humanas é a certeza pessoal da morte, e é este fato que transforma as pessoas em seres viventes. E continua dizendo que "a morte serve para fazer pensar, mas não sobre a morte e sim sobre a vida ${ }^{(95)}$.

Vários estudos realizados com estudantes de medicina e/ou médicos apontam para a dificuldade que estes apresentam em trabalhar com a morte, em encará-la como fazendo parte do processo da vida ${ }^{(\infty 6)}$.

Este sentimento ocorre sobremaneira com os médicos pois além de serem pessoas que vivem nesta sociedade que reprime o pensamento da morte, também foram formados para tratar, curar, recuperar uma pessoa $\theta$ até para se pensar como um recurso terapêutico, mas nunca para cuidar das pessoas que estão morrendo, proporcionando-lhes uma morte digna, onde a declaração de óbito passa a ser o instrumento que documenta este momento final, que é individual e intransferivel, e que ao mesmo tempo integra as mortes ocorridas na populaçăo que documentam análises coletivas. 


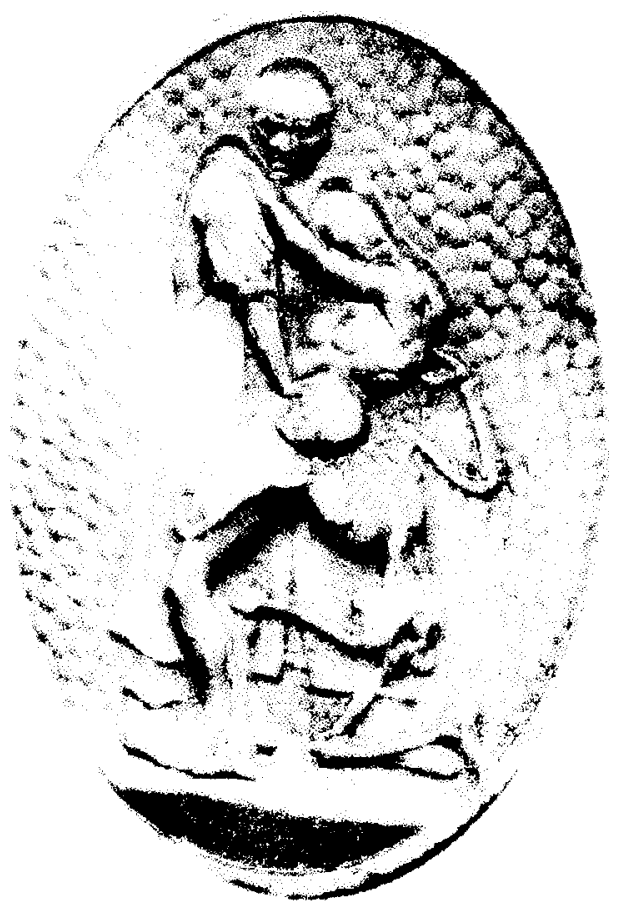




\section{CONCLUSÕES:}


Como o objetivo geral deste trabalho foi o de avaliar os campos de informações que fazem parte da declaração de óbito, descrevendo os fatores que podem interferir no preenchimento desse instrumento, junto aos médicos, destacaram-se, neste tópico, os pontos de contato entre a fase quantitativa e a qualitativa.

\section{$\Rightarrow$ Escolaridade, ocupação e estado civil}

Ao se estudarem os GRUPOS na fase 1 deste trabalho, levantou-se em praticamente todos eles, os itens: escolaridade, ocupação e estado civil. Esses foram os que apresentaram maior número de campos em branco e lou ignorados.

Os trechos dos DSC, colocados abaixo, apontam que os médicos não se consideram responsáveis pelo preenchimento desses itens, mesmo porque, a não ser no IML, são as pessoas ligadas ao setor de internação ou serviço social que completam esses dados.

"Se a gente pensar no atestado, só naquele pedacinho que é a parte médica, ele é uma conseqüência do ato médico, você tem que cumprir um papel que é do médico... intransferível."

“O preenchimento do atestado é complicado não só por parte do cabeçalho, que geralmente é o hospital", ou ainda,

"No hospital normalmente o serviço social preenche a DO, e sobra para nós só o atestado, no IML não, no IML preenchemos de cabo a rabo, então aí fica mais....(complicado)."

Além disso, os médicos também desconhecem os objetivos desses dados na elaboração das informaçōes de mortalidade. Quando questionados quanto às finalidades da DO, foram capazes de citar somente duas variáveis, além das causas de morte, a idade e ser gestante, que poderiam ser utilizadas nas estatísticas de mortalidade. 
"...Presta, ainda, para fazer levantamento do que é mais comum, se é violento ou não, da incidência de óbito em gestante, a idade e no caso de doenças que podem gerar processo de epidemias."

Um outro ponto que pode ser abordado, apesar de não ter sido objeto deste trabalho, é a estrutura da DO, que pode dificultar o preenchimento desses itens, principalmente quando se trata de mortes fetais e de menores de 1 ano, pois a orientação é o não preenchimento, quando poderia ficar mais claro se o instrumento contasse com um campo de não procede ou não se aplica.

\section{$\Rightarrow$ Aumento das mortes mal definidas}

Ao se avaliar o número de mortes mal definidas no periodo de 9 anos, verificou-se que ele vem aumentando. Uma das causas diz respeito ao medo de se preencher a DO à medida que ela é um documento que envolve uma questão legal.

O DSC deixa claro que o médico usa algumas estratégias para mostrar esse sentimento: "..Quando eu preencho esse atestado eu coloco que estou fazendo verificação de óbito, eu não coloco que eu sou o médico, sou substituto... nada... No quadrinho eu ponho lá... que eu sou do SVO, porque se alguém me questionar eu falo que eu vi uma paciente que chegou na porta do hospital, examinei... não tinha lesão nenhuma externa... e eu coloquei como sendo morte de causa desconhecida, ou morte em trânsito, pronto... eu não sei de nada.. É uma forma de fugir do medo...."

“... Bom, eu tenho medo de assinar qualquer coisa. Porque hoje em dia o que a gente vê aí de processo deste tipo de coisa. Você tem que estar mais atento para isto porque qualquer detalhe ou qualquer coisa que se coloque em termos de diagnóstico pode ser levado em termos legais para outras interpretaçóes."

Como já analisado anteriormente, esse medo procede em funçăo do processo de jurisdicização que a sociedade brasileira vem passando, mas ao 
mesmo tempo isso deve ser relativizado uma vez que, do ponto de vista legal, o órgão que define a morte é o próprio Conselho Federal de Medicina.

\section{$\Rightarrow$ Local da morte e o médico que assinou a DO}

Comparando-se os grupos de causas mal definidas com as bem definidas, segundo as variáveis de local de morte, hospitalar ou domiciliar, e se o médico que assinou a DO foi o mesmo que assistiu o doente, verificou-se o seguinte: nas causas bem definidas, $86 \%$ (307) dos doentes morreram no hospital contra $5 \%$ de óbitos que ocorreram no domicílio. Das mortes hospitalares, em $75 \%$ o médico que assinou a DO assistiu o doente. Interessante observar que nos óbitos domiciliares a porcentagem é semelhante à hospitalar $(77,7 \%)$.

Já nas mal definidas ocorre o inverso, 60,7\% foram mortes domiciliares contra $22 \%$ de hospitalares. Em somente $6 \%$ das mortes que ocorreram no âmbito domiciliar o médico havia atendido o doente. Esses fatos chamam muito atenção quando, por diversas vezes nos DSC, apontou-se que fatores facilitadores no preenchimento da DO eram o fato de se conhecer o doente, de saber sua patologia de base, e de reconhecer que a relação se estreitava quando o doente estava hospitalizado. Portanto, saber do doente, conhecê-lo, possivelmente, apresenta estreita relação com DO com causas bem definidas.

“...Para nós aqui que estamos em um hospital grande, é fácil, se tem dúvida vai lá e pega o prontuário e lê.. é possível, né? Os doentes que são do nosso ambulatório a gente também conhece, também não tem dificuldade..."

"....normalmente são meus clientes, pacientes que eu cuidei na enfermaria e que por tudo isso, você cria um vínculo médico-paciente ...."

“...Além disso, ... na hora do óbito, geralmente a gente tá presente e aí a hora que você constata a gente mesmo pede para trazer o atestado e preenche e já assina, nunca tive grandes dificuldades em relação a isso...."

“...E como são pacientes crônicos eu tenho uma noção de quais pacientes eu devo perder no próximo mês, no próximo trimestre, porque é um 
evento, até certo ponto, previsto, é lógico que acontece algumas exceções, mas habitualmente você prevê tudo isso e acaba não interferindo...."

Como grande parte das pessoas que morreram no municipio foram atendidas principalmente nos serviços públicos de saúde, deve-se novamente observar a análise de modelo assistencial e a prática médica, uma vez que o modelo de organização atual não pressupõe que a equipe de saúde $e$, particularmente o médico, se ocupe das pessoas que estão em fase terminal e que morrem na área de abrangência de responsabilidade do serviço de saúde.

Dessa maneira, quando o doente morre e isso ocorre no domicílio, a família não tem outra opção a não ser acionar a equipe de resgate para levar o corpo para os serviços de urgência do município. Lá chegando o médico não conhece o doente e "....Então, pelo que eu sei até onde vai .. você é obrigado a dar $A O$, você constatou, mas você não é obrigado a saber do que o sujeito morreu..."

Teoricamente, à medida que o serviço de saúde é responsável por um determinado território, respondendo pelos processos de vida e morte das pessoas que aí vivem, também, deveriam responder pelo preenchimento da DO.

Por outro lado, quando se observa que das 23 mortes que ocorreram no hospital cujas DO eram residuais de capitulo (total de 25), e que em praticamente $70 \%$ delas o médico que assinou o atestado foi o mesmo que prestou assistência a conclusão para esses diagnósticos incompletos pode se encaminhar para a falta de conhecimento quanto ao preenchimento do $\mathrm{AO}$ ou das dificuldades em relação à morte.

Esses dois elementos também foram encontrados nos DSC. O primeiro apontado, através das três IC, é que: "teoricamente aprendi na medicina preventiva e/ou medicina legal, mas foi pouco, acaba se perdendo pois não se pratica já que é em momento inadequado". Na verdade, o que os médicos mostram nesta IC é que, na graduação, eles não aprenderam a preencher as DO, eles tiveram aulas a respeito do tema, mas que não significou aprendizado.

De fato, o conhecimento ocorre: " ....na residência médica, com os $R 2$, e nos cursos de pós - graduação/ especialização", complementando "...com a pressão da prática, ora em conversas com quem transcreve as DO e com 
colegas mais antigos, utilizando o próprio impresso como guia, ora utilizando - manual, mesmo assim tenho dúvidas." Nessa última IC, verifica-se a importância da estrutura do impresso no preenchimento da DO, uma vez que ele serve de "guia" para os profissionais.

Em relação ao sentimento que assinar uma DO gera, os DSC apontam que “...Se eu prestei assistência médica para ele, ora sinto com a missão cumprida de ter feito o que eu pude pelo paciente, ora tem o infortúnio de não ter conseguido fazer tudo o que podia...". Outro grupo de médicos encara a morte como “... um evento natural, um evento que a gente não consegue escapar, né? Acho que a parte afetiva fica de lado, entendeu?" Já outros profissionais colocam que "...No momento de você assinar o $A O$, ....há uma sensação de perda, uma vez que os meus óbitos são de pacientes conhecidos... de longa convivência." E acrescentam... "É quando me sinto impotente eu descobri naquela hora que eu não sou nada... Me sinto muito mal....".

Não foi possivel, neste trabalho, relacionar, diretamente, esses sentimentos apontados acima que vão desde à indiferença, passando por alguns fatores mobilizadores, chegando ao sentimento de impotência, com o preenchimento da DO. Mas não é absurdo supor que essas emoções, que estão presentes no momento da morte e do preenchimento da DO, tenham um papel relevante.

\section{$\Rightarrow$ Dificuldade de estabelecer nexo causal e a causa imediata da morte}

Em todos os grupos de DO, verificou-se que havia atestados com seqüência de causas de morte comprometidas, variando de $26,3 \%$ no GRUPO de mulheres de 10 a 49 anos, a $89 \%$, no das causas residuais de capítulo.

Alguns DSC apontaram a dificuldade de se estabelecer a causa imediata da morte, bem como as conseqüenciais, pois, algumas vezes, várias patologias podem ser coadjuvantes no processo de morte sem, no entanto, uma ser conseqüência da outra. Os médicos discutem também que, às vezes, não 
conseguem sintetizar todo o quadro que o doente apresentava de forma a colocá lo em uma seqüência lógica.

"...Eu acho que a maior dificuldade no preenchimento é, realmente, saber o diagnóstico que levou, diretamente, a morte do doente. ..., geralmente, quando o paciente chega grave nunca tem certeza do que ele morreu. Se é um tromboembolismo, não tem os exames auxiliares para confirmar o diagnóstico, então você... Se você tá acompanhando paciente que tá estável, de repente ele tem uma dispnéia súbita e morre... por insuficiência respiratória, você põe como causa insuficiência respiratória aguda, então você dificilmente vai colocar um tromboembolismo pulmonar como diagnóstico. Houve uma parada cardiaca, num doente que é seu que tem um monte de doenças associadas, você, realmente, não sabe qual que é... Dificil chegar em um diagnóstico dele a não ser que seja uma coisa simples, uma pneumonia ou alguma outra coisa...."

De alguma forma, eles também estão discutindo a estrutura da $\mathrm{DO}$, à medida que não há espaço suficiente para colocar quadros clínicos exuberantes, ou doenças que, em conjunto, poderiam dar maior nexo causal. 


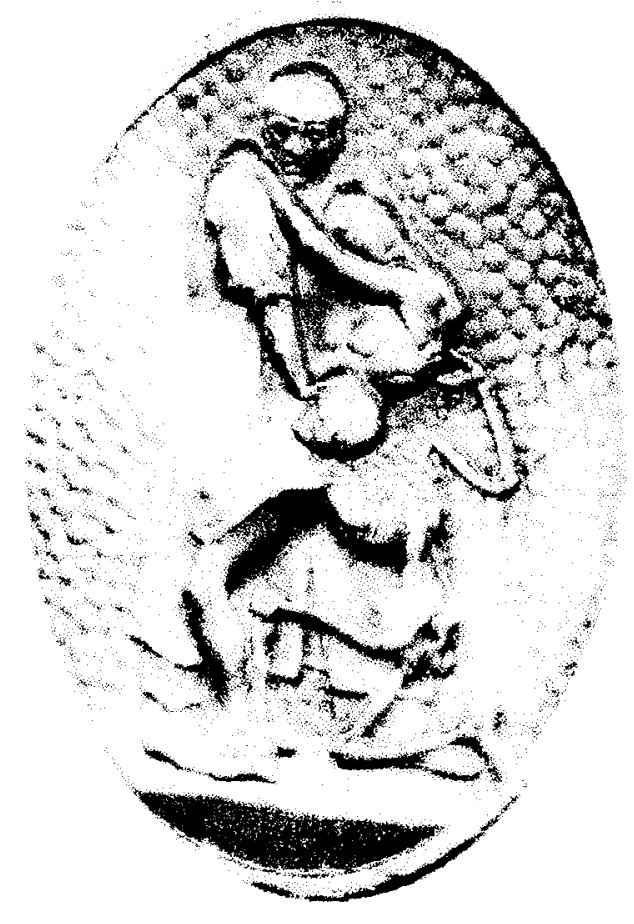




\section{CONSIDERAÇÕES FINAIS:}


A realização de um trabalho deste tipo proporciona muitos aprendizados, sendo que diversos deles estão mais relacionados ao processo da pesquisa em si do que propriamente aos resultados.

A pesquisa quantitativa trouxe muitos elementos durante o seu processo de consecução, desde entrar em contato com os diretores - clínicos dos hospitais para poder realizar a análise de prontuários, passando pelo entendimento do funcionamento de cada um dos serviços, tanto de internação como ambulatoriais para que esses formulários pudessem ser fornecidos para as análises, até a verificação da qualidade da informação em cada um dos impressos. Uma experiência diferenciada foi tentar retirar de cada parágrafo a história de vida e da morte de cada uma das pessoas que foram estudadas, ordenar os dados para transformá - los em informações mais precisas, necessárias e suficientes para uma DO nova.

Pôde - se constatar, através dos prontuários, que muitas pessoas, no período que antecedeu a morte, procuraram os serviços de saúde, principalmente os de urgência/emergência, com queixas que de alguma forma resultariam na morte, entretanto pouco foi feito por elas, a não a instituição de tratamentos sintomáticos.

Nesses mesmos prontuários, houve a oportunidade de se verificar que a família informava o que o doente apresentava, mas que essa informação, via de regra, não foi levada em conta.

Posteriormente, ir às casas dessas famílias, ser recebida por alguém, ainda triste pela perda ou magoada com o mal atendimento dos serviços de saúde, outras vezes grata pela assistência recebida do médico, proporcionou, com freqüência, conhecimento maior do significado do processo de viver e, até mesmo de morrer.

Às vezes, o bom atendimento do serviço de resgate era apontado e havia o sentimento de que tudo havia sido feito por aquele ente querido, outras vezes ele não era tão querido assim e havia dificuldade em se falar a respeito. 
Em alguns momentos, os endereços foram dificeis de serem localizados, pois a morte da pessoa fazia com que os demais se mudassem, algumas vezes de bairro e outras de municipio.

$\mathrm{Na}$ pesquisa qualitativa aconteceram outras descobertas surpreendentes. Uma delas foi a disponibilidade e a necessidade dos profissionais em falar a respeito do assunto em questão. Praticamente nenhum deles se importou com o tempo da entrevista, com o fato dela ser gravada e se colocaram abertamente.

Realizar este trabalho, concatenando a pesquisa qualitativa com a quantitativa apresentou-se como uma ampliação de horizontes. Foi muito gratificante perceber que os dados encontrados na fase quantitativa tinham lógica e ganhavam significado por meio dos DSC.

Em função dos resultados obtidos, este estudo propõe quatro frentes de atuaçāo: a primeira no desenvolvimento de uma linha de pesquisa para aprofundar estas análises e gerar novos elementos e frentes de ação; a segunda, junto às Faculdades de Medicina do município; a terceira, junto à Secretaria Municipal de Higiene e Saúde; e, por último, inserir o conceito de morte no cotidiano dos serviços de saúde em geral.

\section{1- Linha de Pesquisa:}

$\Rightarrow$ Realizar novos estudos nesta área, identificando os médicos segundo os GRUPOS estudados na fase quantitativa, com o objetivo de verificar se os DSC mudam de acordo com os GRUPOS de causas. Possivelmente, se conseguirá gerar novos elementos de análise para subsidiar, continuamente, as demais frentes de atuação. 


\section{2- Faculdades de Medicina:}

$\Rightarrow$ Parte-se do princípio que para realizar bem uma atividade é necessário: ter conhecimento das teorias que a embasam, saber de sua finalidade e ter habilidade para articular todos esses saberes. Essa habilidade de articulação é o que se denomina competência. Mas para que este aprendizado ocorra, o conhecimento científico socialmente construido (teorias) deve ter significado para o estudante.

O preenchimento de uma DO é um desempenho que faz parte de uma competência médica que é a de saber assistir uma pessoa que morreu. Para garantir essa competência é necessário ter alguns desempenhos, tais como: saber preencher uma DO, conhecer suas finalidades, saber orientar $\Theta$ acolher os familiares, providenciar os cuidados necessários ao falecido, entre outros. Dessa forma, poderia se propor para as Faculdades de Medicina do município a inserção, em sua grade curricular, de uma competência que seja : saber assistir - cuidar de um indivíduo que morre, sendo o preenchimento da DO um dos desempenhos a serem apreendidos dentro dessa competência que lhe dá significado.

$\Rightarrow$ Disponibilizar os prontuários para os médicos que dão plantão nos serviços de urgência/emergência dos hospitais.

\section{3- Secretaria Municipal de Higiene e Saúde (SMHS)}

$\Rightarrow$ Criar um Comitê de Mortalidade Municipal que se discutirá, periodicamente, uma amostra das mortes hospitalares e domiciliares. Nas reuniōes desse Comitê participarão o núcleo de informação da SMHS, médicos dos serviços de saúde, gerentes dos hospitais e dos serviços básicos de atenção, residentes e internos. 
$\Rightarrow$ Realizar autópsia verbal, monitorando as DO dos GRUPOS definidos neste trabalho, e retornando a informação para os médicos, criando a cultura da informação, sendo o Núcleo de Informações da SMHS, bem como os grupos técnicos da área da criança e da mulher, responsáveis por esse trabalho.

$\Rightarrow$ Discutir com a Coordenação das Unidades de Saúde da Família (USF) a possibilidade dessa equipe garantir o cuidado ao falecido e à sua família, incluindo o preenchimento da DO. Para tanto será necessário promover a capacitação da equipe, para o desenvolvimento deste trabalho. Essa ação seria realizada, inicialmente pela USF pois essa tenta incorporar, em sua organização de trabalho, as famílias que vivem na sua área de abrangência.

$\Rightarrow$ Disponibilizar as DO para os médicos das ESF e para os que exercem especialidades como oncologia e geriatria, e por isso mais preenchem DO com mais freqüência no município. Essa ação possibilitará um fluxo mais adequado para os óbitos que ocorrem nos domicílios.

$\Rightarrow$ Promover discussões, com a categoria médica, da relação entre a DO e as empresas de seguro, bem como os aspectos legais dos AO. Esses encontros podem ser mediados pelas organizações médicas do município em conjunto com a SMHS.

$\Rightarrow$ Promover reuniōes com os médicos legistas, bem como com os delegados das polícias civil e rodoviária, estadual e federal, para discutir as informações relacionadas aos óbitos por causas externas. 
$\Rightarrow$ Inserir o conceito de morte, como parte da vida, no cotidiano dos serviços de saúde, e nos currículos das escolas que são responsáveis pela formação de novos profissionais.

Essa ação é a última, mas, possivelmente, uma das mais importantes e a de maior complexidade. De alguma maneira passa pela transformação do papel do médico e de sua forma de atuar. Hoje, ele está sendo considerado "uma unidade biopsicológica móvel, portadora de conhecimentos especializados, e que vende serviços."

A sua transformação deve ser no sentido de, além de ser capaz de incorporar tecnologia, ser também, uma pessoa admirada, não pelo seu poder ou pelo seu saber, mas pela sua capacidade de ser humanamente solidário, na vida e na morte, e que, esgotada a sua capacidade de intervenção, espera e medita, convivendo com sua impotência e com a sua finitude.

"(Os médicos) Aprenderam que sua missão é lutar contra a morte. Esgotados os seus recursos, eles saem da arena, derrotados e impotentes. Pena. Se eles soubessem que sua missão é cuidar da vida, e que a morte é parte da vida, eles ficariam até o fim. E assim, ficariam também um pouco mais sábios. E atéimagino - começariam a escrever poesia..." Rubem Alves (O médico - 2002) 


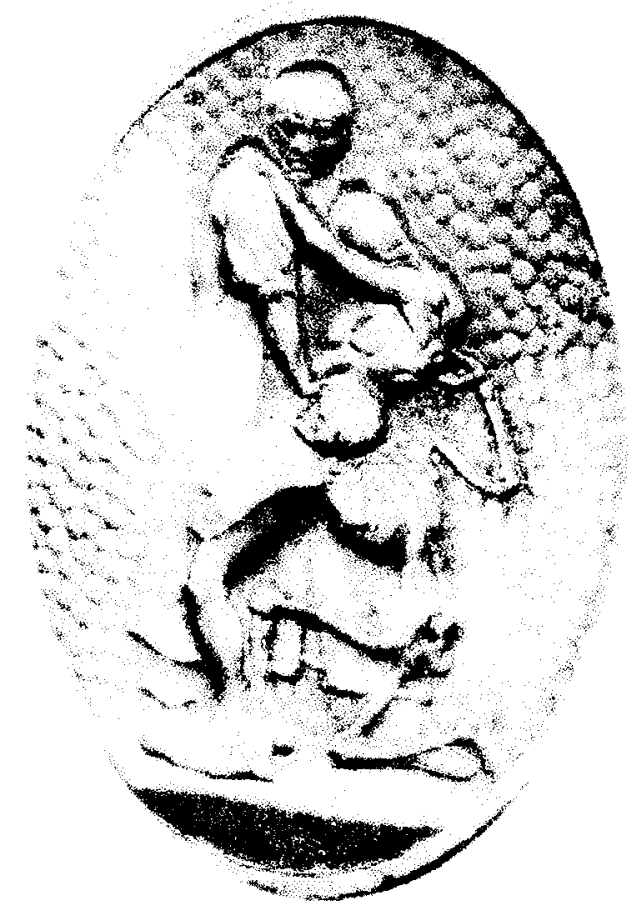




\section{REFERÊNCIAS BIBLIOGRÁFICAS:}


1- Antunes JLF. Medicina, leis e moral : pensamento médico e comportamento no Brasil (1870 - 1930). São Paulo: Fundação editora UNESP; 1998.

2- Attestados de óbito (editorial). Gazeta clínica 1915; $13 / 434$.

3- Baggio MCR. A qualidade da informaçăo de mortalidade em alguns municipios da regional de Marilia - SP: Correçăo de distorçð̌es por meio de técnicas simples. Săo Paulo; 2002. [ Tese de doutoramento_Faculdade de Saúde Pública da USP].

4- Bangdiwala SI, Cohn R, Hazard O, Davis CE, Prineas RJ.

Comparisons of cause of death verification methods and costs in the Lipid

Research clinics program mortality follow-up study. Controlled clinical

Trials. 1989;10(2):167 -187 .

5- Barata RCB. Uso epidemiológico das informações de mortalidade no planejamento e avaliação dos serviços. Trabalho apresentado no Seminário "Usos das informações de mortalidade em nível municipal" CEPI SP 20/11/1992.

6- Barbosa MLO. Para onde vai a classe média? Um novo profissionalismo no Brasil? In: Tempo Social. Revista de Sociologia da USP. v.10, $n^{\circ 1}$ (maio de 1998). SP:USP, FFLCH, 1998.)

7- Barros FO, Victora OG, Teixeira AMB, Puerto M. Mortalidade perinatal e infantil em Pelotas, Rio Grande do Sul: Nossas estatisticas são confiáveis? Cadernos Saúde Pública. 1985;1(3): 348-358.

8- Barros MBA, Araújo M. Espacialização dos óbitos de menores de um ano no município de Campinas. Trabalho apresentado no Seminário "Usos das informaçōes de mortalidade em nivel municipal", CEPI - PM de Săo Paulo, 20/11/92

9- Barros MDA, Ximenes R, Lima MLC. Preenchimento de variáveis nas declaraçöes de óbito por causas externas de crianças e adolescentes no Recife, de 1979 a 1995. Cad. Saúde Pública, jan-fev 2001; 17(1):71-78.

10- Bauer FW, Robbins SL. Na autopsy study of cancer patients.1.Accuracy of the clinical diagnosis, 1955 to 1965 . The Joumal of the American Medical Association 1972; 221(13): 1471-1474.

11- Bourdieu P. Raisons pratiques:sur la théorie de l'action. Paris, editions du Seuil, 1994.

12- Bromberg MHPF. O profissional de saúde e o enfrentamento da morte.

Rev. de Psicologia Hospitalar 1997; 7(1):4-8. 
13- Campos GWS. A clínica do Sujeito: por uma clínica reformulada e ampliada. Mimeo, 1996/1997.

14- Carvalho DM. Grandes sistemas nacionais de informaçōes em saúde: revisão e discussão da situação atual. In : Informe epidemiológico do SUS/ Centro Nacional de Epidemiologia, coord - Brasília: Fundação Nacional de Saúde v (4), out/dez, 1997 7:20.

15- Carvalho ML, Niobey FMC, Miranda NN, Sobroza PC. Concordåncia na determinação da causa básica de óbito em menores de um ano na região metropolitana do Rio de Janeiro. Rev Saúde Pública 1990; 24(2):20-27.

16- Carvalho ML, Silver DS. Confiabilidade da declaraçăo da causa básica de óbitos neonatais: implicaçóes para o estudo da mortalidade prevenivel. Rev Saúde Pública. 1995; 29(5):342-8.

17- Carvalho Neto JA. Certificaçăo médica das causas externas de óbito no Distrito Federal: avaliação do preenchimento das declaraçōes de óbito, 19801994. Brasilia méd 1998; 35(3/4):79-88.

18- Castillo BM, Mardones GA. Certificacion medica de las defunciones em los servicios de salud de Chile. Rev. Méd.de Chile 1986;114:693-700.

19- CDC, WHO. Epi Info: versăo 6 : sistema de processamento de texto, banco de dados e estatística para epidemiologia em microcomputadores. Atlanta, 1994.589p.

20- Cecilio, OC.L. Pensando mecanismos que facilitem o controle social como estratégia para a melhoria dos serviços públicos de saúde. Saúde em Debate 1999 set/dez; 23(53):30-36.

21- Chalhoub $\mathrm{S}$. Cidade febril : cortiços e epidemias na corte imperial.

São Paulo: Companhia das letras; 1996.

22- Chaui M. Convite à filosofia. 12ed, SP: Ed.Ática; 2000.

23- Chaui M. Cultura e democracia: o discurso competente e outras falas. 7ed. São Paulo: Cortez, 1997.

24- Conselho Regional de Medicina do Estado de São Paulo. Código de ética médica, 1988.

25- Diehl AK, Gau DW. Death certificates by British Doctors: A demographic analysis. Journal of Epidemiology and Comunity Health 1982; 36:146-149. 
26- Donnangelo MCF. Medicina e Sociedade: o médico e seu mercado de trabalho. SP:Pioneira; 1975.

27- Dorn HF, Horn JI The reliability of certificates of deaths from cancer. American Journal of Hygiene 1941; 34 (july):12:23

28- Drumond Jr M, Lira MMTA, Freitas M, Nitrini TMV, Shibao K Avaliação da Qualidade das informaçōes de mortalidade por acidentes näo especificados e eventos com intenção indeterminada. Rev Saúde Publica1999; 33(3):273-80.

29- Dunn HL, Enlace de registros. American Journal of Public Health 1946; 36:1412-1416.

30- Durkheim E. El suicidio. Buenos Aires: Schapire;1965.

31- Elias N. La soledad de los moribundos. $2^{\mathrm{a}}$ ed. México:Fondo de Cultura Económica; 1987.

32- Farr W. Mortalidad de los mineros: Una seleccion de los informes y escritos de William Farr, in El desafio de la epidemiologia Problemas y lecturas seleccionadas. Org. Buck C, Llopis A, Nájera E, Terris M. Washington: Organización Panamericana de la Salud /OMS;1988. (OPS - Publicacion Científica, 505)

33- Fonseca LAM, Laurenti R. A qualidade da certificaçăo médica da causa de morte em São Paulo, Brasil. Rev Saúde Publ 1974; 8:21-9.

34- Fortes PAC. Ética e saúde : questőes 6́ticas, deontológicas e legais. Tomada de decisőes. Autonomia e direitos do paciente. Estudos de casos. SP: EPU, 1998.

35- Garcia, JC. La educacion médica en la America Latina.

Washington:OPS, 1972 (Publicación cientifica, 255)

36- Garrucho G, Alunazan M, Madrazo M, Sanchez J, Villalobos H, Infiesta JA. Analisis de la concordancia de los dados recogidos en el certificado medico de defuncion y el boletim estatistico de defuncion. Revista de Sanidad y Higiene Publica 1990; 64(LXIV): 63-72.

37- Gramsci A . Os intelectuais e a organizaçăo da cultura. $7^{\mathrm{a}}$ ed. Rio de Janeiro, Civilização Brasileira, 1989.

38- Gualda DMR et al. Abordagens qualitativas: sua contribuição para a enfermagem. Rev. Esc. Enf. USP 1995; 29:297-309. 
39- Heasman MA, Lipworth L. Accuracy of certification of causes of death general registar office. Studies on medical and population subjects. HSMO 1966; 20.

40- Heckmann LO, Oanani LH, Santanna VC, Bordini O Análise do preenchimento de declarações de óbitos em localidades do Rio Grande do Sul (Brasil). Rev Saúde Pública. 1989, 23(4): 292-297.

41- Hill TP. Treating the dying patient: the challange for medical education. Arch Intern Med 1995,155:1265-9.

42- Houaiss A, Villar MS. Dicionário Houaiss da língua portuguesa. Instituto Antonio Houaiss de Lexicografia e Banco de dados da lingua portuguesa S/C Ltda - RJ: objetiva, 2001.

43- Iyda M. Cem anos de saúde pública: a cidadania negada. SP:Ed.UNESP, 1994

44- Kovács MJ. Pensando a morte e a formação dos profissionais de saúde. In: Cassorla RMS (org): Da morte: estudos brasileiros. Campinas: Papirus, 79103, 1991.

45- Kuller L, Lilienfeld A, Fisher R. Quality of death certificate diagnosis of arteriosclerotic heart disease. Public Health Rep 1967; 82:339-346.

46- Laurenti R, Buchalla CM, Lolio CA, Santo AH, Mello Jorge MH. Mortalidade de mulheres em idade fértil no município de Sāo Paulo (Brasil), 1986. II Mortes por causas maternas. Rev Saúde Pública 1990; 24(6): 468-472.

47- Laurenti R, Jorge MHPM. O Atestado de Óbito. $3^{a}$ ed. Centro da OMS para a classificação de doenças em portugués (Centro Brasileiro de Classificação de Doenças -MS/USP/OPAS/OMS), Núcleo de Estudos em População e Saúde NEPS/USP;1996. (Série Divulgação n¹),

48- Laurenti R, Melo Jorge MHP, Lebrão ML, Gotlieb SLB. Estatísticas de Saúde, São Paulo:EPU, $2^{\mathbb{a}}$ ed.; 1987.

49- Laurenti R, Santo AH, Harada G, Kanniya K, Ishii Y, Osawa Y. Death certificates with mention of neoplasms: comparison of the selection and codification of the underlying cause of death between coders from Tokio (Japan) and Săo Paulo (Brazil). World Health Organization. Meeting of Heads of WHO Collaborating Center for the Classification of Diseases. Beijing, 1992.(SES/IOD/O/92.6).

50- Laurenti R. A Análise da Mortalidade por Causa Básica e por Causas Múltiplas. Rev Saúde Pública 1974; 8: 421435. 
51- Laurenti R. Accuracy of cause of death statements on death certicates and the international comparability of the mortality statistic. Mimeo, 1999.

52- Lefrève $F$, Lefrève AMC, Teixeira JJV, organizadores. O discurso do sujeito coletivo: uma nova abordagem metodológica em pesquisa qualitativa. Caxias do Sul: EDUSC, 2000.

53- Machado R, Loureiro A, Luz R, Muricy K. Danação da Norma: a medicina social e constituiçăo da psiquiatria no Brasil. RJ: Ediçőes Graal, 1978.

54- Marcus PAF, Vega CEP, Boyaciyan K, Barbosa SA. Estudo da mortalidade materna no município de São Paulo durante o ano de 1995. Rev bras ginecol. Obstet out.1996; 18(9):731-6.

55- Meleiro AMAS. O médico como paciente. São Paulo: Lemos- Editorial, 2001.

56- Mello Jorge MHP, Gotlieb SLD. O Sistema de Informaçăo em Mortalidade : problemas e propostas para seu enfrentamento. [Mimeo]. São Paulo; 1998. [Projeto de Pesquisa enviado ao CNPq, MS e FAPESP; em andamento].

57- Mello Jorge MHP. Registro dos eventos vitais: sua importância em saúde pública. Centro Brasileiro de Classificação de Doenças/OMS; 1983.(série divulgação n5)

58- Mello Jorge MHP. Situação atual das estatísticas oficiais relativas à mortalidade por causas externas. Rev de Saúde públ. 1990; 24(3):217-223.

59- Mendes A. A simbologia da morte humana. Rev Oxidologia jun/ago 1999.

60- Mendonça EF, Goulart EMA, Machado JAD. Confiabilidade da declaração de causa básica de mortes infantis em região metropolitana do sudeste do Brasil. Rov Saúde Pública 1994, 28(5):385-91.

61- Minayo MCS. O desafio do conhecimento: pesquisa qualitativa em saúde. 6.ed. São Paulo - Rio de Janeiro: Hucitec, Abrasco, 1999.

62- Minayo, M C S. A Prática Médica sob julgamento ou as potencialidades da crise. R. Bras.Educ. Méd. 1993 set/dez; 17(3):1-44.

63- Ministério da Saúde. Fundação Nacional de Saúde. Guia Brasileiro de Vigilância Epidemiológica. $5^{\mathrm{a} e d}$. Ver. ampl. Cap3: Sistema de Informação em Saúde a Vigiláncia Epidemiológica, 1998. 
64- Ministério da Saúde. Manual de instruçőes para o preenchimento da Declaração de Óbito. Normas e Manuais Técnicos. Brasília. Centro de documentação, 1985.

65- Moraes IHS. Informaçס̋es em Saúde. Da prática fragmentada ao exercício da cidadania. São Paulo-Rio de Janeiro:Ed. Hucitec, Abrasco, 1994.

66- Moriyama IM, Baum WS, Haenszel WM, Mattison BF. Inquiry into diagnostic evidence supporting medical certifications of death. Am J Public Health 1958; 48:1376-1387.

67- Moriyama IM, Loy RM, Robb-Smith AHT. History of nomenclature of diseases, the international classification diseases and the classification of causes of death. Monography, 1994. Washington, DC

68- Muñoz DR, Segre M, Almeida M. Normas práticas para o fornecimento de atestado de óbito. Arq.med.ABC 1984; 7(1-2):19-21.

69- Nascimento A.O Centenário da Academia Nacional de Medicina do Rio de Janeiro 1929; 222-223.

70- Niobey FML, Cascão AM, Duchiade MP and Sabroza PC. Qualidade do preenchimento de atestados de óbito de menores de um ano na regiāo metropolitana do Rio de Janeiro. Rev Saúde Pública 1990; 24(4): 311-318.

71- Nobre LC, Victora CG, Barros FC, Lombardi, Teixeira AM, Fuchs SC. Avaliação da qualidade de informação sobre a causa básica de óbitos infantis no Rio Grande do Sul (Brasil). Rev Saúde Pública 1989, 23(3):207-213.

72- Oficina Sanitaria Panamericana. Oficina Regional de la OMS. El desafio de la epidemiologia : problemas y lecturas seleccionadas, org Buck $C_{\text {, }}$ Llopis A, Nájera E, Terris M. Washington; 1988 (publicacion científica, 505)

73- Oliveira AC, Fortes PAC. O direito à informação de idosos hospitalizados. Anais, VIII Congresso Brasileiro de Saúde Coletiva, Águas de Lindóia/SP, 1995.

74- Oliveira E. Obituário geral durante o ano de 1899 na cidade da Bahia. Gazeta médica da Bahia 1898-1899; 30:355-61, 417-20, 471-5.

75- Paes NA, Albuquerque MEE. Avaliação da qualidade dos dados populacionais e cobertura dos registros de óbito para as regiőes brasileiras.

Rev Saúde publ. 1999; 33(1):33-43. 
76- Paim, J S. A reforma sanitária e os modelos assistenciais: a epidemiologia na organização dos serviços de saúde. In: Lima e Costa M F, Souza, R P (org). Qualidade de Vida: Compromisso histórico da epidemiologia BH: ed. Coopmed - Abrasco, 1994.

77- Paim JS. Abordagens teórico - conceituais em estudos de condiçōes de vida e saúde: notas para reflexão e açăo. In: Condiçð̋es de vida e situaçăo de saúde. (org.) Barata RB. Rio de Janeiro: ABRASCO, 1997.

78- Paula AMC, Evangelista Filho D, Pereira IPA, Albano AHBL, Fernandes RM. Avaliação dos dados de mortalidade, Brasil- 1979 a 1989. Informe Epidemiológico do SUS. Jan/fev/mar; 1994.

79- Pereira MG \& Castro ES, 1981. Avaliação do preenchimento de declaraçōes de óbitos: Brasília, DF ( Brasil), 1977 - 1978. Rev. Saúde púbI, 5:14-19.

80- Pitta A. Hospital: dor e morte como oficio. São Paulo:Editora Hucitec; 1990.

81- Pohlen K, Emerson H. Erros in Clinical Statements of causes of Death. American Journal of Public Health 1942; 32:251 -259.

82- Prado Jr C. Formaçăo do Brasil contemporåneo: colónia. São Paulo: Brasiliense. Publifolha; 2000. P.25-45 (grandes nomes do pensamento brasileiro)

83- Puech LR. Atestados de óbito. Anais Paul. Med. Cirurgia 1919; 277-83.

84- Puffer RR, Griffith GW. Patterns of urban mortality. Washington (D.C): Pan American Health Organization;1967. (Scientific Publication, 151).

85- Puffer RR, Serrano CV. Patterns of mortality in childhood. Washington (DC): Pan America Health Organization; 1973 (Scientific Publication, 262).

86- Reis JJ. O cotidiano da morte no Brasil renascentista. In: Novais AF, coordenador, Alencastro LF, organizador. História da Vida Privada no Brasil: Império. São Paulo: Companhia das Letras; 1997. P.96-141.

87- Rezende C. O suicídio no Rio de Janeiro. Brasil Médico 1908; 22:432-6, 444-7, 454-8.

88- Rocha I. A via urbana. Brasil Médico 1901; 15:176-7.

89- Rojas CM. Calidad de la certificacion y de la codificacion de la causa de muerte. Estado Falcon, 1986. Cuadernos de la Escuela de Salud Publica. 1987; 49: 57-74. 
90- Rosa CAP. A morte e o ensino médico. Rev Brasileira de Educacăo Médica 1999; 23(2/3) maio/dez.

91- Rosauro MW. Morte e formação médica. In: Chiatonne HBC, Andreis M eds Anais do Simpósio: Os limites da vida. 20/11/93 Santa Casa de Misericórdia de São Paulo, 1994: p.1-2.

92- Rosen, G. Da polícia médica à medicina social. Rio de Janeiro: Ediçőes Graal; 1979.

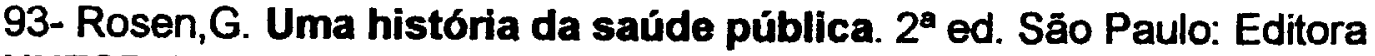
UNESP, Rio de Janeiro: HUCITEC; 1994.

94- Rothman KJ. Lessons from John Graunt. Lancet 1996; 347:37-39.

95- Savater F. As perguntas da vida. SP: Martins Fontes; 2001.

96- Sayd J D. A escola médica e seus implícitos sobre a morte. R.Bras.Educ. Méd. 1993 set/dez:;17(3): 1-44.

97- Schinitman A.Análise da fidedignidade da causa de morte por cáncer em Salvador, Brasil. Rev Saúde públ 1990;19:811-815.

98- Schraiber, L B. Educação Médica : um estudo das relaçoes educaçảo o prática médica na ordem social capitalista. SP - RJ : Ed. Hucitec ABRASC0;1989.

99- Schraiber, L B.O médico e seu trabalho: limites da liberdade. SP - RJ : Ed. Hucitec;1989.

100- Seabra A. Verificação de óbitos. Revista Médica de Såo Paulo 1904; 357-368.

101- Sellers, AH. The Physician's statement of cause of death. Amer J publ Hth 1938; 28:430-4.

102- Siqueira AAF, Rio BEM, Tanaka ACDA, Schor N, Alvarenga ATA, Almeida CL. Mortalidade feminina na região sul do município de Săo Paulo: Qualidade da certificação médica dos óbitos. Rev Saúde públ 1999; 33 (5):499-509.

103- Siqueira J E. Tecnologia e medicina entre encontros e desencontros. Bioética Rev CFM. Vol.8 n 1. Brasilia; 65-67; 2000.

104- Souza L. Assistência aos mortos. Gazeta Clínica jan.1920; 18;1-2. 
105- Souza, L. Verificação de óbitos. Gazeta Clinica fev.1921; 19:11-12.

106- Souza, L. Verificação de óbitos. Gazeta Clínica jan. 1916; 14:1-3.

107- Swartout H O; Webster RG. To what degree are mortality statistcs depndaple? American Joumal of Public Health 1940; 30:811-815.

108- Torres L. Direito, Moral e deveres do médico. Rev. Bras. Cirurg. 71:229$38,1991$.

109- Torres T. Atestados de óbito. Anais Acad. Med. Rio de Janeiro. 105-109; 1912.

110-Udelsman A . Cipoal Jurídico ameaça atendimento. Jomal da APM ed n०529, p.25 out 2002.

111- Vianna A, Picceli $H$. O estudante, o médico e o professor de medicina perante a morte e o paciente Terminal. Rev. Ass. Med. 1998; 44(1):21-7.

112- Weber BT. As artes de curar : medicina, religiăo, magia e positivismo na República Rio Grandense - 1889/1928. Santa Maria: Ed. UFMS;

Bauru:EDUSC, 1999.

113-Wells HG. Relation of clinical to necropsy diagnosis in cancer and value of existing cancer statistic. The Journal of the American Medical Association 1923; 86(11):737-740.

114- Wells R. Experiences whith the international classification of disease and emerging problems, In :Intemational Conference on Health statistic for the year 2000. Pg 18-33, Jointly sponsored by the Rockefeller Foundation and OMS, Statistical Publishing House, Budapest, 1984.

115- World Health Organization. tradução- Centro Colaborador da Organização Mundial de Saúde para a Classificaçäo de Doenças em Portugués.

Classificaçăo Estatística Intemacional de Doenças e Problemas

Relacionados ả Saúde.4a ed. $10^{a}$ revisão; São Paulo: Edusp; 1998. 


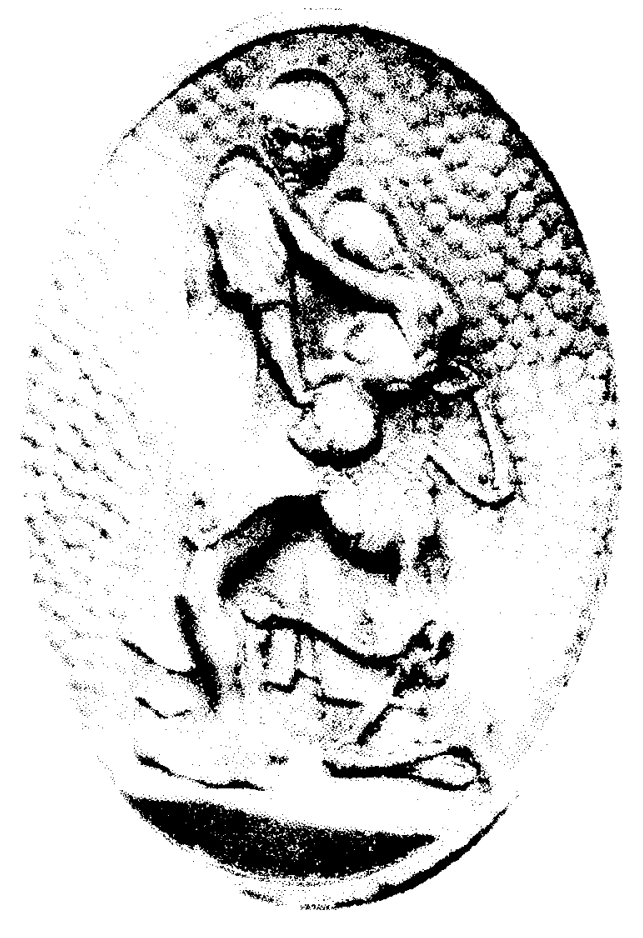




\section{ANEXOS:}




\section{ANEXO I}




\section{Ministério da Saude}

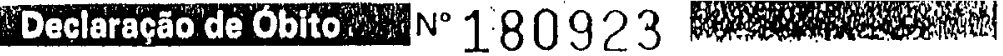

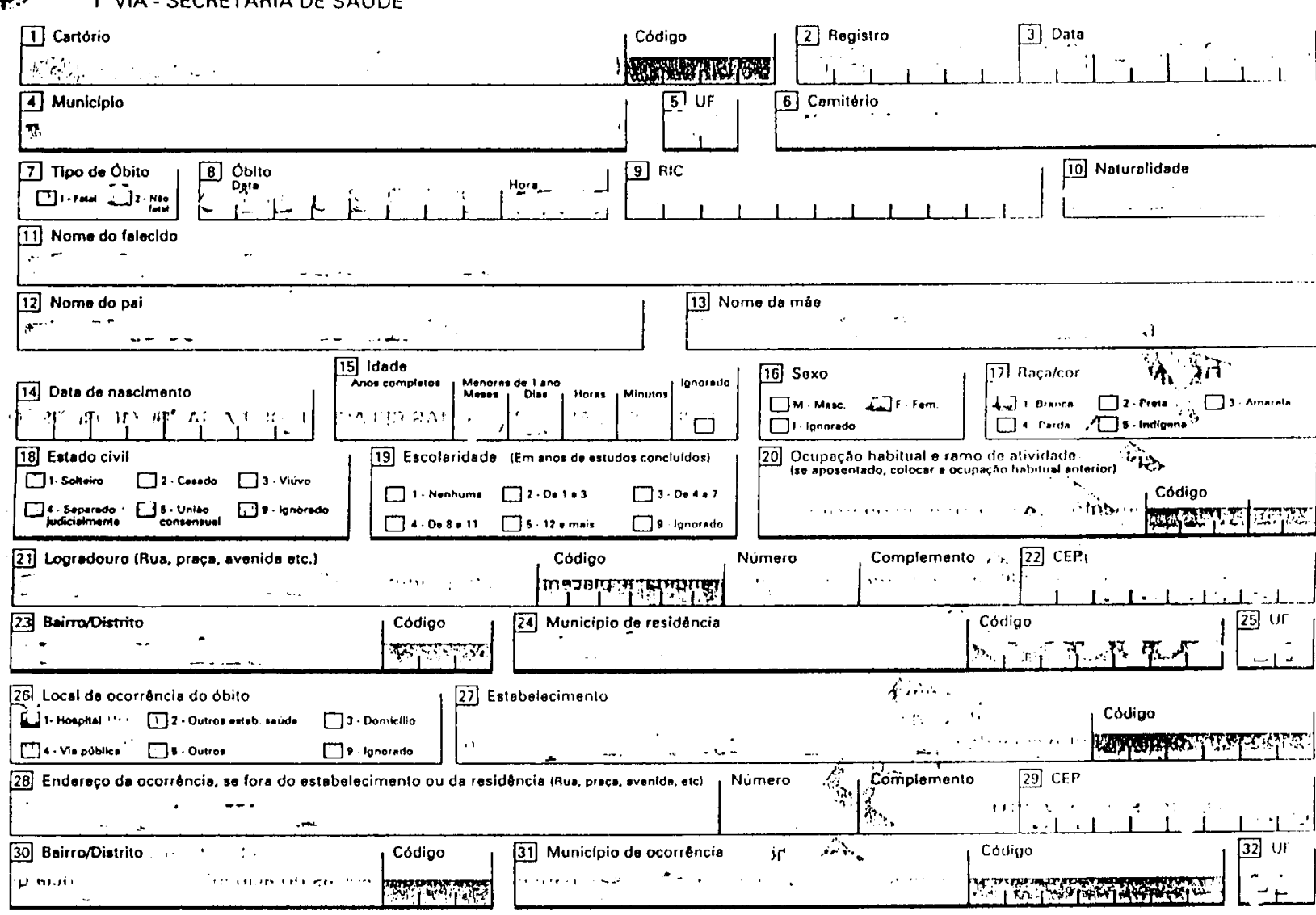

PREENCHIMENTO EXCLUSIVO PARA OBTTOS FETAIS E DE MENORES DE 1 ANO INFORMACYOES SOBRE A MAE

33] Idede .. 34 Escoloridade (Em anos de estudo concluidos)

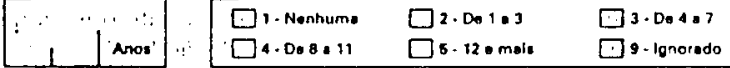

37 Duraço da gestaçho (Em semanas) 38 Tipo de Gravldez 39 Tipo de parto 口. Menoe de $22 \quad \square 2 \cdot 0,22=27$

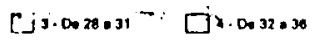

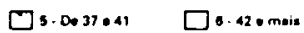

[] - ronorodo OBITOS EM MULHERES

(35) Ocupaçă habilual e ramo de atividade da màc

\begin{tabular}{|c|c|}
\hline 38 Tipo de Gravldez & 39 Tipo de parto \\
\hline Qi. Unice & {$[$ 1. vaginal } \\
\hline$\square$ 2.Dugn & [i, contreo \\
\hline$\square$ J.Tilpia e mals & \\
\hline$\square 9$. Ignornith & $\square$ 9. lorionention \\
\hline
\end{tabular}

$\square$ 9.Imnomin $\square$ a. Iorionanto

3) A morte ocorrou durante a grevidez, parto ou aborto? 44 A morle, ocorreu ducante o puorperior
[1. $\operatorname{sim} \square 2 . \mathrm{NhO}$
$\square \cdot$. Ignoredo
$\square \cdot \operatorname{sim} 01642$ dies

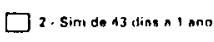
$\square$ - Nato
$\square$ 9. I Inoindo

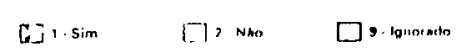

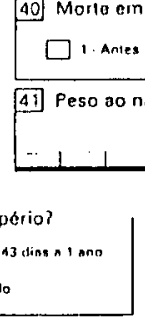

Cotligo

Gonp

36] Número de fillos ticlos

DIAGNÓSTICO CONFRMADO POR:

46] Exome complementer?
47] Cirurgia?

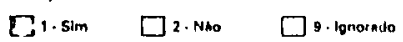

no parto

\begin{tabular}{|c|c|}
\hline $\begin{array}{l}\text { Nascidos } \\
\text { vivos }\end{array}$ & $\begin{array}{l}\text { Nasciftes } \\
\text { tmortos }\end{array}$ \\
\hline
\end{tabular}

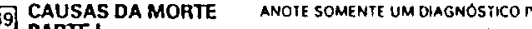
PARTEI

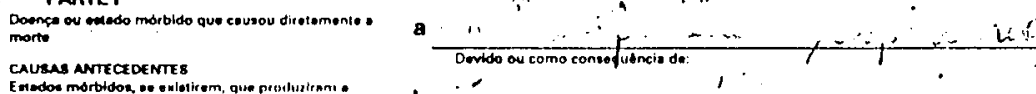

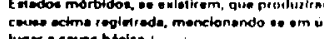$$
\text { . }
$$

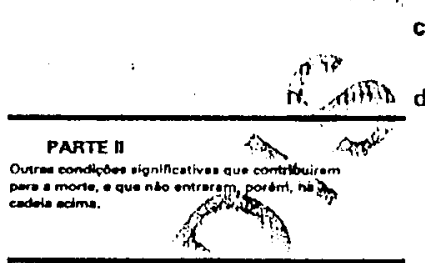

$$
5
$$

53 Meio de contato (Tolafone, fax, a.mgil erci

$1 \cdots$

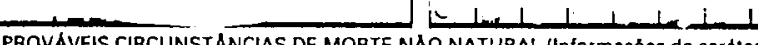$$
56 \text { Tipo }
$$$$
50
$$

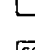

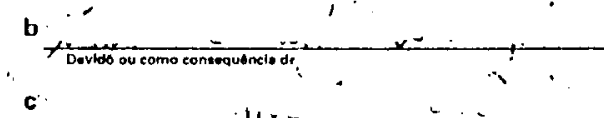

ASSISTENCIA MEDICA

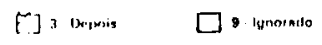

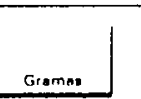

[12] Nurn. da Declar. de Noscidos Vivus

45 Recebeu assist. médica duramut il tloença que ocasionou a mentu?

48 Nerrópsia?

(B)

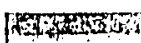

[x]

52 O módico que assina atondou ao talecido?

55 Asspinatura 


\section{ROTEIRO DE ENTREVISTA}

Parte I-

Identificação:

Idade:

Sexo

Tempo de formado

Especialidade

Parte II -

1- Como você se sente afetivamente preenchendo uma DO? Como é isto para você?

2- Onde você aprendeu a preencher atestado de óbito? Conta como foi isto?

3- Vocè tem uma rotina de trabalho, não é? Preencher a Do faz parte desta rotina, não é? Esta rotina facilita ou dificulta o preenchimento do atestado de óbito? Fale um pouco sobre isto.

4- $O$ atestado de óbito é um documento legal, não é? Isto traz algumas conseqüências. Esta é uma coisa que preocupa você, ou não? Fale um pouco sobre isto.

5- A seu ver para que serve uma DO? 


\section{ANEXO III}


F2. Formulário para coleta de INFORMaÇão SObre óbTtos EM DOMICílIO (para causas mal definidas, residuais dos capítulos e presumíveis)

Para preenchimento em nível central

\begin{tabular}{|l|l|}
\hline Nome & Sexo __ Idade ___ Local da morte___ \\
Data da morte __ & \\
Endereço (res) & \\
Cemitério & \\
\hline
\end{tabular}

\section{Para o início da entrevista, ver instrutivo}

Para preenchimento em domicilio

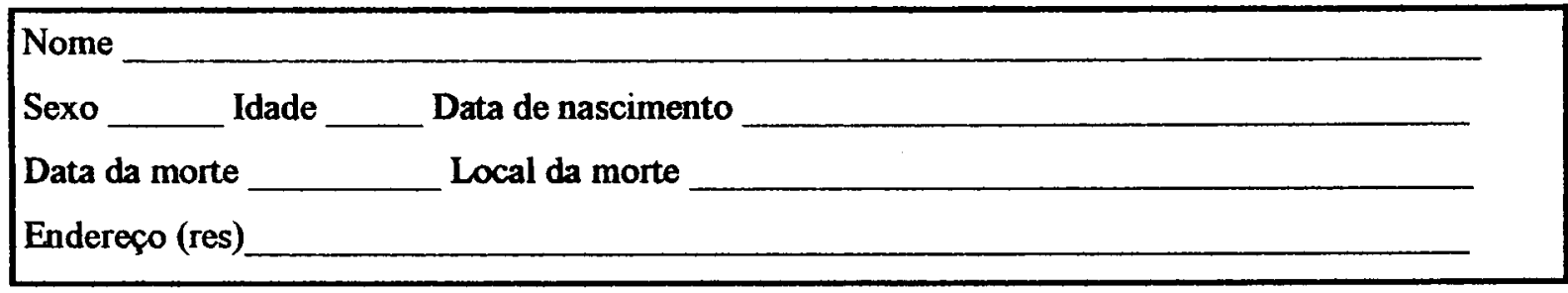

Durante o ano que passou (um ano antes da morte), ... foi atendido por médico, hospital ou Posto de Saúde? $\quad \operatorname{Sim} \square \quad$ Não $\square \quad$ Ignora $\square$

Se Sim, preencha o quadro abaixo

\begin{tabular}{l|l|l|l|l|l|l|}
\hline $\begin{array}{c}\text { Nome do hospital, clínica, } \\
\text { médico, etc. }\end{array}$ & $*$ & Data & $\begin{array}{c}\text { Dias no } \\
\text { hospital }\end{array}$ & Motivo & $* *$ & $* * *$ \\
\hline 1$)$ & & & & & & \\
$2)$ & & & & & & \\
$3)$ & & & & & & \\
\hline
\end{tabular}

* Tipo: $\quad \mathbf{M}=$ médico particular, convênio $\mathbf{H}$ = hospital PS = Posto de Saúde, Centro de Saúde

** Número de consultas

*** Esses atendimentos tinham algo a ver com a doença que levou à morte? $\mathrm{S}=\mathrm{SIM} \quad \mathrm{N}=\mathrm{NÃO}$

- Se mulher entre 10 e 49 anos:

Estava grávida no momento da morte? Sim $\square \quad$ Não $\square \quad$ Ignora $\square$

Se sim, duração da gestação: meses

Esteve grávida nos 12 meses que precederam a morte? Sim $\square \quad$ Não $\square \quad$ Ignora $\square$

Se sim, o produto foi ?

$\square$ Nascido vivo $\square$ Nascido morto $\square$ Aborto $\square$ Ignorado 
Onde foi atendida?

Data

Condições da mãe no momento da alta

Vamos falar um pouco sobre a doença que levou à morte

- Como começou a doença

- Descrição da doença (detalhar)

Se se tratar de acidente/violência, detalhar ao máximo o tipo de acidente e o tipo de lesão.

- Quanto tempo ficou doente?

Fez tratamento caseiro? Sim $\square \quad$ Não $\square$ Ignora $\square$ Qual?

- Teve assistência médica? Sim $\square \quad$ Não $\square$ Ignora $\square$ Se sim, onde?

Endereço

- E o que mais foi feito?

- Tomou remédio? Sim $\square \quad$ Não $\square \quad$ Ignora $\square \quad$ Se sim, qual?

- Que doença levou à morte?

- Onde morreu? Domicílio $\square$ Hospital $\square$ Ignora $\square \quad$ Outro lugar $\square$

Se hospital, qual e onde?

- A Sra. acha que essa morte poderia ter sido evitada?

Se sim, como?

Data _ I I I Entrevistador

CONCLUSÃO

Encaminhamento: Fazer outro formulário? Sim $\square \quad$ Não $\square$

Se sim, qual? 


\section{F3. FORMULÁRIO PARA COLETA DE INFORMACÕES HOSPITALARES SOBRE ÓBITOS (causas mal definidas, residuais dos capítulos e presumíveis)}

Para preenchimento em nível central

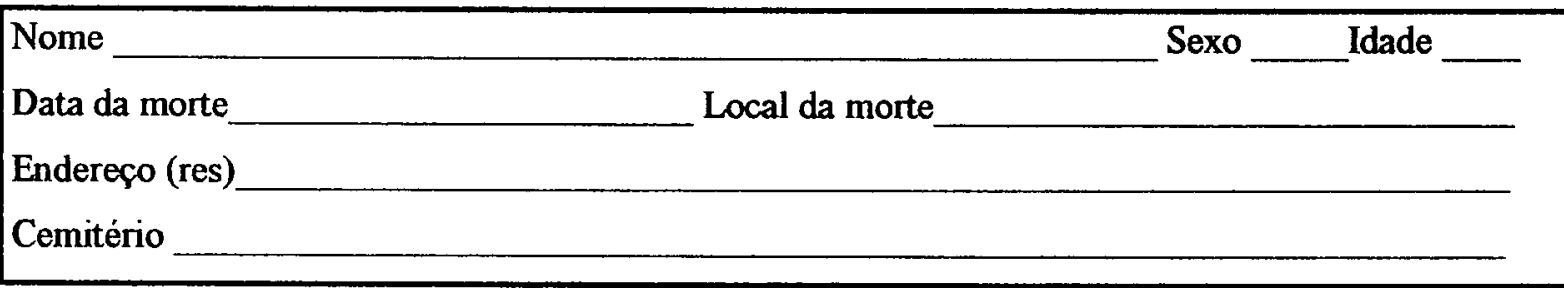

Para o inicio da entrevista, ver instrutivo

Para preenchimento no hospital

Nome
Sexo $\_$Idade $\_$Data de nascimento
Data da morte
Endereço (res)

Data de entrada no hospital Data de saída

Condições do paciente à admissão

Resumo da anamnese (sintomas)

Resumo da evolução do paciente

\section{Exames}

a) Laboratório

\begin{tabular}{|l|l|l|}
\hline Tipo & Data & Resultado \\
\hline & & \\
& & \\
\hline
\end{tabular}


b) Raio $X$

\begin{tabular}{|l|l|l|}
\hline Tipo & Data & Resultado \\
\hline & & \\
& & \\
\hline
\end{tabular}

c) Citologia/biópsia (descrever o material e resultado)

d) Operações e achados

\begin{tabular}{|l|l|l|}
\hline Tipo & Data & Resultado \\
\hline & & \\
& & \\
\hline
\end{tabular}

e) Diagnósticos clínicos

f) Autópsia ? Sim $\square$ Não $\square$ Resultado:

Para óbitos femininos de 10 a 49 anos, verificar se consta informação sobre a presença de gravidez, parto e puerpério nos 12 meses que precederam a morte.

- Se mulher entre 10 e 49 anos:

Estava grávida no momento da morte? $\operatorname{Sim} \square \quad$ Não $\square \quad$ Ignora $\square$

Se sim, duração da gestação: meses

Esteve grávida nos 12 meses que precederam a morte? $\operatorname{Sim} \square \quad$ Não $\square \quad$ Ignora $\square$ Se sim, o produto foi ?

$\square$ Nascido vivo $\square$ Nascido morto $\square$ Aborto $\square$ Ignorado

Onde foi atendida? Data

Condições da mãe momento da alta

\section{DADOS SOBRE O ÓBITO:}

O que consta no Prontuário:

Data 1 ___ Entrevistador

\section{CONCLUSÃO}

Encaminhamento: Fazer outro formulário? Sim $\square \quad$ Não $\square$ Se sim, qual? 
F4. FORMULÁRIO PARA COLETA DE INFORMAÇÃo SOBRE ÓBTTOS DOMICILIARES QUE TIVERAM ALGUMA ASSISTÊNCIA MÉDICA ANTERIOR COM MÉDICO, CS, PS OU ASSEMELHADO.

Para preenchimento em nível central

Nome

Sexo

Idade

Data da morte

Local da morte

Endereço (res)

Cemitério

Para o início da entrevista, ver instrutivo

Para preenchimento no local do atendimento

Nome

Sexo Idade Data de nascimento

Data da morte Local da morte

Endereço (res)

1. Houve atendimento a essa pessoa?

$\operatorname{Sim} \square$

Não $\square$

Ignora $\square$

2. Se sim,

Quando?

Quantas vezes?

Qual o diagnóstico?

Houve confirmação por exames complementares?

$\operatorname{Sim} \square$

Não $\square$

Ignora $\square$

Quais?

Qual foi a doença responsável pela morte? Ignora $\square$

Entrevista feita com (anotar nome do médico ou Centro de Saúde que fez o atendimento)

Data Entrevistador 
F5. FORMULÁRIO PARA COLETA de INFORMAÇÃo SOBRE CAUSAS EXTERNAS (IML - DP)

Para preenchimento em nível central

\begin{tabular}{|l|l|}
\hline Nome __ Sexo ___ Idade \\
Data da morte \\
Endereço (res) \\
Cemitério
\end{tabular}

Para o início da entrevista, ver instrutivo

Para preenchimento em instituição

Nome

Sexo Idade Data de nascimento

Data da morte Local da morte

Endereço (res)

\section{INFORMAÇÃO DA DP}

Data do evento Data da morte

Tipo de causa externa (o mais detalhado possível)

OBS

\section{INFORMAÇÃO DO IML}

Data da morte

Natureza da lesão

Tipo de causa externa (descrição do acidente/violência)

OBS

Data Entrevistador 


\section{ANEXO IV}




\section{TERMO DE CONSENTIMENTO, LIVRE E ESCLARECIDO}

Eu,

CRM

estou participando dessa entrevista de livre e espontânea vontade e concordei com a que mesma seja gravada, uma vez que faz parte da metodologia adotada. Fui informado (a) que esta se presta a um trabalho de tese de doutorado que tem como tema, o entendimento que os (as) médicos (as) tem da Declaração de Óbito. Também fui orientado (a) que as informações por mim fornecidas terão tratamento sigiloso e que em nenhum momento serei exposto ou exposta, nominalmente.

Além disso, posso solicitar, a qualquer momento a retirada dessas informações, sem que haja qualquer tipo de represália em relação a minha pessoa.

Acrescento que recebi da autora do projeto o seu cartão de apresentação constando endereço e telefone para contato, caso sinta necessidade.

Marília, de de 2002.

entrevistado

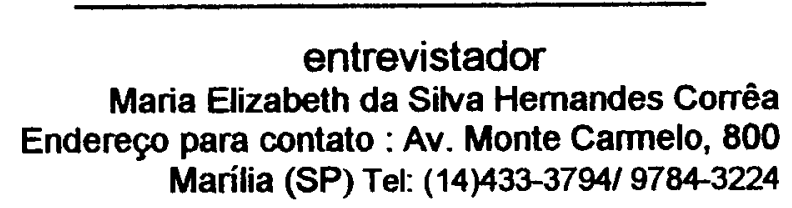




\section{ANEXO V}




\section{1-Como você se sente afetivamente preenchendo uma declaração de óbito? Como é isto para você?}

\begin{tabular}{|c|c|}
\hline Expressão chave & Idéia central \\
\hline 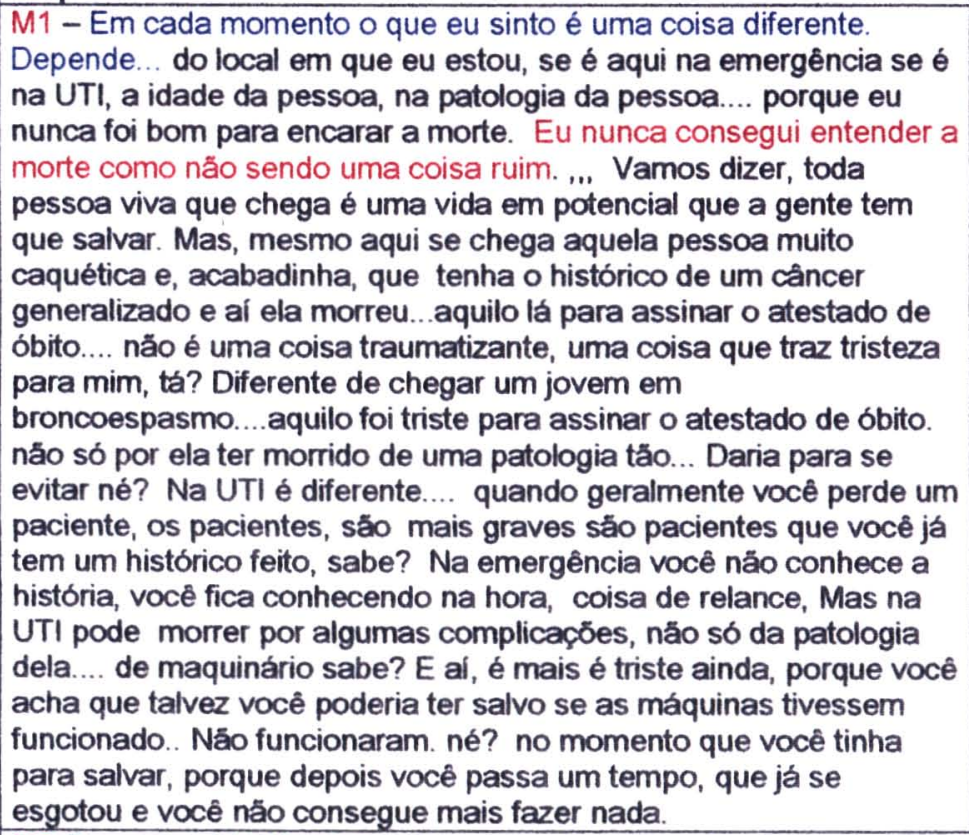 & $\begin{array}{l}1^{\circ} \text { Depende } \\
2^{a} \text { É uma coisa ruim }\end{array}$ \\
\hline $\begin{array}{l}\text { M2-Para mim é indiferente .. Nunca senti nenhum tipo de } \\
\text { sentimento. }\end{array}$ & $E$ indiferente \\
\hline 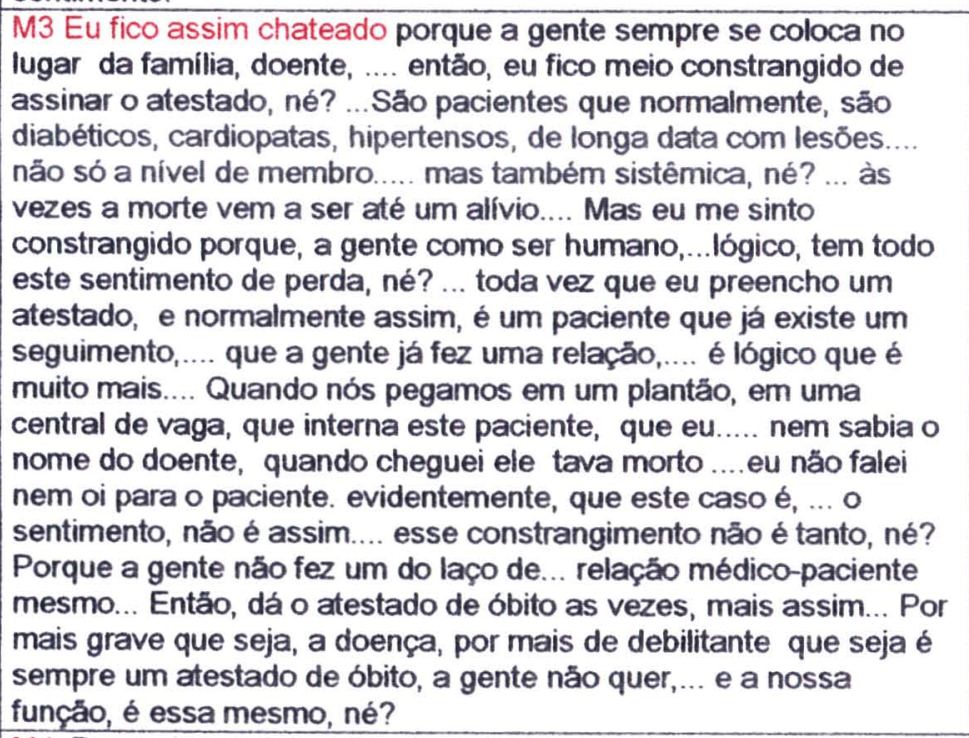 & Fico chateado \\
\hline $\begin{array}{l}\text { M4 Depende, ocasionalmente, você se depara com alguém que } \\
\text { vocé conheceu, ou entăo crianças, e isso a gente fica um pouco } \\
\text { mais constrangido e envolvido, ... Mas na maioria das vezes não } \\
\text { tem nenhum envolvimento emocional por desconhecer } \\
\text { completamente a vítima el ou os familiares. }\end{array}$ & Depende \\
\hline $\begin{array}{l}\text { M5 Olha, eu não tenho nenhum tipo de sentimento. Vamos dizer, } \\
\text { eu... Preencho aquilo como uma coisa natural... que faz parte do }\end{array}$ & Faz parte do trabalho \\
\hline
\end{tabular}


meu trabalho

M6- A gente tá preparado que uma das coisas é assinar o atestado de óbito, por que trabalhar em um hospital com paciente grave cuja mortalidade é extremamente alta, né? .. Entảo, a gente, uma vez feito contato com a família, com as pessoas responsáveis pelo doente, você faz a relaçăo e dá um atestado de acordo com aquilo que você tem de preencher... com as normas de preenchimento do atestado de óbito... sem ter um certo envolvimento emocional a ponto de interferir no bom relacionamento dos contactantes da pessoa que morreu, entendeu? Senão fica complicado.

M7 Acho que não é bom, é ruim. $E$, quando me sinto impotente eu descobri naquela hora que eu năo sou nada... só isso... Me sinto muito mal, assim... m... Tem dois tipos de atestado que eu acho que.. existe para mim. Então, eu tenho o atestado do paciente, quer dizer, que é um velho... o que tem uma doença bern definida em fase terminal, que eu vi que isso para ele.... ele năo vai morrer... eu falo que ele descansa... mas é uma sensaçáo ruim... eu me sinto assim, que apesar de tudo, o que eu fiz na minha vida, o que eu estudei năo serviu para muita coisa, não, eu simplesmente, assim... Eu aprendi a cuidar dele para dar morte com dignidade, só, tá? este é um tipo de atestado; dói , mas.. eu sinto a minha impotência. E o outro atestado, eu acho que é o atestado assim... de uma pessoa que era normal e que de repente é um acidentado este é um ambiente muito ruim de dar atestado, quer dizer é uma pessoa que năo tinha nada... tinha uma vida inteira... acho que este é um doente que é doloroso... Dói bastante... Assim, Näo, porque ele às vezes, já chega em estado de óbito, entăo, eu só vou dar um atestado

M8Olha, para mim é familiar, devido há muitos anos. .... Năo me chama atençăo em nada, acho que é uma obrigação do médico preencher... Também sinto uma tristeza de saber que podia talvez feito alguma coisa por esta pessoa que acabou de falecer.

Antes de ontem chegou uma senhora com um infarto do miocárdio, as 9 e 30 horas conseguimos reverter por duas vezes e na terceira vez após 3 horas e meia fazendo tudo o que se tinha alcance para fazer, ela veio a falecer entăo, nós sentimos sendo pequenininho dentro disto.... Falava que cada paciente... devemos tratar como sendo o nosso pai, sendo nossa măe, sendo nossa irmă, nossos filhos e entăo ... Com isto. Gravei, petrifiquei...na minha mente que o comportamento tem que ser isso. Năo por um sentido de ser gente, năo, mas de uma unidade da composição da própria gente, da tradiçăo da própria família da gente, que se é chegado a uma religiăo e esta religiăo que é a católica, e fez valorizar a vida, a vida de quando nascem, a vida até quando chega falecer, que são princípios que determinam um Deus. E não é bem assim que cada um nasce no dia que tern que nascer e morre no dia que tem que morrer, será que nós médicos podemos fazer alguma coisa, lutando, talvez, lutando na contra máo de Deus de prolongar um pouco mais a vida?

M9 ... Cada caso é um caso, mais assim... No geral, năo sinto nada afetivamente, entendeu? ... porque normalmente os casos assim que mexeriam mais com a gente seriam aqueles casos que văo para o necropsia, tipo assim... Acidentes de gente jovem que morrem aqui né? ....Mas normalmente năo consigo mais, afetivamente, me envolver muito com essa coisa de preenchimento da morte do paciente, năo. ... Quando eu cuidava de paciente internado, eu me envolvia mais, agora, normalmente, é paciente que eu năo criei vínculo. ...Alguns eu criei vínculo, por exemplo: paciente asmático, DPótico que vem continuamente ao prontosocorro ou àqueles cancerosos que vem normalmente ao prontosocorro que no fim ele acaba morrendo aqui, estes aí a gente... o dia que ele morrer nós vamos sentir..., mas a maioria não dá tempo 
da gente... Sei lá..

M10-Depende.. Por se essa paciente é internada, se eu já estou $1^{\text {a }}$ Depende

acompanhando, né? Eu tó vendo, tava bem... Que de repente.. na hora.., dai eu fico um pouco triste. Mas, assim, quando é um paciente que já năo tem prognóstico, ou que chega só para a constataçăo do óbito, normal... É indiferente..

M11- Olha, acho que é assim... Na última residéncia, que foi de oncologia a gente via muito paciente ruim, muito paciente falecido, né? E vocé passa a ver as coisas de um outro jeito, não de uma forma afetiva mas passa a entender a morte como um evento natural, um evento que a gente năo consegue escapar, né? Entăo, assim... Acho que a parte afetiva fica de lado, entendeu? . Os pacientes que sofrem muito a gente até se sente meio aliviado quando eles falecem.

M12 Pergunta complexa.. O que eu aprendi na oncologia é que a gente tem um limite... É uma coisa que a gente nåo aprende na escola. Entåo na oncologia a grande parte dos tratamentos săo paliativos, a finalidade do tratamento paliativo é que vc evite o sofrimento do seu paciente, quando a gente preenche o atestado de óbito normalmente săo pacientes crônicos, săo pacientes que viveram muito tempo com você. ..... Eles acabam tendo um vínculo além do profissionalismo, que muitas vezes você tem que tentar esquecer, tentar ser o profissional o máximo possivel... entáo, é assim... dentro deste contexto que a gente acaba assinando o atestado de óbito. Existem pacientes em que a gente usa o termo de descansar e năo morrer.... tem um outro lado também que ele acaba tendo um certo alivio, ele acaba indo para um lugar melhor, assim diriam alguns.... então, assim... O pesar do atestado de óbito é complicado ..... Entăo, assim... Na oncologia... O médico, ele tem que fazer parte da receita, da mesma forma que vocé prescreve dipirona, 35 gotas, sei lá.... qualquer coisa... Você tem que prescrever o oncologista senão o seu tratamento năo funciona. A relaçăo médico-paciente tem que ser a mais real e transparente possivel, entăo dentro do contexto.. o atestado de óbito a declaraçăo de morte também é transparente. Entăo, assim... É uma perda... É uma perda... Eu encarava na residência o atestado de óbito como uma incapacidade médica,..... Nestes doze ou mais anos de oncologia fiz, refiz, vários conceitos inclusive da própria morte.

M13 ... depende muito do atestado que eu vou assinar, se eu tó de plantăo...chega o paciente que foi a óbito em casa e a ambuláncia traz correndo.., a gente assina como morte sem assistência médica.. Na verdade é indiferente para mim. Assino porque é um dever...agora, alguns pacientes que a gente atende que você cria um vínculo médico-paciente .... aí eu, às vezes, eu fico um pouquinho bastante deprimido, isto me da um pouco de depressăo, sim. A depressão é porque a gente começa filosofar um pouquinho, falar. puxa vida a gente na verdade faz, acha que quando você vai estudar medicina você vai entender como que funciona o pensamento de uma pessoa, você vai entender... Na verdade a medicina năo... Não mostra muito isso dai, e aí vocé vê que você tá sujeito, como esta própria pessoa.. Eu me transfiro muito... Entăo eu fico naquela depressăo, de puxa... Năo ter podido fazer uma coisa a mais, como a gente é limitado, na verdade.

M14 Acho que depende muito do tipo, assim... Da patologia do paciente, né? ...Acho que tudo săo fases... No começo incomodava, hoje năo incomoda mais... Hoje encaro como mais naturalidade mesmo, depende da patologia, agora, você pega uma pessoa jovem, com uma neoplasia como já aconteceu algumas vezes, trinta anos e em fase terminal, vocé se envolve realmente, você sente....... Năo em termos de assinar o atestado de óbito, não, em

termos de perder paciente, né? Uma impotência em termos de não

$1^{\text {a }}$ Incapacidade médica

É uma perda 
resolver a doença daquele paciente, nảo importa a fase que ele esteja, mas o paciente em si em relaçăo ao atestado de óbito, de assinar um atestado de óbito, năo.

M15 Bem eu não me sinto...., mas eu não sei explicar certinho como eu me sinto,... Acho que aqui a gente assina tanto que a gente acaba até tratando de uma forma meio fria, a gente acaba considerando normal, assim... . A gente lê de forma automática... Năo fria, de forma automática e preenche, acho que isso..., às vezes, eu me pego pensando assim " nossa isto aqui... " ... Tá preenchendo lá e pensando, a aí se toca que foi um óbito que reaimente foi ali uma vida, né? Que terminou ai ...de como a gente....pelo serviço... Por trabalhar um monte.. a gente assina muito atestado de óbito acaba não dando a devida importância emocional no caso.

M16 No principio fiquei com bastante medo que colocar, pela queståo jurídica que poderia ter... Mas afetivamente hoje eu năo tenho nenhum problema. É normal.

M17 Năo sinto nada. ... Quer dizer, faz parte no trabalho, é natural, năo tem emoçăo

M18... Inicialmente, quando eu comecei como médico-legista

Quando eu me deparava com a morte sempre era, um pouco deprimente.... mas com o tempo, você... É um trabalhado que você năo se acostuma, mas se habitua um pouco... é um único fato que a gente nảo consegue deixar de, às vezes, se emocionar um pouco é criança, os acidentes com crianças sempre machucam um pouco

M19 Eu, ... ainda doí muito. ....graças a Deus,.... de paciente que eu acompanho por tempo longo ... é dificil eu assinar atestado de óbito. Eu já assinei muito atestado de óbito, na UTI por que eu trabalhei como intensivista, e assim.;.. como eu sou neonatologista... vc é obrigado a assinar de uma criança recémnascida que vai a óbito.... mas o envolvimento da gente com aquela criança ainda é menor. Mas quando vc perde uma criança que vc conhece, que vc conviveu mais... ainda é maior a ... a perda para gente é como se fosse uma perda irreparável... e sp que eu assino AO é uma dor a mais... eu ainda năo assino $A O$ sem doer..

M20 Depende das circunstâncias... Se eu tive um vínculo mais prolongado com o paciente que se eu prestei assistência médica para ele... é ... ora sinto com a missäo cumprida, né?, de Ter feito o que eu pude pelo paciente, ora tem o infortúnio de năo Ter conseguido fazer tudo o que podia e horas que a gente é burocrata, pura e simplesmente, por que vc atende um paciente no sistema público de saúde e o seu objetivo é dar o atestado de óbito...

M21 ... Que eu tenho que estar preenchendo corretamente para pessoa de quem eu cuidei... Depende, quando eu faço verificaçăo de óbito eu nảo tenho. nenhuma, em termos afetivos eu năo sinto nada, né? Porque săo pessoas que eu nảo conheço o as vezes a gente só vê a pasta mas assim termos de pacientes que eu cuidei na enfermaria por exemplo estes eu quero ter muito mais cuidado para preencher porque é às vezes são pacientes que têm seguro e que se tiver preenchido de forma adequada a familia desses pacientes vảo ter dificuldade para conseguir seguro...

M22 Aquele que pega uma certa afetividade, fica mais do que o normal, fica mais de 4 dias, entăo vc tem um envolvimento com a família, com o próprio doente, entăo, eu tenho assim um pouco de pena... Outros năo... eu não sinto nada, quer dizer eu assino o atestado de óbito por que eu sabia que ele entro para morrer năo tinha o que fazer e... é mais uma.. uma obrigaçăo técnica do médico quando o doente morre eu tenho que fazer isto.....cada doente crónico meu que já tá... uma sensaçăo: :que pena que ele foi . muitas das vezes o doente nảo é grave entảo a sensaçăo é: será que eu podia ter feito algo para evitar? E quando eu percebo

Bem eu não me sinto

$2^{a}$ Assina muito, não dá a devida importância

Bastante medo

Faz parte do trabalho

$1^{\mathrm{a}}$ sempre era deprimente

Ainda dói muito

Depende das circunstâncias

Depende

$1^{\mathrm{a}}$ um pouco de pena.

$2^{a}$ eu não sinto nada 


\begin{tabular}{|c|c|}
\hline $\begin{array}{l}\text { M23 É uma coisa assim dura.... Fico pensando... como é que a } \\
\text { familia tá encarando isto ... sensaçăo triste... por que vc não } \\
\text { conseguiu manter a vida deste paciente, o que poderia Ter feito a } \\
\text { mais o que, que eu posso Ter falhado acho que fica sp uma } \\
\text { pergunta deste tipo... }\end{array}$ & É uma coisa assim dura \\
\hline $\begin{array}{l}\text { M24 Depende... quando eu assino AO genericamente, quer dizer eu } \\
\text { tenho meus pacientes da clínica que văo a óbito e tenho os } \\
\text { pacientes do IML que văo a óbito. Evidentemente os pacientes do } \\
\text { IML eles não em nenhum significado afetivo em decorrência...no } \\
\text { momento após a morte, năo tive relacionamento nenhum com este } \\
\text { individuo. Agora, quando é um cliente meu que vai a óbito em } \\
\text { decorrência de patologia ou intercorrência ou qualquer motivo, aí } \\
\text { realmente a gente tem um despertar afetivo...... }\end{array}$ & Depende \\
\hline $\begin{array}{l}\text { M25 Como meus óbitos săo de pacientes conhecidos, } \\
\text { habitualmente crônicos, portanto, de longa convivência, } \\
\text { normalmente é uma sensação de perda .... é uma sensaçăo aonde } \\
\text { vc questiona, se vc fez todo possivel por aquele paciente, se vc } \\
\text { poderia Ter tido estratégias terapéuticas diferentes daquela que vc } \\
\text { assumiu... pq na verdade o óbito tem um valor qualitativo no seu } \\
\text { trabalho então há necessidade de vc tá analisando sp. No momento } \\
\text { de vc assinar o AO todas estas coisas acontecem. }\end{array}$ & $1^{\text {a }}$ é uma sensação de perda .... \\
\hline
\end{tabular}

Nota : cada cor destaca uma idéia central diferente.

Separaram -se as idéias-centrais semelhantes, elaborando uma síntese, vide quadro seguinte. 


\section{Pergunta 1}

Como você se sente afetivamente preenchendo uma declaração de óbito? Como é isto para você?

\begin{tabular}{|c|c|}
\hline Expressão chave & Idéia central \\
\hline $\begin{array}{l}\text { M2-Para mim é indiferente .. Nunca senti nenhum tipo de } \\
\text { sentimento. }\end{array}$ & $\begin{array}{l}\text { Nunca senti nenhum tipo de } \\
\text { sentimento }\end{array}$ \\
\hline $\begin{array}{l}\text { M5 Olha, eu não tenho nenhum tipo de sentimento. Vamos } \\
\text { dizer, eu... Preencho aquilo como uma coisa natural... que } \\
\text { faz parte do meu trabalho... }\end{array}$ & Faz parte do trabalho \\
\hline $\begin{array}{l}\text { M6- A gente tá preparado que uma das coisas é assinar o } \\
\text { atestado de óbito, por que trabalhar em um hospital com } \\
\text { paciente grave cuja mortalidade é extremamente alta, né? .. } \\
\text { Entāo, a gente, uma vez feito contato com a familia, com as } \\
\text { pessoas responsáveis pelo doente, você faz a relaçăo e dá } \\
\text { um atestado de acordo com aquilo que você tem de } \\
\text { preencher... com as normas de preenchimento do atestado } \\
\text { de óbito... sem ter um certo envolvimento emocional a ponto } \\
\text { de interferir no bom relacionamento dos contactantes da } \\
\text { pessoa que morreu, entendeu? Senăo fica complicado. }\end{array}$ & Faz parte do trabalho \\
\hline $\begin{array}{l}\text { M8Olha, para mim é familiar, devido há muitos anos. .... Năo } \\
\text { me chama atençăo em nada, acho que é uma obrigaçäo do } \\
\text { médico preencher.... Tambem sinto uma tristeza de saber } \\
\text { que podia talvez feito alguma coisa por esta pessoa que } \\
\text { acabou de falecer. }\end{array}$ & É uma obrigação do médico \\
\hline $\begin{array}{l}\text { M11 Olha, acho que é assim... Na última residência, que foi } \\
\text { de oncologia a gente via muito paciente ruim, muito paciente } \\
\text { falecido, né? E você passa a ver as coisas de um outro jeito, } \\
\text { năo de uma forma afetiva mas passa a entender a morte } \\
\text { como um evento natural, um evento que a gente não } \\
\text { consegue escapar, né? Então, assim... Acho que a parte } \\
\text { afetiva fica de lado, entendeu?. Os pacientes que sofrem } \\
\text { muito a gente até se sente meio aliviado quando eles } \\
\text { falecem... }\end{array}$ & A morte é um evento natural \\
\hline $\begin{array}{l}\text { M17 Não sinto nada. .... Quer dizer, faz parte no trabalho, é } \\
\text { natural, năo tem emoçăo }\end{array}$ & Faz parte do trabalho \\
\hline $\begin{array}{l}\text { M22 E mais uma... uma obrigaçăo técnica do médico } \\
\text { quando o doente morre eu tenho que fazer isto..... }\end{array}$ & É uma obrigação técnica \\
\hline
\end{tabular}

\section{A $1^{\mathrm{a}} \mathrm{IC}$ elaborada apresentou a seguinte sintese:}

"Preencher o AO faz parte do trabalho médico, é uma atividade técnica e uma obrigação, porisso não há nenhum sentimento envolvido, mesmo porque a morte é um evento natural." 


\section{IAD2}

IC1: Preencher o AO faz parte do trabalho médico, é uma atividade técnica e uma obrigação, porisso não há nenhum sentimento envolvido, mesmo porque a morte é um evento natural.



